\title{
LA CRISIS DEL IDEARIO REPUBLICANO DE DERECHOS EN LOS ESTATUTOS DE AUTONOMÍA
}

\section{THE CRISIS OF THE RIGHTS' REPUBLICAN CONCEPT IN THE AUTONOMY STATUTES}

\author{
Enrique Álvarez Cora \\ Universidad de Murcia
}

\begin{abstract}
SUMARIO: I. INDIVIDUALIDAD NATURAL DE LOS DERECHOS EN EL IUSNATURALISMO RACIONALISTA. - II. PRINCIPIO DE IGUALDAD, UNIDAD Y HORIZONTALIDAD DE LOS DERECHOS INDIVIDUALES. - III. DESNATURALIZACIÓN Y LEGALIZACIÓN DE LOS DERECHOS INDIVIDUALES CONSTITUCIONALES. - IV. DESINDIVIDUALIZACIÓN Y DERECHOS COLECTIVOS SOCIALES. - V. DESINDIVIDUALIZACIÓN Y DERECHOS COLECTIVOS NACIONALES. - VI. AUTONOMÍA REGIONAL, GARANTÍAS INDIVIDUALES Y DERECHOS SOCIALES EN LA II REPÚBLICA. - VII. LA CONSTITUCIÓN DE 1978 Y LA POLINACIONALIZACIÓN DE LOS DERECHOS PROVINCIALES HISTÓRICOS. - VIII. CRÍTICA DE LA DOCTRINA JURÍDICA DE LOS DERECHOS HISTÓRICOS. - IX. VISIÓN CONSTITUCIONAL Y ESTATUTARIA DE LOS DERECHOS FUNDAMENTALES.
\end{abstract}

Resumen: Este trabajo estudia el concepto de los derechos individuales en el constitucionalismo español, destacando la evolución de los rasgos de su concepción original racionalista, así como el resultado de su contraste con la aparición de los derechos colectivos de carácter social o nacional, estatal o regional, para analizar por último en qué medida la configuración de las identidades históricas en los Estatutos de Autonomía puede absorber o limitar el respeto de los derechos individuales.

Abstract: This paper studies the concept of the individual rights in the Spanish constitutionalism, by emphasising the evolution of its racionalistic and original conception's characteristics, as well as the outcome of its contrast with the appearance of the colective rights with social or national, state or local rights, to analyse finally in what measure the historical identities in the Autonomy Statutes' configuration can absorb or restrict the respect of the individual rights.

Palabras clave: Derechos individuales. - Derechos sociales. - Derechos nacionales. - Autonomía.

Key words: Individual rights. - Social rights. - National rights. - Autonomy. 


\section{INDIVIDUALIDAD NATURAL DE LOS DERECHOS EN EL IUSNATURALISMO RACIONALISTA.}

Puede comenzar este trabajo con una obviedad ${ }^{1}$ : el constitucionalismo español vuelca el cuerpo político del absolutismo moderno germinado en un iusnaturalismo de nuevo cuño y raíz protestante, el racionalista, elaborado desde la segunda mitad del siglo XVII con una teoría político-jurídica de los derechos individuales que se postuló enfrentada a los privilegios estamentales inherentes al iusnaturalismo teológico. En efecto, esto es bien sabido. Los derechos individuales se enfrentaron así a la singularidad de los privilegios porque convidaron, desde su igualdad racional, a la primacía de la ley, esto es, a la eficacia igual de una norma de carácter general (no contraria a la especialidad pero sí a la ratio singularis), no obstante esta ley que los derechos individuales conjuraron no fue ya la ley general del ius regium sino la que obedecía a la voluntad general como facultad predicada de un nuevo sujeto político activo, la ciudadanía, en orden a la construcción de un solo Estado, y motor por titularidad de la soberanía y representación en el procedimiento de elaboración del Derecho positivo $^{2}$.

Hay que entender, sin embargo, que la energía de los derechos individuales no terminaba reducida al servicio de una determinada causa (democrática) de arquitectura institucional ${ }^{3}$, sino que además se sustanciaba en el hecho de que, formulados en cuanto tales derechos individuales y gracias al antagónico contexto institucional absolutista en el que brotó su ideario, aquilataron una naturaleza o esencia propia para resguardarse de toda dependencia de las estructuras institucionales políticas o de la tramoya de la mecánica legislativa. Cupo así una cierta flexibilidad teórica en la acomodación política estructural de los derechos individuales, tanto una hipótesis moderada que los vinculase a determinadas formas organizativas (v. gr. con el rey como cabeza del poder ejecutivo, más sancionador y promulgador de la ley, aun con derecho de veto, como será propio del constitucionalismo moderado y conservador) cuanto, conforme a otra sensibilidad racionalista alternativa de aliento anarcoide, la ponderación de todo sistema jurídico como un factor secundario, subvertible y siempre subordinado a la preeminencia, fundadora y teleológica, de aquellos derechos de los individuos.

1 Este estudio pertenece al Proyecto de Investigación titulado La responsabilidad juridica en la Europa moderna y contemporánea (siglos XV-XX), ref. 20787/PI/18, financiado por la Fundación Séneca.

2 Para una concreta y bien perfilada comprensión de la noción de voluntad general en el constitucionalismo, Ignacio Fernández Sarasola, "Voluntad general y representación en el constitucionalismo iusracionalista", Revista de la Facultad de Derecho y Ciencias Politicas, n. ${ }^{\circ} 105$, 2006, pp. 259-268. Para su valor y virtud de trastrueque politico en el iusnaturalismo racionalista, Enrique Álvarez Cora, "Iusnaturalismo racionalista y censura del Santo Oficio", en Enrique Gacto (ed.), Inquisición y censura. El acoso a la inteligencia en España, Dykinson, Madrid, 2006, pp. 270272. Sobre el problema de la tensión entre representación politica y derechos individuales, Jorge Mateus, "Consideraçoes sobre a representaçao: o limiar da soberania e da democracia em Rousseau e Sieyès”, Problemata. Revista Internacional de Filosofía, n. ${ }^{\circ}$ 5-2, 2014, pp. 70-75.

3 En este sentido, Claudia Patricia Fonnegra Osorio, “Benjamin Constant. Libertad, democracia y pluralismo”, Estudios Politicos, n. ${ }^{4}$ 7, 2015, pp. 38-39. 
La sustancia de los derechos individuales reside pues en el quid marcado por su calificativo, y por esta razón la teoría de los derechos individuales vence a cualquier posible desviación o tergiversación antidemocrática de la formación de la voluntad general de la ley. Lo que definió tales derechos, en rigor y puridad, fue su radical individualidad, $\mathrm{y}$ en este sentido el hecho de que permitieran imprescriptiblemente oponer el derecho en y desde el individuo contra toda versión o manifestación, legítima o ilegítima, de poder. El antiguo súbdito se libera del yugo y como ciudadano nunca transmite, para legitimar ningún poder y por mucho que transfiera algún poder (como el legislativo), el poder del campo inviolable de sus derechos. Y no lo hace porque no puede hacerlo, esto es, porque tal derecho (tales derechos) le resulta inherente y connatural. Los derechos individuales son formulados como derechos no solo existenciales, sino ontológicos. Por eso, y amén de la eficacia resultante de su compañía junto a términos filosóficamente evanescentes, como la libertad o la independencia, se antoja tan dificultosa su catalogación, y será siempre característico del iusnaturalismo racionalista su reticencia al numerus clausus $\mathrm{o}$ a su condicionamiento tipificador legal (o constitucional), a pesar de que en esta tipificación, con su fuerza normativa, se adivina también un camino para la eficiencia de su protección. Esto quizá explica el éxito de la igualdad como un derecho presidente entre los derechos, una suerte de primus inter pares, en cuanto principio preñado de abstracción y a la sazón versátil, funcional, al menos potencialmente, en muchos sentidos de la práctica jurídica y de la salvaguardia como núcleo de ese conjunto irrenunciable de derechos.

\section{PRINCIPIO DE IGUALDAD, UNIDAD Y HORIZONTALIDAD DE LOS DERECHOS INDIVIDUALES.}

Los derechos se configuraron individuales en el iusnaturalismo racionalista porque se enfrentaron a los privilegios que, al margen de prescindir de la generalidad (ratio generalis) como característica jurídica, a favor pues de la singularidad (ratio singularis) ${ }^{4}$, nunca se sobrepusieron, sino que antes al contrario obedecieron, a una estructura político y socio-jurídica como fue la de la monarquía absoluta, columna vertebral y pegamento de un orden de estamentos o estados ${ }^{5}$. Es claro que aun el privilegio que beneficiaba a un noble en particular lo premiaba por el hecho de ser noble, esto es, por la razón de su pertenencia a un estado identificado en su singularidad privilegiada otorgada, jerárquicamente, por una alteza fundada en el vicariato divino (recuérdese por ejemplo la renacentista Summa nobilitatis Hispanicae de Juan Arce de Otalora); la diversidad de status, dentro de la nobleza y respecto de otros status, resultaba entonces

4 La posibilidad de que un privilegium sea calificado como generale viene a ser la demostración, sin contradicción ninguna, de que su beneficiario es una generalidad de privilegiados (y así, en las Cortes medievales o modernas, los estados o estamentos cuando reciben, todos ellos, ese determinado privilegio, que no recibe el resto de los súbditos).

5 Para la comprensión de esta pluralidad de status privilegiados, Bartolomé Clavero, Tantas personas como estados. Por una antropología politica de la historia europea, Tecnos, Madrid, 1986, pp. 53-83. 
viable a partir precisamente de la estabilidad de la jerarquía, y conforme a la diversidad de privilegios ${ }^{6}$.

El privilegio es diverso porque es exclusivo. La individualidad de los derechos tiene empero, como rasgo necesario, la unidad, porque responde a la igualdad natural, dado que solo con esta homogeneización igualitaria de la unidad (o dado que solo desde esta homogenización igualitaria de la unidad) pueden predicarse, de todos los individuos y de la misma forma, unos derechos no singularizados. Además, los individuos tienen que ser iguales por definición y por naturaleza si se quiere que la sociedad de la ciudadanía sea una, puesto que solo puede unirse en rigor lo igual, de modo que si la unidad entre los individuos falla, por causa de pertenecer a grupos o status diferenciados en su singularidad privilegiada, la igualdad será inviable en el conjunto mayor, y solo hipotéticamente plausible en el interior de las diferencias o discriminaciones privilegiadas ${ }^{7}$. Los derechos individuales remiten así a un escenario horizontal de unidad, del que sería análogo el principio de división o separación de poderes ${ }^{8}$, mientras que la única posible estabilidad, o si se quiere unidad de la diferencia, cuajada en un escenario de privilegios, ha de ser la ordenación vertical que procura la jerarquía del poder, propia del absolutismo.

Por lo tanto, la unidad de lo igual se sostiene por equilibrio flexible del magma individual coalescente, mientras que la unidad de lo desigual requiere escala rígida de cimientos y grados, tentáculos artificiales y legitimaciones sobrenaturales de dominación. Si los derechos individuales apuntalados por la razón, la igualdad y la libertad son derechos reconocidos como naturales del individuo, conforme a los principios del iusnaturalismo racionalista, y en consecuencia preexistentes y superiores a toda estructura politico-jurídica, su cohesión, y su dinamita potencial de toda jerarquía, reposa todavía mejor remachada.

Si no pudo existir una teoría de la configuración y preservación de derechos colectivos en el iusnaturalismo racionalista - si la teoría de los derechos iusracionalista tuvo que ser indeleblemente de los derechos individuales- se

6 Así queda asentada la estructura política de la monarquía en la Edad Moderna, incorporando aquellas fuerzas privilegiadas al organigrama de gobierno de la república, tras los amagos centrífugos de la pluralidad de status en la Edad Media, propios y condicionados por la construcción de reinos, y que fueron superando, con obstáculos pero por necesidad política de estabilidad, las coronas. Cf. Benjamín González Alonso, "Acotaciones a la historia de la antigua corona de Castilla y a la formación de las actuales Comunidades Autónomas", en Aquilino Iglesia Ferreirós (coord.), Autonomía y soberanía. Una consideración histórica, Marcial Pons, Madrid, 1996, pp. 94-98.

${ }^{7} \mathrm{Y}$ no de forma regular, porque ese ámbito privilegiado no se rige a fin de cuentas por una ratio general.

8 Bien es verdad que bajo la continua tensión práctica política (aunque no faltan ejemplos en la propia teoría histórica constitucional) hacia su jerarquización en un sentido u otro; la jerarquización de las estructuras de poder emanadas de la soberanía una e igual de los ciudadanos, en retorcimiento contra la horizontalidad de su legitimación, es el escollo constante en la construcción contemporánea de un Estado fundado en los derechos individuales, lo que se manifiesta en la yuxtaposición de los deberes a los derechos: con esta perspectiva, Julián Sauquillo, "La Declaración de los Derechos del Hombre y del Ciudadano y el liberalismo revolucionario (a vueltas con los origenes)", Cuadernos Electrónicos de Filosofía del Derecho, n. ${ }^{\circ}$ 15, 2007, pp. 9-10. No ha de confundirse, por otra parte, la especialidad de la división de poderes (compatible con una ratio generalis) con la ratio singularis de la jurisdicción privilegiada. 
debe a que esos supuestos derechos colectivos habrian sido susceptibles perfectamente a su absorción por las estructuras (estamentales, gremiales, etc.) de privilegios, en su coincidencia acotada en colectivos, del absolutismo, careciendo por lo tanto de toda fuerza deconstructora. Hay que tener en cuenta que el pluralismo corporativo fue un instrumento flexibilizador de la jerarquía absolutista, para que no crujiera y estallase, por falta de dilatación, la propia espina dorsal del poder (de ahí la querencia del poder absoluto por las metáforas corporativas y hortelanas). Solo la unidad igual atómica propuesta por los racionalistas estaba en condiciones de demoler el orden jerárquico vertical del iusnaturalismo teológico (no hay que olvidar su campo intelectual de experimentación en el diseño de una clave cristiana de minuspapismo conciliarista $^{9}$ ), dañando al mismo tiempo (prueba de la irrelevancia de supuestas alternativas o matices) tanto su planteamiento estrictamente corporativo (asunción de poder sin límites por el cerebro monárquico) cuanto su planteamiento pactista (limites del cerebro monárquico para un asunción absoluta de poder), puesto que en definitiva ambos planteamientos, en el fondo coincidentes (incluso en sus discursos ideológicos y no estrictamente jurídicos, según el vaivén de las situaciones históricas), ordenaban jerárquicamente cuerpos privilegiados. $\mathrm{Y}$ así no es casualidad que, cuando contra el constitucionalismo liberal igualitario se defiendan los derechos históricos de los organismos naturales, la retrohistoria-ficción imagine con suavidad, a la manera historicista, la congruencia de su encaje con aquellas metáforas medievales evocadoras, al fin y al cabo, de la armonía pautada de la diferencia privilegiada.

\section{DESNATURALIZACIÓN Y LEGALIZACIÓN DE LOS DERECHOS INDIVIDUALES CONSTITUCIONALES.}

El espinoso problema de la positivación de los derechos individuales naturales e imprescriptibles no significó desidia práctica de su filosofia, porque los diecisiete artículos de la Déclaration des droits de l'homme et du citoyen de 1789 cumplieron bien pronto esa misión. Tras la presidencia de la libertad y la igualdad (la distinción social solo ha de caber por razón de utilidad común) el artículo $2 .^{\circ}$ de la Déclaration rezaba que "Ces droits sont la liberté, la propriété, la sûreté et la résistance à l'oppression". En este mismo precepto, y en el resto del articulado, se expresaban además la libertad de asociación política, la soberanía nacional, el principio de legalidad, la representación política, la presunción de inocencia, la libertad de opinión, la garantía de una fuerza pública, la necesidad de una contribución pública, el control de la administración pública, la separación de poderes y la inviolabilidad de la propiedad (salvo necesidad pública y con indemnización) ${ }^{10}$. Se trataba, pues, de un cumplido catálogo, preocupado sobre todo por definir la posición de los derechos de los ciudadanos respecto de la estructura politica y su funcionamiento. Con todo, la Déclaration consiste en una positivación que, en el artículo 4, encarga exclusivamente a la ley, como expresión de la voluntad general (artículo 6), la fijación de los límites de tales derechos, en orden a su garantía respecto de toda la ciudadanía. De esta manera, la unidad de la igualdad de derechos se preserva al garantizar, mediante la ley,

9 Enrique Álvarez Cora, “Derecho canónico y censura del Santo Oficio”, en Enrique Gacto (ed.), Inquisición y censura. El acoso a la inteligencia en España, Dykinson, Madrid, 2006, pp. 213-232.

10 Décret de l'Assemblée Nationale du 3 Septembre 1791. 
que la fuerza de los derechos no provocará internamente un desequilibrio o una ruptura (la hipótesis desvertebradora de la unidad igual consistente en que el derecho de un sujeto ruja contra el derecho de otro): la ley, o la constitución, es contemplada, pues, de una forma optimista, sin atender a su derivación en límite de derechos o entendiendo que este límite será, en realidad, el eje de la garantía de su unidad, de su vertebración general.

Tales derechos individuales (del hombre, del ciudadano) son los que se encuentran barajados en la experiencia constitucional decimonónica española. Pero conviene recordar que en las constituciones se evitó, por regla general, la calificación de los derechos individuales como naturales e imprescriptibles, y esto significaba un apuntalamiento del principio de legalidad, en el sentido presupuesto de un principio de constitucionalidad o constitucionalización, que excluye una naturaleza de los derechos individuales naturales con fuerza expansiva supralegal y aun el argumento de que el principio de legalidad se limita a asegurar la coexistencia de dichos derechos naturales con fuerza expansiva, porque reduce estos derechos individuales a su expresión constitucional o legal. Eso no quiere decir, sin embargo, que la concepción supralegal más radical de los derechos individuales, propia de la filosofia jurídica del iusnaturalismo racionalista, no siguiera presente en el pensamiento político. De hecho, así lo demuestran la Constitución de 1869, cuando afirma que no quedan prohibidos los derechos no consignados en el propio texto constitucional (artículo 29), y el proyecto constitucional de 1873, todavía con un iusracionalismo más palmario, al considerar los derechos como "naturales" y "anteriores y superiores a toda legislación positiva" (título preliminar) ${ }^{11}$.

Lo que predominó, sin embargo, fue la constitucionalización y legalización de los derechos. Y también debe decirse que esta legalización solo excepcionalmente fue interpretada como un factor de protección de los derechos individuales. Sucedió así en la Constitución de 1812 (artículo 4. ${ }^{\circ}$ : "La nación está obligada a conservar y proteger por leyes sabias y justas la libertad civil, la propiedad, y los demás derechos legítimos de todos los individuos que la componen") ${ }^{12}$, y una vez más tanto en la Constitución demócrata de 1869 como en el proyecto constitucional republicano de 1873 (con repugnancia, en el artículo 22 y en el título preliminar respectivamente, a las disposiciones preventivas establecidas por ley o autoridad respecto del ejercicio de los derechos) ${ }^{13}$. Contra estas excepciones, se impuso antes bien una concepción de la legalización a la manera de "sujeción" de los derechos ${ }^{14}$, durante el tiempo sumado de mayor vigencia de las constituciones respectivamente transaccionista, moderada y conservadora de

11 Constitucion democratica de la nacion española, promulgada el dia 6 de junio de 1869 , Imprenta de "E1 Imparcial", Madrid, 1869.

12 Constitucion politica de la Monarquia española. Promulgada en Cadiz á 19. de Marzo de 1812, Ymprenta Real, Cádiz, 1812.

13 Proyecto de Constitucion federal de la República española, en Archivo de las Cortes Españolas, leg. 177, n. 239.

14 Lo que coincide con otra mutación: mientras el derecho individual natural puro (iusnaturalista racional) beneficiaba a un individuo que, en su propia denominación, ni siquiera parecía un sujeto jurídico (sino un buen salvaje), el individuo a quien la Constitución reconoce unos derechos es ya un individuo constitucionalizado evidentemente como ciudadano (un buen padre de familia). Cf. por ajustado Francisco Bobadilla Rodríguez, "Del buen salvaje al ciudadano moderno y vuelta", Mercvrio Pervano, n. ${ }^{\circ}$ 525-526, 2012-2013, pp. 203-206, 209-212. 
1837 (artículo $\left.2 .^{\circ}\right)^{15}, 1845$ (artículos $2 .^{\circ}$ y $\left.3 .^{\circ}\right)^{16} \mathrm{y}$, sobre todo, 1876, en la que parece apuntarse la idea de la legalidad como factor de equilibrio de derechos (artículo 14, párrafo primero: "Las leyes dictarán las reglas oportunas para asegurar a los españoles en el respeto reciproco de los derechos que este título les reconoce...") para terminar en un canto a tumba abierta permisivo de su restricción (“... sin menoscabo de los derechos de la nación, ni de los atributos esenciales del poder público") ${ }^{17}$.

\section{DESINDIVIDUALIZACIÓN Y DERECHOS COLECTIVOS SOCIALES.}

La sujeción a ley de los derechos individuales tuvo un efecto más allá de la yugulación de su expansión natural frente al poder político, cual fue el virus de su desindividualización, que verdaderamente podía ya intuirse en la exclusión constitucional mayoritaria de su carácter natural. Lo que hace la ley que regula el derecho individual es establecer un campo de ejercicio cuyas fronteras están determinadas por el interés de clase. A diferencia del estamento, la clase social no utiliza el instrumento del privilegio y su razón singular frente a la ley general ${ }^{18}$, sino la ley general y su eventual criterio de especialización, respetando formalmente con su abstracción el principio de igualdad, mas con el predominio en cualquier caso de una determinada inclinación material; al hacerlo (así puede contemplarse nítidamente en la legislación decimonónica electoral o sobre delitos de imprenta) se refleja y se sirve a un interés concreto, provocando irremediablemente una particularización. Entonces, esta particularización, al postularse como general (verbigracia, al operar no a favor de determinados sujetos, sino de todos los que cumplan con una condición, como el nivel de renta) con el objeto de no contravenir la igualdad jurídica, plasma un grupo afectado por el interés, y en consecuencia desindividualiza el derecho, porque genera un derecho colectivo. Esta generación del derecho colectivo agrede, inevitablemente, a los derechos de los individuos que no forman parte de la generalidad acotada, con mayor violencia si el sistema jurídico relaja la protección del derecho individual, y tan solo promueve una legislación de sujeción o limitadora (o sea,

15 Constitucion de la Monarquia española, promulgada en Madrid a 18 de junio de 1837, impresa de orden de S. M. la Reina Gobernadora, Imprenta Nacional, Madrid, 1837.

16 Constitucion de la Monarquia española, Imprenta Nacional, Madrid, 1845.

17 Constitucion de la Monarquía española, Imprenta Provincial, Albacete, 1876.

18 Estamento y clase son formas históricas de "estratificación social"; "Como noción antitética del concepto de clase, en que la solidaridad entre sus miembros deriva de una 'conciencia de clase' y de su integración en sindicatos y partidos, el estamento se constituye en una verdadera 'comunidad'. De ahí que la clase implique una división 'asistemática y accidental' de la sociedad, mientras que al estamento se le considera como un tipo de conglomerado social sistemático y orgánico, respecto del 'estructurado' sistema social, en su conjunto. [...] En la clase el criterio determinante es, fundamentalmente, de tipo económico [...] Los estamentos comportan una clara diversificación jurídica (privilegios) acorde con una división funcional, mientras que las clases, diferenciadas económicamente..., se mueven en el terreno de una igualdad jurídica que rechaza los privilegios": Juan Ferrando Badia, "Casta, estamento y clase social", en Revista de Estudios Políticos, n. ${ }^{\circ}$ 198, 1974, pp. 28-30. 
una habilitación parcial del derecho, contra su prohibición, que implica la prohibición para quien no resulta su beneficiario ${ }^{19}$ ).

El vínculo, en el constitucionalismo decimonónico, del liberalismo moderado y conservador con una comprensión elitista, en clave de clase burguesa, de los derechos ya solo opacamente individuales, explica la reacción constitucional demócrata y del proyecto constitucional republicano, que pretendió contraponer la argumentación del iusnaturalismo racionalista con su ideario de preexistencia y resistencia a la legalización de los derechos individuales (naturales). Pero hay que advertir que esta respuesta, solo vigente en la Constitución de 1869, descubrió entonces, tanto como la pervivencia de una cierta pureza del iusnaturalismo racionalista, la debilidad actual de su hundimiento tras la ola moderantista de la sujeción legal de derechos, y también una timidez axiológica (así, por ejemplo, cuando brindó la legislación penal común como cauce, en vez de los delitos especiales, para la regulación de los límites de la libertad de expresión, sin alcanzar a ahondar en el problema de fondo de su extensión contrapoder ${ }^{20}$ ) debida a la inestabilidad politica y a las contradictorias reservas represivas que aquella alimentaba en el propio sistema político-jurídico. Quizá por ello, y como una ruta más en boga, la Constitución demócrata, con su reconocimiento de los derechos de reunión y asociacion, así como la legislación del sexenio, mostró sensibilidad hacia las ideologías que habian de propugnar la defensa de los derechos sociales, y en este sentido abrió una puerta a la ampliación y extensión de los derechos individuales al mismo tiempo que pretendía superar la concepción burguesa de los derechos colectivos.

En efecto, por estos mismos años finales de los 60 comienza la historia de las asociaciones de la Internacional en España. Dejando al margen la ideología anarquista (en cierta medida conectable con la vocación anarcoide y materialista caracterizadora de un sector del original iusnaturalismo racionalista) ${ }^{21}$, el

19 Es claro en el sufragio restringido, capacitario y censitario. Y cabe la combinatoria, como en la Constitución de 1812, con un sufragio activo universal indirecto (artículo 34) y un sufragio pasivo censitario (artículo 92).

20 Enrique Álvarez Cora, "Patología de la libertad de imprenta en el liberalismo español", Anuario de Derecho Penal y Ciencias Penales, n. ${ }^{\circ}$ 70, 2017, pp. 85-112.

21 María Pilar Salomón Chéliz, "Internacionalismo y nación en el anarquismo español anterior a 1914", en Ismael Saz y Ferrán Archilés (eds.), Estudios sobre nacionalismo y nación en la España contemporánea, Prensas Universitarias de Zaragoza, Zaragoza, 2011, pp. 141, 148, 167-168, explica el pensamiento anarquista, para el cual la identidad territorial no es relevante y el nacionalismo merece rechazo como "religión del Estado moderno" y "trampa burguesa", y añade: "El antipoliticismo, antiestatismo e internacionalismo de los anarquistas no eran incompatibles con el sentimiento de afecto hacia la tierra y la comunidad en la que habían nacido o vivian. Ese era el sentido positivo que atribuían al término 'patria' y, desde luego, no lo rechazaron en absoluto. La tendencia cosmopolita había de progresar y, finalmente, el mundo devendria la única patria; en ese momento, la fraternidad universal sustituiría a la concepción burguesa de patriotismo. A pesar de tales aspiraciones internacionalistas, el sentido positivo otorgado al concepto de patria actuaba como una fisura a través de la cual podian colarse los sentimientos patrióticos y la identidad nacional. Evidentemente, los anarquistas no se identificaban con los intereses estatales, sino con el destino de los trabajadores. [...] Al subrayar tales ideas, los anarquistas españoles contribuyeron simultáneamente a reproducir cierta noción de identidad nacional española y a remodelarla, aunque este no fuera su objetivo. Tanto el discurso difundido por la prensa y las publicaciones ácratas como la acción desarrollada por los medios libertarios se definieron en un marco nacional español, no exento de referencias universitalistas, como había sido típico del primer discurso de nación nacido con la Revolución francesa". 
socialismo marxista procederá a una comprensión de los instrumentos para responder al constitucionalismo burgués que profundiza con energía no tanto en el individualismo o el liberalismo de las propuestas demócrata o del primer republicanismo, cuanto en su receptividad con amplitud ciudadana respecto de los derechos colectivos. Habida cuenta de que la constitucionalización y la legalización de los derechos había impulsado una transformación no solo desnaturalizadora, sino aun desindividualizadora de los derechos, y por lo tanto asentada su asimilación en cuanto derechos declarados y regulados, objeto de titularidad de una particularidad social oligárquica, la clase de la burguesía, la interpretación marxista optará, en vez de por una crítica de la adulteración de los derechos individuales, antes bien por disputar ese mismo escenario constitucional y legalizado, y definir su propia clase protagónica, el proletariado, con el fin de poner en funcionamiento, como forma de superación de la particularización desigualitaria ${ }^{22}$, la lucha de clases $^{23}$.

Ahora bien, aunque se trate de una reacción, y por mucho que en ella se produzca un desarraigo respecto de las bases filosóficas de los idearios de la izquierda política (democratismo, republicanismo, socialismo utópico), el socialismo marxista va a conseguir otorgar densidad a la categoría de los derechos que enarbola a partir de su pertenencia a las reivindicaciones de su propia clase proletaria. Y no deja de ser lógico que estos derechos colectivos de clase proletaria, identificados como derechos sociales, se arroguen entonces el campo de los derechos en vanguardia, porque, desindividualizados los derechos constitucionales, legales en vez de naturales, y restringidos al legalizarse, bocabierta de un pez muerto que resbala en las manos de la burguesía, fracasadas las reacciones demócrata y republicana, la única carne viva parece latir en estos nuevos colectivos y luchadores derechos sociales proletarios, de los campesinos y los obreros. Así, significativamente, el derecho natural individual de asociación, una vez legalizado, $\operatorname{limitado}^{24}$ y desindividualizado, renace no solo

22 El principio de igualdad, pilar del iusnaturalismo racionalista, mantiene su función basilar en el socialismo, ahora no como imán de racionalidades libres, sino, como en el artículo 25 de la Constitución de 1931, en calidad de eliminación de privilegios (particularismos so capa de igualdad jurídica) burgueses u oligárquicos, por los ámbitos de lo social, lo político, lo económico, lo religioso, lo familiar o lo sexual: "No podrán ser fundamento de privilego jurídico: la naturaleza, la filiación, el sexo, la clase social, la riqueza, las ideas politicas ni las creencias religiosas. / E1 Estado no reconoce distinciones y títulos nobiliarios". Bien podría decirse que el principio de igualdad es el derecho que mejor acoge simultáneamente su preservación individual y su transfiguración en derecho colectivo, y por lo tanto el derecho que mejor preserva una identidad politica de izquierda, a partir del racionalismo, que permite la supervivencia de una comunión entre lo individual y lo social.

23 Ferrando Badía, "Casta, estamento y clase social", op. cit., p. 59: "La teoría marxista de la lucha de clases interpreta el antagonismo politico como un fenómeno determinado por la existencia de clases en oposición; clases que se determinan por las particulares circunstancias del sistema de producción y de régimen de propiedad. Esta dependencia de los fenómenos políticos y sistemas de producción supone, por tanto, la dependencia del antagonismo politico respecto de la lucha de las clases sociales respecto del régimen de propiedad, del régimen de propiedad respecto del sistema de producción, de los sistemas de producción respecto de las técnicas o fuerzas productivas. Los regimenes políticos son superestructuras dependientes del sistema de producción".

24 Puede comprobarse en José Daniel Pelayo Olmedo, "El derecho de asociación en la historia constitucional española, con particular referencia a las leyes de 1887 y 1964", Historia Constitucional, 8, 2007, pp. 2-18. 
como un derecho colectivo, sino también como un instrumento de la reivindicación de nuevos derechos sociales. Será en el seno de los derechos sociales colectivos donde podrá asistirse a lo que en principio se aventuró como propio de derechos individuales: la eclosión de un derecho aún no constitucionalizado ni legalizado, como el derecho de huelga ${ }^{25}$.

Se acertará si se supone con cierto fatalismo que comenzará en seguida el proceso de constitucionalización y legalización de los derechos colectivos sociales, con muy alternativos espíritus. Y de nuevo la legalización podrá ser el camino de la protección o de la represión; de cualquiera de las formas, se trata al fin y al cabo de la vía ensayada antes para el reconocimiento, la absorción y la mutilación de los derechos individuales. Por una parte, el impulso de cobertura constitucional, novedoso para el mundo obrero, está ya presente en un texto vinculado al constitucionalismo conservador canovista (pero con trazas de un organicismo político muy distante del liberalismo) cual es el anteproyecto constitucional de $1929^{26}$, en tiempos de la dictadura de Primo de Rivera ${ }^{27}$, cuya legislación laboral por lo demás, como es sabido, resulta, en calidad y número,

$25 \mathrm{El}$ reconocimiento del derecho puede ir precedido (y aun sucedido, como en los delitos de imprenta) por la necesidad de dirimir si el acto tiene o no un carácter delictivo; así sucede con la huelga en la circular de la Fiscalía del Tribunal Supremo de 20 de junio de 1902, en Gaceta de Madrid, n. ${ }^{\circ}$ 173, 22 de junio de 1902, p. 1238: "Viniendo ahora á lo que es materia propia de nuestra competencia, afirmo resueltamente, y con la más arraigada convicción, que no es delito definido ni castigado en el Código penal la coligación y la huelga con el fin de obtener ventajas en las condiciones del trabajo y en la cuantía de la remuneración, y aun cuando no han de sorprender á V. S. las razones que tengo para llegar á tal conclusión, habré de exponerlas someramente, porque de una parte lo exige la actualidad del problema y de otra lo aconseja el respeto debido á la opinion ajena, puesto que no faltan jurisconsultos de reconocida autoridad que dan por supuesto que las huelgas y coligaciones á que me refiero, revisten siempre el carácter de delito, con arreglo al precepto del art. 556 del Código antes citado, que dice así: 'Los que se coligaren con el fin de encarecer ó abaratar abusivamente el precio del trabajo ó regular sus condiciones, serán castigados... etc.' Esto sentado, ¿puede sostenerse en buena, rigurosa y natural interpretación, que la simple huelga, la mera coalición de operarios, con los fines dichos, constituye delito? Tan no es así, que yo estimo, y no juzgo ir descaminado, que el texto, cuyo primer inciso acabo de copiar, es una confirmación explícita y concluyente de que, para el legislador, el uso de tales medios de resistencia y defensa, es legítimo, y sólo deja de serlo, cuando á su sombra, se cometen abusos. El adverbio abusivamente que el precepto aludido contiene, condiciona la transgresión de que trato, á la manera que la malicia, la negligencia ó la ignorancia inexcusable condicionan los delitos de prevaricación; la violencia condiciona la coacción, y la habitualidad y el abuso de autoridad ó confianza condicionan el delito de corrupción de menores, hasta el punto que sin esos elementos no hay delincuencia en los órdenes respectivos, como tampoco la habrá en las coligaciones y en la abstención del trabajo por los operarios, si falta el abuso. En la ley no cabe el empleo de palabras inútiles. Cada una tiene su significado y oficio. Si la voluntad del legislador hubiera sido castigar como delito el acto de coligación, sobraba el abusivamente; y como las leyes se han de suponer redactadas con absoluta precisión de lenguaje, porque de lo contrario ocasionarian honda perturbación, lo que castiga el art. 556 del Código no es la coligación y la huelga, sino el abuso que las hace degenerar en coacción incompatible con la libertad á que todos tienen derecho".

26 Particularmene en el artículo 28, sobre la libertad de contratación y de trabajo, del título III sobre "los deberes y derechos de los españoles y de la protección otorgada a su vida individual y colectiva".

27 "Asamblea Nacional. Anteproyecto de Constitución de la Monarquía española, redactado por la sección 1. a , 'Leyes Constituyentes", en Diario de Sesiones del Congreso de los Diputados, legislatura 1927-1929, 6 de julio de 1929 , apéndice $1 .^{\circ}$ al n. ${ }^{\circ} 48$, pp. 1-16. 
muy relevante ${ }^{28}$. Por otra parte, y con una orientación muy diferente, en sintonía con el socialismo marxista, la Constitución de 1931 unirá, en su título III sobre los "Derechos y deberes de los españoles", las "Garantías individuales y políticas" (individuales, sí, pero no derechos, acaso por el aroma burgués de la palabra) y los artículos sobre "Familia, economía y cultura" en los que, tras combinar propiedad privada, socialización, nacionalización e intervención estatal (artículo 44), se define, con un punto de vista de clase, el trabajo como obligación social protegida mediante la legislación social (artículo 46) y se declara la protección del campesino y el pescador (artículo 47).

\section{DESINDIVIDUALIZACIÓN Y DERECHOS COLECTIVOS NACIONALES.}

La tensión entre los derechos desinvidualizados (colectivos) de clase oligárquica burguesa y los derechos colectivos de clase proletaria confirma un desplazamiento global del pensamiento sociopolítico y jurídico hacia una concepción colectiva (no iusnaturalista racionalista) de los derechos. En esta tesitura, hay que añadir a la pujanza del avance de los derechos sociales del proletariado una paralela precipitación de los denominados derechos nacionales, que se derivan de dos corrientes ideológicas contrapuestas, a saber, los idearios regionales que postularon el reconocimiento de nuevos sujetos colectivos de pretendida nacionalidad, y la reacción por parte del liberalismo conservador no limitada a la preservación de sus derechos de clase burguesa sino dispuesta a la formulación de derechos nacionales de raigambre estatal.

La ebullición romántica de los sentimientos regionales nacionales se situó históricamente en paralelo a la emergencia de los derechos sociales, a raíz de la apertura política que significó el sexenio democrático, cuya lábil práctica implicó en todo caso una palmaria reacción contra la concepción sujeta a la ley de los derechos propia del constitucionalismo liberal moderado ${ }^{29}$. Contradictoriamente, la reticencia hacia la ley permitía no solo la defensa mayor de los derechos individuales, sino también la formulación de otros derechos colectivos ${ }^{30}$. Fue el

28 Para una valoración global de la legislación social liberal, Antonio Martín Valverde, Fernando Valdés Dal-Ré, Manuel C. Palomeque López, María Emilia Casas Baamonde, Fernando Pérez Espinosa y Joaquín García Murcia, La legislación social en la Historia de España. De la revolución liberal a 1936, Congreso de los Diputados, Madrid, 1987. La sistemática de la recopilación legislativa resulta indicativa de los períodos sobresalientes: "I. De la revolución liberal a la Restauración", "II. Restauración monárquica”, "III. Dictadura de Primo de Rivera” y "IV. Segunda República”.

29 Pere Anguera, "El nacionalismo catalán desde sus origenes a 1930", en Jean-Louis Guereña y Manuel Morales Muñoz (eds.), Los nacionalismos en la España contemporánea. Ideologías, movimientos y simbolos, Centro de Ediciones de la Diputación de Málaga, Málaga, 2001, pp. 95-101, se ocupa de esta eclosión en tiempo demócrata de las "ideologías subyacentes" durante el liberalismo moderado en relación con el nacionalismo catalán.

30 Sobre la naturaleza de derechos colectivos de los derechos históricos, Eduardo Nieto Arizmendiarrieta, "Reflexiones sobre el concepto de derechos históricos", Revista Vasca de Administración Pública, n. ${ }^{\circ}$ 54, 1999, pp. 159-167; en p. 160: "Evidentemente, teniendo en cuenta que los derechos colectivos sólo pueden ser entendidos de forma instrumental, esto es, como un refuerzo de los derechos individuales, sería injusto primar los primeros sobre los segundos. En tal sentido, desde una concepción liberal, los derechos colectivos sólo pueden reputarse legítimos cuando traten de proteger al grupo del impacto de decisiones externas. Es decir, cuando un grupo o comunidad intente proteger su existencia e identidad específica limitando las decisiones de la sociedad en la que está englobado". 
proyecto constitucional de 1873, en la I República, el primer intento de asimilar, con la propuesta de una estructura de carácter federal, la protección garantista de los derechos individuales y aquellas reclamaciones colectivas regionales, con el embrujo de su estatalización nominal pero siempre, de acuerdo con su profundo iusnaturalismo racionalista, sin dañar un ápice del sobrevalor de los derechos individuales. Así lo demuestra en el proyecto constitucional el trazo de una suerte de poder individual en el seno de los poderes del Estado (artículo 40), la atribución de la soberanía a todos los ciudadanos (artículo 42) y el límite marcado a los organismos por "los derechos de la personalidad humana" (artículo 43), paralelo a una ordenación jerárquica de los derechos de los organismos (municipios, Estados y Federación) ${ }^{31}$. Pero este fue un ensayo político constitucionalmente proyectado que ni siquiera alcanzó la vigencia.

En la Constitución canovista de 1876 se incluyó una suerte de cláusula interpretativa de los derechos que parecia alternativa y resultaba contraria a aquella otra, ya citada, de la Constitución de 1869 (artículo 29) en la que se reconocía su existencia al margen del propio texto constitucional. En la nueva cláusula conservadora (en el párrafo primero del artículo 14, también citado anteriormente), quedaba previsto el dictado por la ley de las "reglas oportunas para asegurar a los españoles en el respeto reciproco de los derechos" constitucionalmente reconocidos, pero además esta legalización resultaba sometida a un límite amplio y políticamente versátil, pues la regulación legal tendría que producirse "sin menoscabo de los derechos de la nación, ni de los atributos esenciales del poder público". Así reposan innovadoramente formulados unos "derechos de la nación", paralelos a los "atributos del poder público", de los que bien puede afirmarse que son derechos colectivos, del máximo diámetro en la medida de su atribución a la nación, titular (o cotitular, unido el rey) de la soberanía.

Los derechos de la nación funcionaban en la Constitución como una frontera de los derechos individuales, constitucionalizados y legalizados con carácter general en la cláusula interpretativa mencionada. Su inclusión daba lugar asimismo a una carambola política: el mantenimiento formal, en un texto propicio por naturaleza al rumbo burgués de los derechos desindividualizados, de los derechos individuales acogidos con amplitud en la Constitución de 1869, último baluarte de una cierta dosis de iusnaturalismo racionalista. La maniobra consistía en mostrar generosidad en la catalogación de los derechos, manteniendo el alcance de la Constitución más fértil en derechos individuales, habida cuenta que los condicionamientos legales de estos habian sido convenientemente amartillados con la sumisión a la nueva categoría de los derechos de la nación, en conexión añadida, y expresa, con los "atributos" politicos del Estado ${ }^{32}$. No es casualidad que la cláusula interpretativa de los

31 Proyecto de Constitución de 1873. Artículo 40: "En la organización politica de la Nación española todo lo individual es de la pura competencia del individuo; todo lo municipal es del Municipio; todo lo regional es del Estado, y todo lo nacional de la Federacion". Artículo 42: "La soberania reside en todos los ciudadanos y se ejerce en representacion suya por los organismos políticos de la República constituida por medio del sufragio universal". Artículo 43: "Estos organismos son: / El Municipio. / El Estado regional. / El Estado federal ó Nacion. / La soberanía de cada organismo reconoce por limite los derechos de la personalidad humana. Además, el Municipio reconoce los derechos del Estado, y el Estado los derechos de la Federacion".

32 Carlos Dardé, "Nación y Estado en el Partido Conservador", en Antonio Morales Moya, Juan Pablo Fusi Aizpurúa y Andrés de Blas Guerrero (dirs.), Historia de la nación y del 
derechos de la Constitución de 1876 fuera integrada en el anteproyecto constitucional primorriverista de 1929 (párrafo primero del artículo 30).

El repliegue del liberalismo conservador hacia la configuración de unos derechos nacionales o de la nación o del Estado (como vestidura jurídica de la nación) que no son estrictamente los de la ciudadanía española, sino precisamente el límite de los derechos de los ciudadanos, se realizó con el instrumento legitimador de una ideologia historicista, latente en tantos aspectos del texto constitucional canovista (soberanía compartida entre el rey y las Cortes, sufragio restringido, confesionalidad católica, bicameralismo, derecho regio de veto legislativo...). El historicismo, asi pues, marcaba el rumbo de los derechos regionales y también de los derechos estatales. Pero los derechos nacionales del Estado constituían en último término una reacción, en su misma clave colectiva, tanto frente a los derechos sociales (de ideología marxista) cuanto frente a los derechos nacionales (de ideología regionalista o nacionalista). Pues bien, así como las constituciones tendieron a asumir la problemática de los derechos sociales, confiando en la doma de la legalización, el constitucionalismo moderado en cierta medida $^{33}$ y sobre todo la práctica politica del liberalismo conservador mostraron clara proclividad a la transacción con ese conglomerado ideológico de derechos nacionales regionales que habria de manifestarse, con diferentes rasgos, en el carlismo (de manera especialmente beligerante), el foralismo y el nacionalismo ${ }^{34}$.

nacionalismo español, Galaxia Gutenberg, Madrid, 2013, pp. 494-499, resaltando la importancia de la idea de nación para Cánovas, dice: "La idea de Cánovas del Estado también es ecléctica, ya que si por una parte se proclama 'fundamentalmente individualista' [...] por otra defiende que se otorguen 'al Estado grandes atribuciones en la vida humana, no solo como institución de derecho y garantía de derechos, sino como instrumento natural y necesario de progreso y de perfección para los hombres'. El problema consistía en alcanzar un equilibrio entre los derechos individuales y la autoridad del Estado, para hacer compatible la libertad y el orden: 'es el establecimiento de los derechos individuales inseparable de la manera en que se organice y constituya el Estado, porque este ha de representar precisamente el derecho absoluto de cada uno delante del derecho absoluto de cada otro [...] Dadme para cada derecho individual, por medio del Estado, la libertad y la seguridad que él en sí necesita, y yo os doy [...] en toda la extensión que queráis, cualquier derecho individual"'.

33 Constitución de 1845: "Que siendo nuestra voluntad y la de las Córtes del Reino regularizar y poner en consonancia con las necesidades actuales del Estado los antiguos fueros y libertades de estos Reinos [...]”.

34 Bartolomé Clavero, Fueros vascos. Historia en tiempo de Constitución, Editorial Ariel, Barcelona, 1985, pp. 75-92, diferencia carlismo de foralismo: el primero se caracteriza por un anticonstitucionalismo nuclear y un predominio eclesiasticista, con una monarquía "supervisora" de la legislación tradicional y contra toda "autodeterminación social", mientras, con un mismo referente católico, el foralismo, susceptible de transacción con el constitucionalismo, se centra en la defensa de sus instituciones históricas locales administrativas más sus "leyes especiales" (una especie de "autonomía negativa"), y el nacionalismo, tomando elementos de ambos, oscila hacia la propulsión del separatismo o independentismo. La secesión, para Jon Arrieta, “Las 'imágenes' de los Derechos históricos: un estado de la cuestión”, en Miguel Herrero de Miñón y Ernest Lluch (eds.), Derechos históricos y constitucionalismo útil, Crítica, Barcelona, 2001, pp. 241-242, es "el punto de inflexión" que separa el fuerismo del nacionalismo. Si los derechos nacionales del conservadurismo liberal representan o señalan hacia el nacionalismo español (exacerbado y mutado en el totalitarismo franquista), su transaccionismo con el nacionalismo (en una especie de comunión en lo artificioso) se explica en parte, según Jon Juaristi, Vestigios de Babel. Para una arqueología de los nacionalismos españoles, Siglo Veintiuno, Madrid, 1992, p. 101, de esta manera: "Contra lo que suele afirmarse, el nacionalismo español (tanto el liberal como el conservador) ha mantenido hacia la comunidad vasca una actitud, si no del todo deferente, al menos respetuosa. Porque el sostenimiento del mito esencialista de España exige que los vascos formen parte 
Por último, la máxima expresión de los derechos nacionales estatales del conservadurismo liberal tendrá lugar, con otra máscara, tras la experiencia del segundo republicanismo y el trauma de la Guerra Civil. Estrictamente contra los derechos de la nación liberal, contra el transaccionismo burgués respecto de los derechos nacionales regionales y contra los derechos sociales de clase trabajadora abanderados por la II República, el totalitarismo del Nuevo Estado franquista arrasará el escenario de los derechos, desde una crítica radical y conjunta al liberalismo político y al marxismo. Así las cosas, los derechos individuales quedarán no desplazados o transfigurados, sino desalojados y extirpados de su posición axial en la estructura y teleología del Estado, de modo que cuando algunos sean recuperados, formalmente, en el Fuero de los Españoles de 1945, se concebirán como una especie de excrecencia, con el título de "derechos de la personalidad humana", obediente a la resurrección de la referencia fundamental de la doctrina de la justicia social católica, y siempre extremando los mecanismos de legalización y sus limites 35 ("unidad espiritual, nacional y social de España”, en el artículo 33) ${ }^{36}$.

En cuanto a los derechos sociales, fueron objeto de asimilación a través del programa ideológico del falangismo, y estructurados orgánicamente en el Nuevo Estado mediante el dibujo del verticalismo colectivista nacional-sindicalista y católico ${ }^{37}$. Los preservará el Fuero del Trabajo de 193838; y aunque la deriva tardofranquista procapitalista supondrá sin duda un cambio de tercio, no precisará de una alteración de los presupuestos ideológicos, suministrados de nuevo, ante la necesidad de actualización, por la doctrina económica católica, en sus lecturas protoliberal y pragmática. Los derechos nacionales regionales serán ignorados; una vez decantados en su foralidad (curiosamente coincidente con la retrógrada denominación pseudoconstitucional de "fuero") y en el ámbito jurídicoprivado de su materialidad, las compilaciones forales responderán a la persistente rémora historicista manifestada en la conservación de los anteriores apéndices forales (conforme a la ley de bases del Código civil) pero de acuerdo con

inalienable de la Nación, pero también, paradójicamente, que constituyan una comunidad diferenciada, perspicua, reconocible de inmediato por unos rasgos culturales, lingüisticos e incluso 'raciales' no compartidos por el resto de los españoles. De hecho, el nacionalismo español encomendó tácitamente a los vascos la función de representar a la España arcaica y eterna. A los ojos del nacionalista español, el pueblo vasco aparece aún como el único pecio que aflora a la superficie histórica de aquella España prehistórica que naufragó en la noche de los tiempos". En un sentido similar que amplía el diagnóstico hacia el resto de "pecios", la idea de una España histórica de conquista propia del nacionalismo español remite, en general, a una agregación en marcha incompatible con la unidad real original (aunque no con la mítica o antigua).

35 Enrique Álvarez Cora, La Constitución postiza. El nacimiento del Fuero de los Españoles, Biblioteca Nueva, Madrid, 2010, pp. 37-68, 335-368.

36 "Fuero de los Españoles", Boletin Oficial del Estado (= BOE), n. ${ }^{\circ}$ 199, 18 de julio de 1945, pp. 358-360.

37 Para la comprensión de los derechos sociales en el Nuevo Estado, a partir del concepto deber/derecho de trabajo, Josefa Dolores Ruiz Resa, Los derechos de los trabajadores en el franquismo, Dykinson, Madrid, 2015, pp. 209-523.

38 "Fuero del Trabajo", BOE, n. ${ }^{\circ}$ 505, 10 de marzo de 1938, pp. 6178-6181. 
una renovación metodológica y actualización pautada por el Congreso Nacional de Derecho civil de $1946^{39}$.

En definitiva, el Nuevo Estado se pertrechó de una teoría uniformada de la nación ${ }^{40}$, pero no basada en el estatalismo burgués, sino en la estructura jerárquica del Mando propia del totalitarismo ${ }^{41}$. Todos los derechos son ya un fantasma; el valor de la justicia, en una versión trasnochada de su catolicismo clásico, resulta la careta que los sustituye, tal y como hace el caudillaje nacionalsindicalista con la soberanía de la nación ${ }^{42}$.

\section{AUTONOMÍA REGIONAL, GARANTÍAS INDIVIDUALES Y DERECHOS SOCIALES EN LA II REPÚBLICA.}

La II República abordó la cuestión de los derechos regionales o de los organismos naturales o las comunidades históricas desde una posición axiológica distanciada del primer republicanismo. Si en este habian prevalecido los derechos individuales, en el segundo republicanismo serán los derechos colectivos (sociales) los sobresalientes. Pero hubo en el esfuerzo del segundo republicanismo por digerir los derechos regionales un principio fundamental, común y resistente por lo demás en todo republicanismo, un catalizador común de los derechos individuales y de los derechos sociales, cual el de la igualdad jurídica, con el que va a tenerse que contrastar el reconocimiento de la

39 Pueden colegirse las variables del tratamiento normativo de los derechos forales entre el Estado liberal y el Estado franquista en Enrique Gacto Fernández, Juan Antonio Alejandre García y José María Garcia Marín, El Derecho histórico de los pueblos de España (temas para un curso de

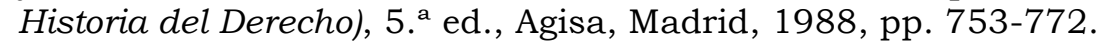

40 Sobre la idea de nación en la politología y filosofía jurídica del franquismo, José Manuel Cuenca Toribio, Nacionalismo, franquismo y nacionalcatolicismo, Actas, Madrid, 2008, pp. 92-112.

${ }^{41}$ Fernando Molina y José A. Pérez, "Violencia y nacionalización de masas: el franquismo", en Félix Luengo Teixidor y Fernando Molina Aparicio (eds.), Los caminos de la nación. Factores de nacionalización en la España contemporánea, Editorial Comares, Granada, 2016, p. 136, refieren sus características nacionalizadoras: "1) existe una nación primordial, cuya definición es cultural (católica) y cuenta con una sólida tradición política en la que convergen culturas politicas variadas (tradicionalismo, integrismo, monarquismo, conservador, falangismo); (2) esta nación es sagrada pues está amparada por la divinidad y, consiguientemente, tiene derecho de propiedad sobre su cuerpo social, cuyas libertades y derechos están subordinados a los intereses de la religión, que es su esencia (de ahí que esas libertades y derechos sean concebidos desde un plano preliberal, como 'fueros'); (3) es imaginada y 'narrada' de acuerdo a una trama épica de pérdida y salvación [...] 4) el paso siguiente a esta conquista es una acción institucional general en el conjunto de espacios públicos, semipúblicos y privados para promover el lenguaje, la identidad cultural, la preeminencia demográfica, el bienestar social y la hegemonía política de los miembros de la nación verdadera; (5) esta acción se formaliza mediante un repertorio de politicas nacionalizadoras justificadas como remediadoras y compensadoras del maltrato practicado sobre la nación 'verdadera' por el Estado liberal y laicista; (6) el proyecto (re)nacionalizador es completado por una intensa movilización social, en este caso de estética fascista y militarista y contenido religioso [...] 7) estas prácticas movilizadoras y simbólicas adquieren perfiles formales e informales, con el fin de alimentar un proyecto regenerador (recatolizador), y son impulsadas tanto por instituciones estatales como no estatales, públicas como semipúblicas”.

42 "Ley Fundamental de 17 de mayo de 1958 por la que se promulgan los principios del Movimiento Nacional", BOE, n. ${ }^{\circ} 119,19$ de mayo de 1958, pp. 4511-4512; II: "La Nación española considera como timbre de honor el acatamiento a la Ley de Dios, según la doctrina de la Santa Iglesia Católica, Apostólica y Romana, única verdadera y fe inseparable de la conciencia nacional, que inspirará su legislación”. 
autonomía y el autogobierno como instrumentos que la Constitución de 1931 instituye para encauzar el reconocimiento de las singularidades jurídicas territoriales y concretamente de aquellas comunidades históricas más encendidas por el avance ideológico del nacionalismo: Cataluña, Galicia y el País Vasco.

La idea de las regiones autónomas en la Constitución de $1931^{43}$ tiene, quizá, una raigambre iusracionalista inesperada (si no se considera deudora del experimento del primer republicanismo, en otros puntos ya tan lejano). Inesperada por cuanto no hay en ella derechos individuales ni derechos naturales, sino derechos (constitucionales) atribuibles a (una República democrática de) trabajadores (artículo $1^{\circ}$ ), término que envuelve al individuo en clase, en socialización, que prescinde del sujeto (individuo) transformándolo en calificativo, pero no calificativo del derecho (evaporado como categoria) sino, extrañamente (y evocando la perspectiva positiva de la constitucionalización y legalización), de su protección: "garantías individuales". En realidad, los derechos, sea su origen individualista o su advenimiento socialista ("Garantías individuales y políticas", "Familia, economía y cultura"), pierden fronteras al vincularse a un sujeto socializado y clasificado en su calidad de trabajador; como esta vinculación se produce en el texto constitucional, la constitucionalización de los derechos excluye todo iusnaturalismo. Y sin embargo, como decía, aún existe un aliento iusracionalista aplicado al concepto de autonomía, porque el proceso constitucional de configuración de las regiones autónomas, con sus estatutos, obedece a un camino inductivo que recuerda la esencia individual del poder: la asamblea de ayuntamientos y el plebiscito regional alimentan el poder legislativo desde la sociedad como base, y la aprobación de las Cortes (arts. 11-12) garantiza una unidad garantista de la igualdad formal (desvinculada del privilegio) en cualquier excitación de un régimen estatutario. Por otra parte, la eventual afección de la autonomía a los ciudadanos, en la medida en la que implica un ámbito regional de poder, se afronta, como la constitucionalización de los derechos garantizada mediante una superioridad jerárquica de la Constitución, con un "amparo de garantías individuales" que resulta ser competencia del Tribunal de Garantías Constitucionales (artículo 121.b): se advierte que, en este momento técnico, las garantías, aunque no se presenten como derechos, mantienen significativamente, en esa fórmula redundante de "amparo de garantias" que parece evitar adrede su burguesa nominación de derechos, el calificativo de la individualidad.

La discusión en Cortes sobre Estatuto de Cataluña permitió contemplar dos sensibilidades politicas en torno al concepto de autonomía regional.

Para sus defensores, 1) la autonomía desconectaba de su interpretación como privilegio y obedecía a la existencia de un derecho de autodeterminación del pueblo catalán; 2) se legitimaba como pacto entre la región autónoma y el Estado, en virtud de distintas titularidades de soberanía, 3) pero también podia comprenderse desde una concepción estrictamente organicista del Estado, y 4) no se consideraba incompatible con el fortalecimiento de la unidad de España. En efecto,

43 "Constitución de la República Española", en Gaceta de Madrid, n. ${ }^{\circ}$ 344, 10 diciembre 1931, pp. 1578-1588. 
1) El diputado galleguista Alfonso Rodríguez Castelao teorizó rudimentariamente sobre la conversión del privilegio (captado como razón de la crítica implícita a todo derecho de una comunidad histórica) en un derecho de autodeterminación, asegurando que el privilegio de la autonomía no era sino una percepción resultante de las reivindicaciones regionales forzadas por los obstáculos constitucionales ${ }^{44}$.

2) El diputado Amadeo Hurtado, de Esquerra Republicana de Catalunya, comprendía el Estatuto como un pacto entre la región autónoma y el Estado, concibiendo la estructura federal, y por elevación el "sentimiento de universalidad" (en principio coincidente con el socialismo), como un proceso político de origen popular, contra el diseño estatal (o superestatal del socialismo $)^{45}$.

3) E1 diputado independiente Jerónimo García Gallego afirmó la constitucionalidad de la comprensión jurídica de la autonomía como Estado, al considerar que este nace de una estructura institucional legislativa y gubernativa que la propia autonomía ciertamente venía a consolidar, y es cierto que consideraba esta estatalización como universal o igual para todas las regiones, aunque su hincapié en la federación como no efectiva, sino potencial ${ }^{46}$, dejaba sin explicar cuál es la naturaleza jurídica propia del Estado que engloba ese surtido desigual de Estados potenciales y Estados germinados. Con muy parecida aproximación oblicua, Raimundo d'Abadal, de la Lliga Regionalista, evitó la cuestión conceptual del estatismo y el nacionalismo, de la soberanía y la autonomía, dando por bueno el esquema constitucional, y en particular la definición de la soberanía popular, para concluir en que si el ejercicio de esa soberanía correspondía a los órganos del Estado, conforme a una determinada jerarquía, de esta organicidad formaba parte la estructura autonómica ${ }^{47}$. Como

44 Diario de Sesiones de las Cortes Constituyentes de la República Española (= DSC), legislatura 1931-1933, 12-5-1932, n. ${ }^{\circ}$ 164, pp. 5553-5554: "Los parlamentarios que pertenecemos al partido galleguista consideramos legitimas todas las aspiraciones del pueblo catalán [...] Al confeccionar el Código constitucional no se ha querido cambiar la estructura del Estado y se han puesto demasiados obstáculos a las aspiraciones regionales; por eso resulta que la autonomía de Cataluña parecerá un privilegio [...] Ya hemos opinado que Cataluña tiene derecho a su autodeterminación [...]".

45 DSC, legislatura 1931-1933, 20-5-1932, n. ${ }^{\circ}$ 169, pp. 5712, 5715: "El Estatuto es un pacto entre la región autónoma y el Estado. [...] Se me ha dicho varias veces que el partido socialista iba a ser aquí vocero del antiguo patriotismo español. [...] el criterio universalista del socialismo tiende aquí, como en todo el mundo, a estructurar la Humanidad en una Federación mundial representada en un super Estado [...] son, precisamente, las Federaciones en que se respeta la libre voluntad de los pueblos las que responden al sentimiento de universalidad".

46 DSC, legislatura 1931-1933, 19-5-1932, n. ${ }^{\circ}$ 168, pp. 5683, 5685: "Pero ¿cómo puede negarse que la República española en su Constitución admite la posibilidad jurídica de Estados autónomos? [...] Una región que puede tener Cortes propias, que puede tener Gobierno propio, ¿no es un Estado? [...] Quedamos, pues, en que la Constitución es de tipo federalista, no federal, en acto, en ejercicio, con carácter universal para todas las regiones de España, sino federable, federal potencialmente para todas las regiones que quieran erigirse en Estados autónomos [...]”.

47 DSC, legislatura 1931-1933, 13-5-1932, n. ${ }^{\circ}$ 165, p. 5589: "Frente al Estatuto [...] nosotros, los individuos de la Lliga regionalista, estamos en la posición de aceptarlo, de apoyarlo y de defenderlo. Nosotros no hemos intervenido en su elaboración. Los vaivenes de la política han hecho que estuviésemos apartados de la Asamblea de la Generalidad cuando el problema se puso sobre la mesa de la misma, se discutió y se redactó el proyecto de Estatuto [...] Ya no hemos de tratar aquí de lo que significan los conceptos de estatismo o de nacionalismo, de soberanía o de 
decía el diputado republicano federalista José Franchy Roca, si el Estado ejerce la soberania, la ejercen tanto el "Estado nacional" como "los Estados que lo integran"48.

4) La concepción del federalismo pactista a menudo fue presentada como una solución favorecedora de la solidaridad de las regiones en el seno del Estado. De servicio "a los demás", por parte de la autonomia, hablaba el diputado socialista catalán Rafael Campalans, cuya idea de nación no iba más atrás de la monarquía borbónica, aunque por otro lado equilibraba la autonomía mediante la necesidad de la adaptación a la Constitución ${ }^{49}$. Con el mismo contraste del "experimento peligroso" de la monarquía borbónica, el diputado Luis Companys, de Esquerra Republicana de Catalunya, consideró que un régimen autonómico favorecería el fortalecimiento de la unidad de España50.

La corriente política contraria a la concepción anterior de la autonomía regional defendía, 1) en una cierta atmósfera constante de pesimismo en relación con la solución del problema, 2) la inconstitucionalidad de la noción de Estado autonómico, 3) y la viabilidad constitucional de la región autónoma, pero negando cualquier interpretación pactista, así como la posibilidad de una soberania alternativa a la de la nación española, y entendida la construcción autónomica siempre como habilitada por la concesión estatal.

1) El pesimismo subyacía en el análisis del problema regional. Así, el diputado nacional-republicano Felipe Sánchez Román consideraba la "forma autonómica" como una "anomalía" que solo podía tener dos resultados: la unidad o la separación 51. Por su parte, el diputado radical Alejandro Lerroux discriminaba entre la buena voluntad de los actuales diputados catalanes en

autonomía, de desintegración del Estado o de división del territorio del mismo, no; todo esto está resuelto en la Constitución. El principio capital de ésta es el de que la soberanía de los Poderes del Estado reside en el pueblo y se ejerce por los órganos del Estado, por todos los órganos del Estado, según su jerarquía, según su situación, según las necesidades que tienen que llenar y según los problemas que tienen que resolver".

48 DSC, legislatura 1931-1933, 19-5-1932, n. ${ }^{\circ} 168$, p. 5679: “[...] la soberanía no es un derecho subjetivo del Estado [...] la soberanía es —en pueblos democráticos así tenía que ser- un atributo de la comunidad misma, y lo que corresponde al Estado, como representante de esta comunidad, es en rigor, única y exclusivamente, el ejercicio de ese poder directivo [...] tan Estado es el Estado nacional como lo son los Estados que lo integran: municipios, provincias, regiones".

49 DSC, legislatura 1931-1933, 13-5-1932, n. ${ }^{\circ}$ 165, pp. 5583-5584: "En este momento, como Diputados de Cataluña - lo dijo ya mi ilustre jefe el Sr. Companys—, nuestra posición es muy sencilla: ante el debate del Estatuto, nosotros pedimos su simple adaptación a la Ley Constitucional. [...] Cataluña reclama una autonomía, no para desentenderse de los demás, sino precisamente para servir a los demás. [...] Sé que la nación ha empezado a vivir en el siglo pasado $[\ldots] "$.

50 DSC, legislatura 1931-1933, 6-5-1932, n. ${ }^{\circ}$ 161, p. 5474: "En el fondo del pensamiento de S. S. creo que lo que late, aunque S. S. lo ha negado, quizá por cortesía o galantería, es una desconfianza a la madurez y a la capacidad de Cataluña. Pues bien, nosotros decimos que Cataluña está preparada [...] y decimos, además, que con ella empezaremos la instauración de un régimen autonómico, que contribuirá a fortalecer la unidad de España de manera más firme y segura que lo ha hecho el experimento peligroso por que hemos pasado de la monarquía unitaria borbónica".

51 DSC, legislatura 1931-1933, 12-5-1932, n. ${ }^{\circ} 164$, p. 5549: "Esta forma autonómica, y que, por cierto, se afirma, yo creo con razón que es anómala, porque no es permanente, sino fugaz e histórica, porque camina inexorablemente hacia la 'unidad' o a la 'separación' [...]”. 
Madrid y la sensibilidad, que barruntaba no muy compenetrada con España, de los futuros diputados catalanes ${ }^{52}$. Asimismo, el diputado José Ortega y Gasset, de la Agrupación al Servicio de la República, juzgaba que el problema catalán "no se puede resolver", y aportaba una apreciación sociológica de importancia, cual la división social "antagónica" de Cataluña, que impedía considerar ideología única el "nacionalismo particularista", para afirmar no obstante al fin, y como un efecto matizador de su inicial pesimismo, que el problema "es bien posible conllevarlo" 53 , de lo que resultaba manera precisamente la fórmula estatutaria.

2) La inconstitucionalidad de la concepción de la región autónoma como un Estado autónomo fue claramente defendida por el diputado republicano Luis Bello ${ }^{54}$.

3) La negación de un supuesto pacto entre el Estado y "la personalidad regional" fue expresada por el diputado José María Gil Robles, del Bloque Agrario, excluyendo la posibilidad de una "nación autónoma" y atribuyendo la autonomía al reconocimiento del Estado ${ }^{55}$. Otro diputado del mismo partido, Tomás Alonso de Armiño, al elidir la idea de pacto por lo que entraña de relación entre entidades iguales, y afirmar en consecuencia la unidad de la soberanía de la nación española, añadía dos consideraciones políticas interesantes: la negación de un supuesto "asimilismo" castellano, y la observación de que la supuesta desigualdad contradicha por el pactismo procede en realidad de la articulación nacionalista de una soberana "voluntad de Cataluña" de la que sería muestra ese Estatuto, con una determinada concepción del derecho de autodeterminación respecto de la cual se exigía con agresividad la adhesión estatal ${ }^{56}$. Felipe Sánchez

52 DSC, legislatura 1931-1933, 20-5-1932, n. ${ }^{\circ}$ 169, p. 5722: "Es un Estatuto maximalista [...] ¿estáis seguros de que mañana, cuando convoquéis al pueblo catalán a las elecciones, de las cuales han de salir la Generalidad y el Parlamento catalán, seréis vosotros mismos los elegidos, que por el hecho de haber venido aquí os habéis compenetrado con España, que esta es la magia del corazón de España, esta es la simpatía extraordinaria de Madrid, que convierte en españoles a los separatistas y a los más antagónicos en madrileños [...]".

53 DSC, legislatura 1931-1933, 13-5-1932, n. ${ }^{\circ}$ 165, pp. 5575-5577: “Digo, pues, que el problema catalán es un problema que no se puede resolver, que sólo se puede conllevar; que es un problema perpetuo, que ha sido siempre, antes de que existiese la unidad peninsular y seguirá siendo mientras España subsista [...] ¿Qué es el nacionalismo particularista? Es un sentimiento de contornos vagos, de intensidad variable [...] el afán de quedar fuera, exentos, señeros, intactos de toda fusión, reclusos y absortos dentro de sí mismos. [...] ¿Quiere decir, por lo pronto, que todos los catalanes sientan esa tendencia? De ninguna manera. Muchos catalanes sienten y han sentido siempre la tendencia opuesta [...] Muchos, muchos catalanes quieren vivir con España. [...] Es el eterno y conocido mecanismo en el que con increíble ingenuidad han caído los que aceptaron que fuese presentado este Estatuto. ¿Qué van a hacer los que discrepan? Son arrollados [...] Pero una vez hechas estas distinciones, que eran de importancia, reconozcamos que hay de sobra catalanes que, en efecto, quieren vivir aparte de España [...] Si el sentimiento de los unos es respetable, no lo es menos el de los otros, y como son dos tendencias perfectamente antagónicas, y no comprendo que nadie, en sus cabales, logre creer que problema de tal condición puede ser resuelto de una vez para siempre. [...] En cambio, es bien posible conllevarlo".

54 DSC, legislatura 1931-1933, 6-5-1932, n. ${ }^{\circ} 161$, p. 5457, en relación con la primera redacción del artículo $1 .^{\circ}$ del Estatuto de Cataluña, que rezaba: "Cataluña es un Estado autónomo dentro de la República española”.

55 DSC, legislatura 1931-1933, 10-6-1932, n. ${ }^{\circ} 181$, p. 6157: "El Estado reconoce unos derechos, pero no pacta con quienes los tienen: el Estado reconoce una personalidad regional, pero no pacta con una Nación autónoma, independiente".

56 DSC, legislatura 1931-1933, 12-5-1932, n. ${ }^{\circ}$ 164, pp. 5557-5558: “[...] el hecho de que después de muchos siglos de constituída la unidad española subsista aún en todas partes la 
Román rechazaba también la idea de pacto al considerar que la autonomía regional "es obra de la voluntad del Estado" como forma de descentralización y siempre a salvo "la unidad integral del Estado español"57. Igualmente, José Ortega y Gasset comprendió la autonomía como "cesión de poderes", otorgados (y reversibles) por el Estado soberano, eliminada la posibilidad de la noción de un "poder" directamente emanado del pueblo catalán58.

Por lo tanto, la ley de 11 de septiembre de 1932 que aprobó el Estatuto de Cataluña no asumió inercialmente una posición políticamente uniforme, sino que cristalizó, contra argumentos discrepantes, una posición político-jurídica propia del segundo republicanismo ${ }^{59}$. Una posición politico-jurídica que, en relación con el problema de la autonomía regional, se reduce a dos criterios, recogidos en su

diferencia de legislación de derechos civiles que perdura en los países forales, y que el caso de que podéis todavia hablar de un hecho diferencial que entre vosotros y nosotros existe, están demostrando de una manera palmaria que la politica de Castilla no ha estado inspirada en propósitos asimilistas. [...] Os presentáis aquí diciendo que traéis un Estatuto que ha nacido de la autodeterminación de Cataluña y que el poder de Cataluña nace de su voluntad. Venís aquí, por lo tanto, con un desconocimiento de la soberanía nacional que encarna esta Cámara, presentando soberanía contra soberanía, y eso no lo podemos tolerar. En España no hay más que una soberanía, la soberanía de la Nación española, y un órgano de esa soberanía, que son estas Cortes. [...] Es más; no venís sólo a pactar de igual a igual, sino que venís como si fuéramos un pueblo vencido, a dictar las condiciones que queréis que aceptemos casi sin discusión. Ya sé yo que ese lenguaje no se va a oír en esta Cámara, pero representación tan autorizada de Cataluña como es el propio Presidente de la Generalidad, está diciendo un día y otro que la voluntad de Cataluña ha de prevalecer, que las Cortes se someterán a la voluntad de Cataluña y que si no se someten, los catalanes seguirán luchando por que su voluntad prevalezca. Es decir, que venís a decir a los españoles: 'Ahí tenéis lo que nosotros queremos que sean el Estatuto fundamental de Cataluña y la organización del Estado español, para que vosotros lo aceptéis, porque si no los aceptáis, el problema catalán no estará resuelto y nosotros seguiremos trabajando para que la voluntad de Cataluña prevalezca'. No se puede plantear así el problema”.

57 DSC, legislatura 1931-1933, 12-5-1932, n. ${ }^{\circ} 164$, p. 5549: "Lo primero que de todo resulta es, a mi juicio, que la organización de estas autonomias regionales es obra de la voluntad del Estado; que no hay pacto [...] Es el Estado español, es la ley política fundamental, la que, escogiendo para su organización uno de los sistemas, dice: No quiero ser ni organizarme como Estado federal [...] si no es un Estado federal ni de tendencia federativa, si no es más que un Estado que busca en una descentralización autonómica la manera de organizar sus regiones, sin perjuicio de la unidad integral del Estado español, yo no me explico entonces cómo al crear estas autonomías regionales, en general bajo el patrón de la Constitución y en concreto cuando cada una lo solicite, ha podido pensarse ni por un momento en la doctrina del pacto, el concierto de poder a poder, que brota en los labios de la Comisión parlamentaria”.

58 DSC, legislatura 1931-1933, 13-5-1932, n. ${ }^{\circ}$ 165, pp. 5578-5579: "Y conste que autonomía significa, en la terminología jurídicopolítica, la cesión de poderes; en principio no importa cuáles ni cuántos, con tal que quede sentado de la manera más clara e inequívoca que ninguno de esos poderes es espontáneo, nacido de sí mismo, que es, en suma, soberano, sino que el Estado lo otorga y el Estado lo retrae y revierte a él. Esto es autonomía. Y en ese plano, reducido así el problema, podemos entendernos muy bien [...] Es, pues, preciso que este partido [socialista], que es un partido de clase, al hacerse partido de gobierno, nos vaya enterando de cómo logra articular su interés de partido de clase con el complejo y orgánico interés nacional [...] no podemos, por eso, nosotros aceptar que en él se diga: 'El Poder de Cataluña emana del pueblo.' La frase nos parece perfecta, ejemplar; define exactamente nuestra teoría general política; pero no se trata, sin distingos que fueran menester del pueblo de Cataluña aparte, sino del pueblo español, dentro del cual y con el cual convive, en la raíz, el pueblo catalán”.

59 Es el diagnóstico también de Francisco Tomás y Valiente, "Soberanía y autonomía en las Constituciones de 1931 y 1978”, en Aquilino Iglesia Ferreirós (coord.), Autonomía y soberanía. Una consideración histórica, Marcial Pons, Madrid, 1996, pp. 120-123. 
artículo primero: la concepción intraestatal de la autonomía regional y el engarce constitucional estatutario de la autonomia regional intraestatal ${ }^{60}$. Se trata de una estructura jurídica armónica con la filosofia política del marxismo ${ }^{61}$.

Este criterio autonómico cubría formalmente de manera completa la existencia y el desarrollo legítimo de los derechos de los organismos naturales históricos: no era una cláusula de incorporación de una realidad jurídica extraña, sino la concesión de un orden técnico para la juridificación de una realidad excéntrica. La cobertura formal de estos derechos regionales tenía que complementarse, además, con una estricta constitucionalización (desestatutaria) de los derechos individuales: una calificación llamativamente recuperada en este brete (frente a su marginación, por liberal, propiciada por la ideología socialista del trabajador y sus garantías).

Por supuesto, no faltaron en Cortes diputados defensores de la coexistencia de los derechos individuales con los derechos de las regiones u otras personalidades jurídicas, como sostenía el independiente Jerónimo García Gallego ${ }^{62}$. Enlazando con el organicismo advertido en la estructura autonómica, para Nicolau d'Olwer, de la Lliga Regionalista, el estatuto debía ser comprendido como una "carta de garantía" de los derechos autonómicos, de carácter políticoadministrativo63. Amadeo Hurtado, de Esquerra Republicana de Catalunya, afirmaba la coexistencia de los derechos individuales populares -apuntando con el calificativo (habilitado conforme al concepto constitucional de soberanía popular) hacia una colectivización homogénea- con los derechos y libertades de los organismos naturales, en el bien entendido de que la concesión y limitación de estos correspondía al Estado64. El apunte de la aceptación del monopolio estatal podría considerarse el precio de la ampliación del catálogo de derechos, de

60 Ley de 11 de septiembre de 1932, en Gaceta de Madrid, 21 septiembre 1932, n. ${ }^{\circ}$ 265, pp. 2090-2094. Artículo 1. : "Cataluña se constituye en región autónoma dentro del Estado español, con arreglo a la Constitución de la República y el presente Estatuto”.

61 Santiago Armesilla, El marxismo y la cuestión nacional española, El Viejo Topo, Barcelona, 2017, pp. 161-168, 207-213, 238-241, 288-290, analiza el pensamiento marxista-leninista: el "centralismo político del Estado obrero", la "República democrática" unitaria y centralista como "acceso más próximo a la dictadura del proletariado" y la compatibilidad entre centralismo y autonomismo con descarte del federalismo y de la confederación.

62 DSC, legislatura 1931-1933, 19-5-1932, n. ${ }^{\circ}$ 168, p. 5688: "No hay que confundir la autoridad del Estado con los derechos del individuo, de las regiones y de todas las personalidades juridicas de cualquier clase que sean”.

63 DSC, legislatura 1931-1933, 19-5-1932, n. ${ }^{\circ}$ 168, pp. 5693, 5695: "Para nosotros la Constitución y el Estatuto están absolutamente compenetrados. [...] ¿Es que porque, según el Estatuto, no haya en Cataluña un representante nombrado por el Estado, el Estado está ausente de Cataluña? [...] El Estatuto, en definitiva, se diga o no se diga, es un complemento directo de la Constitución; los Estatutos son la Carta de garantía de unos derechos politicoadministrativos de los territorios autónomos [...]".

64 DSC, legislatura 1931-1933, 20-5-1932, n. ${ }^{\circ} 169$, p. 5710: “[...] ahora que la democracia de atómica se convierte en orgánica; ahora que, además de los derechos populares que asisten al hombre como individuo, ha nacido la idea de que el hombre tiene también derechos en función del organismo natural al cual pertenece para realizar un fin para la vida y que estos organismos tienen a su vez sus derechos y deben tener también su libertad, se levanta otra vez la vieja teoría de la Carta otorgada, y nos dice: 'No, no sois vosotros, los representantes de esos pueblos, los que debéis formular el Estatuto de vuestros derechos; es el Estado, actual representante de la antigua soberanía, el que dirá la extensión y el límite de esos derechos y se reservará la facultad de concederlos, de controlarlos y de quitarlos, si le place, una vez los haya otorgado". 
individuales a orgánicos, o bien del reconocimiento, en palabras del diputado republicano radical Eduardo Ortega y Gasset, de la "preexistencia de personalidades naturales" junto a los "derechos constitucionales"; cierto que en esta forma de equilibrio entre unos derechos y otros es más precario el pulso de los individuales, porque aunque sea la Constitución la norma que reconoce y limita los derechos de los organismos naturales, tal reconocimiento implica su preconstitucionalidad ${ }^{65}$, una característica que el iusnaturalismo racionalista habría predicado tan solo de los derechos individuales y que implicaba, en el fondo, no solo su preconstitucionalidad, sino también la viabilidad de su supraconstitucionalidad.

Contra este equilibrado punto de encuentro entre regionalistas y republicanos, demostrativo de cómo los derechos individuales habian encajado desde hacía tiempo el golpe de los derechos colectivos, la preservación de la preconstitucionalidad como don de los derechos individuales será sostenida, paradójicamente (si se atiende a su esencia racionalista, muy lejos de la opción de los derechos de la nación del conservadurismo liberal) por la derecha política. El diputado Joaquín Fanjul, de la Unión Militar Española, consideró el reconocimiento de los derechos individuales como previo a la autonomía municipal y regional ${ }^{66}$, sin caer en la cuenta de que este razonamiento permitia en su enlace la regionalización de los derechos individuales. Con mejor protección constitucional de los derechos individuales, el diputado Alfonso García Valdecasas, futuro miembro de Falange Española, expulsa de los estatutos toda referencia a los derechos individuales, por considerarlos competencia exclusiva del Estado, y en consecuencia materia estrictamente constitucional ${ }^{67}$. El diputado Miguel Maura, de Derecha Liberal Republicana, desarrollaba esta misma idea del amparo estatal de los derechos de la ciudadanía contra el riesgo de una ausencia del Estado en Cataluña que derivase tanto en "pequeñas vejaciones" como en una

65 DSC, legislatura 1931-1933, 27-5-1932, n. ${ }^{\circ}$ 173, p. 5847: “[...] la República española [...] otros tantos postulados han predeterminado todo su texto constitucional [...] Su resolución en las normas constitucionales venía ya determinada por tres factores: uno, el del respeto a los derechos constitucionales; otro, el de la aceptación del derecho de gentes [...] y el último, que ha predeterminado el derecho constitucional, es el de la preexistencia de personalidades naturales; personalidades naturales que han quedado reconocidas explícitamente en la Constitución. [...] es indudable [...] que los organismos naturales tienen un derecho que es anterior a la Constitución, sin que ésta haga nada más que reconocerlo. [...] el derecho permanece inminente en el organismo natural, si bien sólo lo pueda ejercitar hasta el límite mismo en que la Constitución permite el ejercicio de ese mismo derecho".

66 DSC, legislatura 1931-1933, 10-6-1932, n. ${ }^{\circ} 181$, p. 6168: "Pero es que además en el dictamen de la Comisión, lo mismo que en la Constitución, se ha empleado un procedimiento analitico, procedimiento que, por ser analitico, es separador, desmembrador, diseminador, cuando el procedimiento, que nace además del reconocimiento de la libertad del individuo y va al de las colectividades, pasando por el Municipio, tiene que ser procedimiento sintético, que es constructor, unificador y aglutinante; por eso creo que os debiais haber ido primero al reconocimiento de los derechos individuales; después, a la autonomía municipal, y de allí, por el mismo procedimiento, a la autonomía regional. Desenvuelto este procedimiento sintético dentro del concepto económico que yo he trazado, no habría, por parte del resto de España, la sensación de que se va a poner a Cataluña en el camino de su independencia [...]".

67 DSC, legislatura 1931-1933, 28-6-1932, n. ${ }^{\circ}$ 190, p. 6512: “[...] propongo la supresión de la referencia a los derechos individuales, porque con arreglo a la Constitución misma, son de la exclusiva competencia del Estado español la legislación y ejecución directa de las materias siguientes: primero, derechos y deberes constitucionales". 
"ciudadanía privilegiada", la catalana, de "doble privilegio" y "doble derecho"68. De parecida manera, el diputado reformista Melquiades Álvarez rechazaba el "minimum" conforme al cual los catalanistas comprendian los derechos individuales 69 , y en el que por lo demás se adivinaba tanto la asunción estatutaria de los derechos individuales (contra el monopolio constitucional) cuanto la percepción maurista de un "doble privilegio".

La posición final oficial del segundo republicanismo, en el Estatuto de Cataluña, se asemejó más al contenido de estas últimas críticas que a la postura equilibrista de regionalistas y ciertos republicanos, lo que no debe extrañar, porque armonizaba mejor con la concepción de la autonomía intraestatal con engarce constitucional. La solución que se impuso consistió en constitucionalizar la fijación de los derechos individuales para toda la República española, con una mención expresa tanto de la imposibilidad estatutaria de cualquier regulación "con diferencia de trato", como de la prohibición de que el resto de los españoles pudiera adolecer en Cataluña de "menos derechos"70.

Fueron pues, la autonomía intraestatal con engarce constitucional y la constitucionalización de los derechos individuales, un criterio binómico proclamado con acendrado convencimiento republicano. La prueba reside en que

68 DSC, legislatura 1931-1933, 6-5-1932, n. ${ }^{\circ}$ 161, pp. 5451-5452: "Y vamos ahora a lo que es más fundamental, a la obligación ineludible que tiene el Estado de amparar a todos sus ciudadanos en el ejercicio de sus derechos. Supongo que este postulado nadie podrá discutirlo. Pues bien, lo primero que yo me encuentro al examinar con esta lupa el dictamen de la Comisión, es esto: si este dictamen se aprueba, el Poder público como tal Poder público, el Estado como Poder público, se retira integramente de Cataluña [...] Pues bien; ¿qué pasaria si un buen día hubiera en el Gobierno de la Generalidad un partido politico, un sector de opinión catalana que, por vehemencia, por insensatez o por lo que fuera, intentara, y realizara, una política de agresión, de molestia, de ofensa a lo que no fuera de sentimiento genuinamente catalán dentro de Cataluña, en esa forma, que se puede hacer casi impalpable, de pequeñas vejaciones, pequeñas multas, trabas a los negocios, registros domiciliarios? Los ciudadanos, que no fuesen catalanes, que estuvieran sometidos a esta tortura, se preguntarían: 'Bueno, ¿y a quién nos dirigimos? [...] pues esos ciudadanos se encontrarian con que tendrian que acudir al general de la división o al comandante de Marina, porque, claro, les queda el camino del recurso contencioso, pero después de haber pasado por toda la gama del papel sellado y de los Tribunales catalanes; y cuando todo esto esté terminado, entonces podrán venir aquí, al Supremo, a reclamar. [...] a mi juicio, hay dos resortes, dos herramientas indispensables: una, la unidad legislativa que somete a todos los ciudadanos a una misma ley, y otra, la soberanía fiscal, porque si el Estado no conserva la soberanía fiscal no puede hacer politica social, ni politica económica, ni nada que se le parezca. / ¿Qué hay en el Estatuto de todo esto? Pues lo primero que se tropieza uno es con que se crea una ciudadanía privilegiada, de ciudadanos de cuota; se crea la ciudadanía catalana, y como son ciudadanos catalanes y además son ciudadanos españoles, resulta que los ciudadanos allí tienen el doble privilegio y el doble derecho, y cuando vienen aquí siguen siendo ciudadanos españoles, y los ciudadanos españoles llegan a Cataluña y no pasan de ser ciudadanos españoles, no son ciudadanos catalanes".

69 DSC, legislatura 1931-1933, 2-6-1932, n. ${ }^{\circ} 176$, p. 5987: “[...] porque declara el art. 8. ${ }^{\circ}$ que los derechos individuales de los ciudadanos catalanes serán, como mínimum, los fijados por la Constitución de la República española. Es decir, que en Cataluña puede haber ciudadanos que gocen de derechos individuales superiores al resto de los españoles. Puede haberlos, porque habláis 'como minimum' de los derechos individuales”.

70 Ley de 11 de septiembre de 1932, cit., artículo 3. ${ }^{\circ}$ "Los derechos individuales son los fijados por la Constitución de la República española. La Generalidad de Cataluña no podrá regular ninguna materia con diferencia de trato entre los naturales del país y los demás españoles. Estos no tendrán nunca en Cataluña menos derechos de los que tengan los catalanes en el resto del territorio de la República". 
la estricta constitucionalización de los derechos individuales y la autonomía intraestatal con engarce constitucional serán también los principios del segundo republicanismo recogidos en el Estatuto de Galicia de 193371. En el Estatuto del País Vasco de 1936, aprobado definitivamente una vez acordada la declaración de urgencia pedida por el Gobierno y tras la aprobación del dictamen de la comisión sin discusión para su sometimiento a la cámara ${ }^{72}$, figuró la autonomía intraestatal con engarce constitucional, pero sin ninguna referencia o remisión a la constitucionalización de los derechos individuales ${ }^{73}$-un silencio que, dados los antecedentes autonómicos, no cabía interpretar sino en la constancia de su exclusiva constitucionalización ${ }^{74}$.

Quizá, a la vista del perfil de esta normativa, podría afirmarse, a la postre, que la intraestatalización que afecta a la autonomía como cauce de los derechos históricos, así como el engarce constitucional, encuentran su expresión concreta $\mathrm{y}$ mejor en los derechos individuales, que no son los derechos naturales preconstitucionales de la experiencia demócrata y del primer republicanismo, ni los derechos nacionales del conservadurismo liberal y aun primorriverista, pero sí unos derechos estrictamente constitucionales de predicación social que, frente a colectivos exógenos de derechos, recuerdan la raigambre de la igualdad y la soberanía del pueblo uniforme de trabajadores.

\section{LA CONSTITUCIÓN DE 1978 Y LA POLINACIONALIZACIÓN DE LOS DERECHOS PROVINCIALES HISTÓRICOS.}

La tensión entre derechos constitucionales y derechos de los organismos naturales históricos se replanteará en la monarquía parlamentaria que instaura la Constitución de $1978^{75}$, pero de una manera muy distante de los principios

71 Decreto relativo al proyecto de Estatuto de Galicia, en Gaceta de Madrid, 31 mayo 1933, n. ${ }^{\circ}$ 151, pp. 1545-1546: Estatuto de Galicia que la Asamblea Regional de Ayuntamientos celebrada en Santiago de Compostela durante los días 17, 18 y 19 de diciembre de 1932, acordó proponer a la votación de los electores, conforme al artículo 12 de la Constitución, Tipografia El Eco de Santiago, 1932. Artículo 1. ${ }^{\circ}$ : "Galicia se organiza como región autónoma en el Estado español, con arreglo a la Constitución de la República y al presente Estatuto". Artículo 3.2: "Los derechos individuales serán en Galicia los definidos por la Constitución de la República".

72 DSC, legislatura 1936, 1-10-1936, n. ${ }^{\circ}$ 61, p. 20.

${ }^{73}$ Ley de 6 de octubre de 1936, en Gaceta de Madrid, 7 octubre 1936, n. ${ }^{\circ}$ 281, pp. 211-214. Artículo $1 .^{\circ}$, párrafo primero: "Con arreglo a la Constitución de la República y al presente Estatuto, Alava, Guipúzcoa y Vizcaya se constituyen en región autónoma dentro del Estado español, adoptando la denominación de "País Vasco"'.

${ }^{74}$ En todo caso, como afirma José Luis de la Granja Sainz, Nacionalismo y II República en el País Vasco. Estatutos de autonomía, partidos y elecciones. Historia de Acción Nacionalista Vasca: 1930-1936, Siglo Veintiuno, Madrid, 2008, pp. 486-499, a propósito del procedimiento de aprobación del Estatuto, ese "no era el fin de la política nacionalista, sino su medio hacia la soberanía plena de Euskadi”, lo que quizá podría explicar ese un cierto descuido técnico.

$75 \mathrm{Si}$ la Guerra Civil fue al cabo la confrontación cruenta de las clases uniformadas con su propia visión política excluyente, esto es lo que se trasluce a menudo en la mirada, y en el afán de superarla o trascenderla, de los individuos que la sufrieron, y lo que estará presente en la teoría del consenso (ideológicamente no clasista) de la transición política hacia la Constitución de 1978: lejos en realidad de una reforma aparente, será el tiempo de ruptura con el bucle político de la frustración liberal y su deriva de opciones de clase y finalmente totalitaria, como en un renacido reconocimiento popular (clase media) de la utópica igualdad de derechos de los individuos (derechos ahora fundamentales en vez de naturales), frente a la otra posibilidad, la de una 
establecidos por el segundo republicanismo en su intento pionero de resolver el problema político foralista o nacionalista mediante una estructura autonómica. No se indagará en estas páginas sobre discusiones constituyentes y sensibilidades politicas hacia la vigente norma constitucional, según la síntesis realizada en relación con el pensamiento del segundo republicanismo, porque parece tarea más propia de una interpretación auténtica para cuyo contexto se requiere la formación técnica de los constitucionalistas; interesa antes bien marcar tan solo la distancia respecto de las ideas y soluciones propuestas por el segundo republicanismo, a partir de lo que queda de manifiesto desde luego en la Constitución de 1978, por una parte, y también en la deriva de la formulación de los Estatutos de Autonomía.

La Constitución de 1978 conecta con la Constitución de 1931 al perfilar un sistema autonómico, pero, frente a la republicana autonomía intraestatal con engarce constitucional, establece los siguientes criterios ${ }^{76}$ :

\section{1. ${ }^{\circ}$ Solidaridad entre las partes del territorio español ${ }^{77}$.}

2. ${ }^{\circ}$ Autogobierno como ejercicio del derecho de autonomía de las provincias con "entidad regional histórica"78.

La solidaridad es una pauta resbaladiza susceptible de tergiversaciones y disconformes interpretaciones politicas, que en la práctica poco equilibra. Baste decir, de forma lapidaria, que desde luego no se trata ni remotamente de un principio tan preciso y contundente como el republicano de igualdad jurídica.

La autonomía no es constitucionalmente el resultado de la proyección orgánica del Estado, una concesión estatal de autogobierno ${ }^{79}$ al estilo republicano,

ruptura mas aparente, a la que hubiera conducido el replanteamiento teórico de la tensión clasista constitucional ya experimentada.

76 "Constitución española aprobada por las Cortes en sesiones plenarias del Congreso de los Diputados y del Senado celebradas el 31 de octubre de 1978. Ratificada por el pueblo español en referendum de 6 de diciembre de 1978. Sancionada por S. M. el Rey antes las Cortes el 27 de diciembre de 1978", BOE, n. ${ }^{\circ} 311.1$, 29 diciembre 1978, pp. 29315-29339.

77 Constitución de 1978, cit., artículo 138.1: "El Estado garantiza la realización efectiva del principio de solidaridad consagrado en el artículo 2 de la Constitución, velando por el establecimiento de un equilibrio económico, adecuado y justo entre las diversas partes del territorio español, y atendiendo en particular a las circunstancias del hecho insular".

78 Constitución de 1978, cit., artículo 143: “1. En el ejercicio del derecho a la autonomía reconocido en el artículo 2 de la Constitución, las provincias limítrofes con características históricas, culturales y económicas comunes, los territorios insulares y las provincias con entidad regional histórica podrán acceder a su autogobierno y constituirse en Comunidades Autónomas con arreglo a lo previsto en este Título y en los respectivos Estatutos". La entidad o "identidad" histórica queda reflejada en la denominación de la Comunidad Autónoma, según el artículo 147: “1. Dentro de los términos de la presente Constitución, los Estatutos serán la norma institucional básica de cada Comunidad Autónoma y el Estado los reconocerá y amparará como parte integrante de su ordenamiento jurídico. / 2. Los Estatutos de autonomía deberán contener: a) La denominación de la Comunidad que mejor corresponda a su identidad histórica".

79 Aunque así pretende entenderla, en la línea del segundo republicanismo, Francisco Tomás y Valiente, "Soberania y autonomia en las Constituciones de 1931 y 1978", op. cit., p. 119: "Dentro del ordenamiento jurídico del Estado, único pero complejo, el sistema político de cada Comunidad $\mathrm{y}$, en particular, sus respectivos órganos legislativos generan unos ordenamientos parciales que arrancan y tienen sus límites y sus bases en la Constitución, que han sido asumidos y completados por los respectivos Estatutos". 
sino un derecho ${ }^{80}$ de las provincias con entidad o identidad histórica ${ }^{81}$. Aunque la referencia provincial pudiera recordar a la habilitación autonómica de la Constitución de 1931, en 1978 existe un paisaje autonómico políticamente preelaborado que no localiza su germinación en el soplo de unas determinadas trayectorias de poder ascendente, sino que cuenta con la ratificación por la ciudadanía de un diseño administrativo en clave descendente. En consecuencia, la exigencia de que las provincias cumplan con tener una entidad regional histórica para aspirar a incrustarse en esa planificación autonómica es un flatus vocis o, mejor, una condición retórica que solo sirve en cuanto, por su presupuesto cumplimiento (pues toda provincia tiene entidad y toda entidad tiene historia), anticipa o explica la incorporación de los elementos provinciales al deus ex machina de la estructura autonómica82. Si solamente las provincias con entidad histórica pueden tener derecho de autonomía, pero toda provincia tiene entidad histórica, habrá que deducir no solo que todas las Comunidades Autónomas previstas serán plausibles porque no pueden haber elegido elementos inválidos (esto es, provincias sin entidad), sino también que la organización jurídica de todas las Comunidades Autónomas mediante un Estatuto de autonomía se habrá conseguido, sin un solo obstáculo, por la satisfacción del requisito inmarcesible de la historicidad. La entidad histórica no es, pues, en ninguna Comunidad Autónoma, una trayectoria cultural o política de abolengo ni una condición pendiente de verificación, sino un requisito jurídico configurador predeterminado que cualifica de antemano los elementos de una operación politico-administrativa, o sea una razón a posteriori que remite a la historia previa pero al hacerlo, con este vaivén, paradójicamente satisface en círculo vicioso la identidad desde la provincia y la provincia desde la identidad, en orden a la predestinada autonomía.

80 Una crítica del uso conceptual de este supuesto "derecho", en Antonio Torres del Moral, “¿Qué son los derechos históricos?", Ivs Fvgit, n. ${ }^{\circ} 15,2007-2008$, pp. 60-61. Ahora bien, si este derecho se identifica con el "derecho histórico" que los organismos naturales, o ahora las provincias, pueden ver reconocido, entonces obviamente la Constitución de 1978 ha provocado, con tal concepto, una reviviscencia generalizada de toda legitimación histórica que supera las opciones a las que Miguel Herrero de Miñón, "La titularidad de los derechos históricos vascos", Revista de Estudios Políticos, n. ${ }^{\circ}$ 58, 1987, p. 192, reducía - sin que se sepa cuál es la legitimidad de tal reducción, ni por qué tiene que imponerse a la vista del más amplio tenor constitucional- la presentación de la titularidad de los derechos históricos: "titulares de una foralidad política", titulares de una "foralidad civil" y "territorios donde, en el pasado, se hubieran plebiscitado Estatutos de Autonomía" (única "legitimidad democrática").

81 Aunque, como recuerda Benjamín González Alonso, "Acotaciones a la historia de la antigua corona de Castilla y a la formación de las actuales Comunidades Autónomas", op. cit., p. 92, es cierto que el artículo 11 de la Constitución de 1931 se refería a las "características históricas [...] comunes" de las provincias que pudieran organizarse en región autónoma, estas características (no identidad en sí) son una condición de una voluntad política previa que no se presume, a diferencia de lo que sucede en la Constitución de 1978, donde resulta el factor legitimador de una generalizada autonomía.

82 Para Francisco Tomás y Valiente, "Soberanía y autonomía en las Constituciones de 1931 y 1978”, op. cit., pp. 125-130, el concepto de identidad / nacionalidad histórica no ha trastornado la persistencia de la idea de superioridad normativa de la Constitución y concesión estatal (soberanía nacional) del segundo republicanismo, sino que ha generado una confusión de legitimidades ("lógica de la dualidad") entre Comunidades Autónomas, precisamente porque todas, con un mayor o menor impulso político inicial, han terminado por desarrollar la virtualidad de autogobierno habilitada por dicha legitimación. 
La constatación de que esta interpretación es correcta se encuentra en el discurrir de los acontecimientos políticos bajo la Constitución de 1978, con la precipitación de entidades que ejercen su derecho de autonomía arrogándose proliferados nuevos títulos, como identidades, nacionalidades o naciones históricas. Lo relevante no es tanto el cumplimiento presumido del requisito presupuesto constitucionalmente y cumplido naturalmente de la entidad histórica, sino el hecho de que la elaboración de fórmulas en los Estatutos de Autonomía y sus reformas haya agudizado de modo progresivo esa referencia de la historicidad identitaria, con la facilidad que concede el hecho de que la historia sea consustancial a toda comunidad y de que su calificación resulte en definitiva un acto de voluntad política con una semántica más o menos abierta, de mayores o menores límites. Este derrotero corrobora que el diseño constitucional de 1978 ofrecía a los derechos históricos la posibilidad de un marco normativo generativo (con absorción o no de una prehistoria constitucional, pues tanto vale para una digestión final estatutaria) de derechos regionales, no excluyente (ni por razón histórica, ni por razón política). La dificultad de asentar un factor objetivo esencial de diferenciación entre los derechos históricos (o de un factor objetivo politicamente validado como singular para favorecer su condición de privilegio en el seno de la igualdad constitucional) provocó la preservación política de la igualdad constitucional en el ámbito de los derechos históricos, y así ulteriormente el desarrollo todoterreno de los derechos históricos, porque todos los derechos históricos, si se trata de encontrar diferencias que los funden, son igual de diferentes, y pueden encontrar la misma o semejante razón de ser. Ahora bien, esto significa a la par que, potencialmente, el disparo intraconstitucional de los diferentes derechos históricos contra el principio constitucional (estatal) de igualdad jurídica ligado a los derechos individuales o fundamentales habria de aumentar, de modo exponencial, sus daños.

Para apreciar la metástasis de la entidad histórica constitucional provincial y volviendo a la comparación entre el modelo autonómico de 1931 y el de 1978, tal y como quedó expresado en los Estatutos de Autonomía, podemos ensayar una interpretación que parta de la construcción republicana de la autonomía intraestatal con engarce constitucional, para avanzar en contraste hacia la concepción del derecho de autonomía de las entidades históricas en un sentido más transitivo o definitivamente con potencia de desarraigo respecto del engarce constitucional 83 .

Con este patrón ${ }^{84}$ cabe la formación de dos bloques de estatutos -y reformas estatutarias por ley orgánica- de las Comunidades Autónomas (citados por su fecha de promulgación): un bloque (1) que parte del engarce constitucional y un bloque (2) proclive a la identidad histórica. Dentro de cada uno de estos bloques, en una suerte de metamorfosis, pueden incluirse las referencias conceptuales que fortalecen o alivian la primera tendencia (1.1, unidad indisoluble de la nación española; 1.2, engarce constitucional y refuerzos: unidad de la nación española y solidaridad; 1.3, mero engarce constitucional), así como

${ }^{83}$ Confirmando el "historicismo" rampante que columbró Antonio Torres del Moral, “¿Qué son los derechos históricos?", op. cit., pp. 72-74.

84 Encuentro un cuadro conceptual que apunta a los mismos conceptos estatutarios en Antonio Torres del Moral, "¿Qué son los derechos históricos?", op. cit., pp. 63-69, con un análisis constitucionalista del Estatuto de Autonomía del País Vasco y de la ley de Amejoramiento del régimen foral de Navarra. 
las que intensifican o suavizan la segunda (2.1, identidad o nacionalidad histórica, engarce constitucional y refuerzos: unidad indisoluble de la nación española y solidaridad; 2.2, identidad o nacionalidad histórica y engarce constitucional; 2.3, comunidad foral, engarce constitucional y solidaridad, derechos originarios e históricos; 2.4, nación o nacionalidad, engarce constitucional y derechos históricos), mediante matices y complementos sustantivos y calificativos. De este modo,

(1) Estatutos de Autonomía que parten del engarce constitucional.

(1.1) Unidad indisoluble de la nación española. - Madrid, $1983^{85}$.

(1.2) Engarce constitucional y refuerzos (unidad indisoluble de la nación española y solidaridad). — Melilla, $1995^{86}$.

(1.3) Mero engarce constitucional. - Asturias, 198187; Castilla-La Mancha, 1982, 199788; y Madrid, $1998^{89}$.

Como se ve, en este primer bloque la tendencia general se inclina a la declaración de un engarce constitucional sin refuerzos, de lo que se antoja paradigmática la reforma del Estatuto de la Comunidad Autónoma de Madrid.

(2) Estatutos de Autonomía proclives a la identidad histórica.

(2.1) Identidad o nacionalidad histórica, engarce constitucional y refuerzos (unidad indisoluble de la nación española ${ }^{90}$ y solidaridad). - Cataluña, identidad

${ }^{85}$ Ley Orgánica 3/1983, de 25 de febrero, BOE, 1 marzo 1983, n. ${ }^{5}$ 51, pp. 5783-5790. Artículo 1.1: "El pueblo de la provincia de Madrid, de acuerdo con la voluntad manifestada por sus legítimos representantes en el ejercicio del derecho de autogobierno, se constituye en Comunidad Autónoma en el marco del Estado español, que expresa la unidad indisoluble de la Nación Española".

${ }^{86}$ Ley Orgánica 2/1995, de 13 de marzo, BOE, 14 marzo 1995, n. ${ }^{\circ}$ 62, pp. 8061-8067. Artículo 1. : "Melilla, como parte integrante de la Nación española y dentro de su indisoluble unidad, accede a su régimen de autogobierno y goza de autonomía [...] de conformidad con la Constitución, en los términos del presente Estatuto y en el marco de la solidaridad entre todos los territorios de España".

87 Ley Orgánica 7/1981, de 30 de diciembre, de Estatuto de Autonomía para Asturias, BOE, 11 enero 1982, n. ${ }^{\circ}$ 9, pp. 524-530. Artículo 1.1: "Asturias se constituye en Comunidad Autónoma de acuerdo con la Constitución y el presente Estatuto que es su norma institucional básica".

88 Ley Orgánica 9/1982, de 10 de agosto, de Estatuto de Autonomía de Castilla-La Mancha, BOE, 16 agosto 1982, n. ${ }^{\circ}$ 195, pp. 22040-22047; artículo 1.1: "Las provincias de Albacete, Ciudad Real, Cuenca, Guadalajara y Toledo se constituyen en Comunidad Autónoma bajo el nombre de Castilla-La Mancha para acceder a su autogobierno, de conformidad con la Constitución española y con el presente Estatuto, que es su norma institucional básica”. Ley Orgánica 3/1997, de 3 de julio, BOE, n. ${ }^{\circ}$ 159, de 4 de julio de 1997, pp. 20738-20742; artículo 1.1: "Castilla-La Mancha, en el ejercicio del derecho a la autonomía reconocido constitucionalmente, accede a su autogobierno de conformidad con la Constitución Española y el presente Estatuto, que es su norma institucional básica".

${ }^{89}$ Ley Orgánica 5/1998, de 7 de julio. Artículo 1.1: "Madrid [...] en el ejercicio del derecho a la autonomía que la Constitución Española reconoce y garantiza, es una Comunidad Autónoma que organiza su autogobierno de conformidad con la Constitución Española y con el presente Estatuto, que es su norma institucional básica".

90 La unidad de España pierde el calificativo original de indisoluble en Valencia, 2006; Andalucía, 2007; y Extremadura, 2011. 
colectiva o nacionalidad (1979) 91 ; Andalucia, de identidad histórica o nacionalidad (1981) a nacionalidad histórica contemporánea (2007)92; Cantabria, de entidad o identidad regional histórica (1981) a comunidad histórica (1998) ${ }^{93}$; Murcia, entidad histórica (1982) ${ }^{94}$; Valencia, de modernización de la tradicional organización histórica del reino de Valencia (1982) a nacionalidad histórica (2006) ${ }^{95}$; Canarias, de identidad (1982) a identidad singular (1996) 96 ;

${ }^{91}$ Ley Orgánica 4/1979, de 18 de diciembre, BOE, 22 diciembre 1979, n. ${ }^{\circ} 306$, pp. 2936329370. Preámbulo: "Cataluña, ejerciendo el derecho a la autonomía que la Constitución reconoce y garantiza a las nacionalidades y regiones que integran España, manifiesta su voluntad de constituirse en comunidad autónoma. [...] El presente Estatuto es la expresión de la identidad colectiva de Cataluña y define sus instituciones y sus relaciones con el Estado en un marco de libre solidaridad con las restantes nacionalidades y regiones. Esta solidaridad es la garantía de la auténtica unidad de todos los pueblos de España". Artículo 1.1: "Cataluña, como nacionalidad y para acceder a su autogobierno, se constituye en Comunidad Autónoma de acuerdo con la Constitución y con el presente Estatuto, que es su norma institucional básica".

92 Ley Orgánica 6/1981, de 30 de diciembre, BOE, 11 enero 1982, n. ${ }^{\circ}$ 9, pp. 517-524; artículo 1.1: "Andalucía, como expresión de su identidad histórica y en el ejercicio del derecho al autogobierno que la Constitución reconoce a toda nacionalidad, se constituye en Comunidad Autónoma en el marco de la unidad indisoluble de la nación española, patria común indivisible de todos los españoles". Ley Orgánica 2/2007, de 19 de marzo, BOE, n. ${ }^{\circ}$ 68, 20 marzo 2007; preámbulo: "El ingente esfuerzo y sacrificio de innumerables generaciones de andaluces y andaluzas a lo largo de los tiempos se ha visto recompensado en la reciente etapa democrática, que es cuando Andalucía expresa con más firmeza su identidad como pueblo a través de la lucha por la autonomía plena. [...] Este ideal autonomista hunde sus raíces en nuestra historia contemporánea"; artículo 1.1: "Andalucía, como nacionalidad histórica y en el ejercicio del derecho de autogobierno que reconoce la Constitución, se constituye en Comunidad Autónoma en el marco de la unidad de la nación española y conforme al artículo 2 de la Constitución".

93 Ley Orgánica 8/1981, de 30 de diciembre, BOE, 11 enero 1982, n. ${ }^{\circ}$ 9, pp. 530-537; preámbulo: "Cantabria, como entidad regional histórica perfectamente definida dentro de España, y haciendo uso del derecho a la autonomía que la Constitución reconoce [...] manifiesta su voluntad de constituirse en Comunidad Autónoma de acuerdo con lo dispuesto en el artículo ciento cuarenta y tres de la Constitución. / El presente Estatuto es la expresión jurídica de la identidad regional de Cantabria y define sus instituciones, competencias y recursos, dentro de la indisoluble unidad de España y en el marco de la más estrecha solidaridad con las demás nacionalidades y regiones". Ley Orgánica 11/1998, de 30 de diciembre, BOE, 31 diciembre 1998, n. ${ }^{\circ}$ 313, pp. 44319-44329; preámbulo: "Cantabria, como comunidad histórica perfectamente definida dentro de España y haciendo uso del derecho a la autonomía que la Constitución reconoce [...] El presente Estatuto es la expresión jurídica de la identidad de Cantabria [...] dentro de la indisoluble unidad de España y en el marco de la más estrecha solidaridad con las demás nacionalidades y regiones".

${ }_{94}$ Ley Orgánica 4/1982, de 9 de junio, BOE, 19 junio 1982, n. ${ }^{\circ}$ 146, pp. 16756-16763. Preámbulo: "La Región de Murcia, entidad histórica perfectamente definida dentro de España, haciendo uso del derecho a la autonomía que la Constitución reconoce y en base a las decisiones de sus Ayuntamientos y del Consejo Regional Preautonómico, libre y democráticamente expresadas, manifiesta su voluntad de constituirse en Comunidad Autónoma, de acuerdo con lo dispuesto en el artículo ciento cuarenta y tres de la Constitución y con el presente Estatuto, que es su norma institucional básica. / El Estatuto es la expresión de la identidad de la Región de Murcia y define sus instituciones, competencias y recursos, con la convicción de que las Comunidades Autónomas, bajo el principio de solidaridad, contribuyen a reforzar la unidad de España".

95 Ley Orgánica 5/1982, de 1 de julio, BOE, 10 julio 1982, n. ${ }^{\circ}$ 164, pp. 18813-18820; preámbulo: "Aprobada la Constitución española, es, en su marco, donde la tradición valenciana proviniente del histórico Reino de Valencia se encuentra con la concepción moderna del País Valenciano, dando origen a la autonomía valenciana, como integradora de ambas corrientes de opinión que enmarcan lo valenciano en un concepto cultural propio en el estricto marco geográfico que comprende"; artículo 1.1: "El pueblo valenciano, históricamente organizado como 
Extremadura, identidad regional histórica (1983) por voluntad democrática de los extremeños (2011)97; Baleares, identidad popular (1983)98; Castilla y León, de identidad histórica y cultural con origen en los antiguos reinos (1983) a comunidad histórica y cultural (2007) ${ }^{99}$; y Ceuta, identidad histórica (1995) ${ }^{100}$.

Reino de Valencia, se constituye en Comunidad Autónoma, dentro de la indisoluble unidad de la nación española, como expresión de su identidad histórica y en el ejercicio del derecho de autogobierno que la Constitución reconoce a toda nacionalidad, con la denominación de Comunidad Valenciana". Ley Orgánica 1/2006, de 10 de abril, BOE, 11 abril 2006, n. ${ }^{\circ}$ 86, pp. 13934-13954; artículo 1.1: "El pueblo valenciano, históricamente organizado como Reino de Valencia, se constituye en Comunidad Autónoma, dentro de la unidad de la Nación española, como expresión de su identidad diferenciada como nacionalidad histórica y en el ejercicio del derecho de autogobierno que la Constitución reconoce a toda nacionalidad, con la denominación de Comunitat Valenciana".

${ }^{96}$ Ley Orgánica 10/1982, de 16 de agosto de 1982, BOE, 16 agosto 1982, n. ${ }^{\circ}$ 195, pp. 22047-22053; artículo $1 .^{\circ}$, párrafo primero: "Canarias, como expresión de su identidad y para acceder a su autogobierno, se constituye en Comunidad Autónoma, en el marco de la unidad de la Nación española, de conformidad con lo dispuesto en la Constitución y en el presente Estatuto, que es su norma institucional básica". Ley Orgánica 4/1996, de 30 de diciembre, BOE, 31 diciembre 1996, n. ${ }^{\circ}$ 315, pp. 38905-38912; artículo 1.1: "Canarias, como expresión de su identidad singular, y en el ejercicio del derecho al autogobierno que la Constitución reconoce a toda nacionalidad, se constituye en Comunidad Autónoma, en el marco de la unidad de la Nación española, de acuerdo con lo dispuesto en la Constitución y en el presente Estatuto, que es su norma institucional básica".

97 Ley Orgánica 1/1983, de 25 de febrero, BOE, 26 febrero 1983, n. ${ }^{\circ} 49$, pp. 5580-5586; artículo 1.1: "Extremadura, como expresión de su identidad regional histórica, dentro de la indisoluble unidad de la nación española, se constituye en Comunidad Autónoma de acuerdo con la Constitución española y con el presente Estatuto, que es su norma institucional básica”. Ley Orgánica 1/2011, de 8 de enero, BOE, 29 enero 2011, n. ${ }^{\circ}$ 25, pp. 9466-9503; artículo 1.1: "Extremadura, como expresión de su identidad regional histórica y por voluntad democrática de los extremeños, se constituye en Comunidad Autónoma, dentro de la unidad de la Nación española, de acuerdo con la Constitución y con el presente Estatuto, que es su norma institucional básica".

98 Ley Orgánica 2/1983, de 25 de febrero, BOE, 1 marzo 1983, n. ${ }^{\circ}$ 51, pp. 5776-5783. Preámbulo: "Las islas Baleares, ejerciendo el derecho a la autonomía que reconoce la Constitución española, manifiestan su voluntad de constituirse en Comunidad Autónoma, que se regulará y ordenará según este Estatuto. / En esta hora histórica en que Mallorca, Menorca, Ibiza y Formentera inician el proceso hacia la institucionalización del autogobierno, rinden homenaje a todos sus hijos que a lo largo del tiempo han trabajado para mantener la identidad de nuestro pueblo". Artículo 1..$^{\circ}$, párrafo primero: "El pueblo de las islas Baleares, como expresión de su identidad histórica y dentro de la unidad de la nación española, se constituye en Comunidad Autónoma, para acceder al autogobierno, de acuerdo con los principios y en el marco de la Constitución y del presente Estatuto, que es su norma institucional básica".

${ }^{99}$ Ley Orgánica 4/1983, de 25 de febrero, BOE, n. ${ }^{\circ}$ 52, 2 marzo 1983, pp. 5966-5972; preámbulo: "Los antiguos reinos de Castilla y León han mantenido a lo largo de los siglos una identidad histórica y cultural claramente definida dentro de la plural unidad de España. [...] La Comunidad de Castilla y León, fiel una vez más a ese pasado histórico, asume con su creación y ha de orientar los actos de todas sus instituciones a la defensa de su propia identidad, de la que constituye parte inseparable el reconocimiento y respeto a la pluralidad cultural de España, así como a una más completa solidaridad de las provincias que integran dicha Comunidad [...]"; artículo 1..$^{\circ}$ "1. Castilla y León, de acuerdo con la vinculación histórica y cultural de las provincias que la integran, se constituye en Comunidad Autónoma con arreglo a la Constitución y al presente Estatuto de Autonomía, que es su norma institucional básica. / 2. La Comunidad de Castilla y León es la institución en la que se organiza política y jurídicamente el autogobierno de la Comunidad Autónoma, asume la identidad de Castilla y León, dentro de la indisoluble unidad de España, y promueve la solidaridad entre todos los pueblos de España”. Ley Orgánica 14/2007, de 30 de noviembre, BOE, 1 diciembre 2007, n. ${ }^{\circ}$ 288; artículo 1.1: "Castilla y León es una 
(2.2) Identidad o nacionalidad histórica y engarce constitucional. - País Vasco, nacionalidad (1979)101; Galicia, nacionalidad histórica (1981)102; La Rioja, de entidad regional histórica (1982) a identidad histórica (1999)103; Aragón, de unidad e identidad histórica (1982) a identidad histórica como nacionalidad (1996) y a nacionalidad histórica (2007)104; y Canarias, identidad singular como nacionalidad $(2018)^{105}$.

comunidad histórica y cultural que tiene su origen en los antiguos Reinos de León y de Castilla, ha contribuido de modo decisivo a la formación de España como Nación, ejerce su derecho al autogobierno y se constituye en Comunidad Autónoma en el marco de la Constitución y del presente Estatuto de Autonomía".

100 Ley Orgánica 1/1995, de 13 de marzo, BOE 14 marzo 1995, n. ${ }^{\circ}$ 62, pp. 8055-8061. Preámbulo: "EI presente Estatuto de Autonomía, establecido de acuerdo con lo previsto en el artículo 144 b) de la Constitución Española, es la expresión jurídica de la identidad de la ciudad de Ceuta y define sus instituciones, competencias y recursos, dentro de la mas amplia solidaridad entre todos los pueblos de España. [...] Ceuta, consciente de su significado histórico [...]". Artículo 1. ${ }^{\circ}$ : "Ceuta, como parte integrante de la Nación española y dentro de su indisoluble unidad, accede a su régimen de autogobierno y goza de autonomía [...] de conformidad con la Constitución, en los términos del presente Estatuto y en el marco de la solidaridad entre todos los territorios de España”.

101 Ley Orgánica 3/1979, de 18 de diciembre, BOE, 22 diciembre 1979, n. ${ }^{\circ}$ 306, pp. 29357 29363. Artículo 1. ${ }^{\circ}$ : El Pueblo Vasco o Euskal-Herria, como expresión de su nacionalidad, y para acceder a su autogobierno, se constituye en Comunidad Autónoma dentro del Estado Español, bajo la denominación de Euskadi o País Vasco, de acuerdo con la Constitución y con el presente Estatuto, que es su norma institucional básica".

102 Ley Orgánica 1/1981, de 6 de abril, BOE, 28 abril 1981, n. ${ }^{\circ}$ 101, pp. 8997-9003. Artículo 1.1: "Galicia, nacionalidad histórica, se constituye en Comunidad Autónoma para acceder a su autogobierno, de conformidad con la Constitución española y con el presente Estatuto, que es su norma institucional básica".

103 Ley Orgánica 3/1982, de 9 de junio, BOE, 19 junio 1982, n. ${ }^{\circ}$ 146, pp. 16750-16756; artículo 1.1: "La Rioja, entidad regional histórica dentro del Estado español, se constituye en Comunidad Autónoma para el ejercicio de su autogobierno, de acuerdo con la Constitución y el presente Estatuto, que es su norma institucional básica". Ley Orgánica 2/1999, de 7 de enero, BOE, 8 enero 1999, n. ${ }^{\circ}$ 7, pp. 525-535; artículo 1.1: "La Rioja, como expresión de su identidad histórica y en el ejercicio del derecho al autogobierno recogido en la Constitución Española, se constituye en Comunidad Autónoma dentro del Estado Español, de acuerdo con la Constitucíon y el presente Estatuto que es su norma institucional básica".

104 Ley Orgánica 8/1982, de 10 de agosto, BOE, 16 agosto 1982, n. ${ }^{\circ}$ 195, pp. 22033-22040; artículo 1. ${ }^{\circ}$ : "Aragón, como expresión de su unidad e identidad histórica, accede a su autogobierno, de conformidad con la Constitución española y con el presente Estatuto que es su norma institucional básica". Ley Orgánica 5/1996, de 30 de diciembre. Artículo 1.1: "Aragón, en expresión de su unidad e identidad histórica como nacionalidad, en el ejercicio del derecho de autonomía que la Constitución española reconoce, accede a su autogobierno de conformidad con la Constitución y el presente Estatuto, que es su norma institucional básica". Ley Orgánica 5/2007, de 20 de abril; artículo 1.1: "Aragón, nacionalidad histórica, ejerce su autogobierno de acuerdo con el presente Estatuto, en el ejercicio del derecho a la autonomía que la Constitución reconoce y garantiza a toda nacionalidad".

105 Ley Orgánica 1/2018, de 5 de noviembre, BOE, 6 noviembre 2018, pp. 107645-107708. Artículo $1 .^{\circ}$ : "1. Canarias es un archipiélago atlántico que, como expresión de su identidad singular basada en sus circunstancias geográficas, históricas y culturales, ejerce el derecho al autogobierno como nacionalidad, constituyéndose en Comunidad Autónoma en el marco del Estado español. [...] 2. El autogobierno del pueblo canario se funda en la Constitución [...]”. 
(2.3) Comunidad foral, engarce constitucional y solidaridad, derechos originarios e históricos: - Navarra, 1982106.

(2.4) Nación o nacionalidad, engarce constitucional y derechos históricos: Cataluña, nación o nacionalidad histórica (2006) ${ }^{107}$; y Aragón, nación o nacionalidad histórica de naturaleza foral (2018) ${ }^{108}$ pero sin la forma de ley orgánica y declarada inconstitucional ${ }^{109}$.

106 Ley Orgánica 13/1982, de 10 de agosto, BOE, 16 agosto 1982, n. ${ }^{\circ}$ 195, pp. 22054-22060. Artículo 1. ${ }^{\circ}$ : "Navarra constituye una Comunidad Foral con régimen, autonomía e instituciones propias, indivisible, integrada en la Nación española y solidaria con todos sus pueblos". Artículo 2. ${ }^{\circ}$ : "Los derechos originarios e históricos de la Comunidad Foral de Navarra serán respetados y amparados por los poderes públicos con arreglo a la Ley de veinticinco de octubre de mil ochocientos treinta y nueve, a la Ley Paccionada de dieciséis de agosto de mil ochocientos cuarenta y uno y disposiciones complementarias, a la presente Ley Orgánica y a la Constitución, de conformidad con lo previsto en su disposición adicional primera".

107 Ley Orgánica 6/2006, de 19 de julio, BOE, 20 julio 2006, n. ${ }^{\circ}$ 172. Preámbulo: "El pueblo de Cataluña ha mantenido a lo largo de los siglos una vocación constante de autogobierno, encarnada en instituciones propias como la Generalitat - que fue creada en 1359 en las Cortes de Cervera- y en un ordenamiento jurídico específico recogido, entre otras recopilaciones de normas, en las 'Constitucions i altres drets de Catalunya'. [...] historia que los hombres y mujeres de Cataluña quieren proseguir con el fin de hacer posible la construcción de una sociedad democrática y avanzada, de bienestar y progreso, solidaria con el conjunto de España e incardinada en Europa. [...] El autogobierno de Cataluña se fundamenta en la Constitución, así como en los derechos históricos del pueblo catalán que, en el marco de aquélla, dan origen en este Estatuto al reconocimiento de una posición singular de la Generalitat. [...] El Parlamento de Cataluña, recogiendo el sentimiento y la voluntad de la ciudadanía de Cataluña, ha definido de forma ampliamente mayoritaria a Cataluña como nación". Artículo 1. : "Cataluña, como nacionalidad, ejerce su autogobierno constituida en Comunidad Autónoma de acuerdo con la Constitución y con el presente Estatuto, que es su norma institucional básica”.

108 Ley 8/2018 de 28 de junio "de actualización de los derechos históricos de Aragón", BOE, 29 agosto 2018, n. ${ }^{\circ}$ 209, pp. 85400-85413. Preámbulo: "Aragón es una nacionalidad con más de doce siglos de historia. [...] Sobre este amplio y variado territorio, sucesivas generaciones de aragoneses y aragonesas fueron construyendo una nación fundada en la defensa de sus libertades, dotada de instituciones singulares [...]". Artículo $1 .^{\circ}$ : "1. Aragón es una nacionalidad histórica, de naturaleza foral, cuya identidad jurídica, así como la voluntad colectiva de su pueblo de querer ser, se han mantenido de manera ininterrumpida desde su nacimiento. / 2. La participación de Aragón en el proceso histórico de construcción de España no ha supuesto la renuncia a sus derechos históricos. Su actualización es legítima de acuerdo con la disposición adicional primera de la Constitución y según se prevé en la disposición adicional tercera del Estatuto de Autonomía de Aragón".

109 Por la sentencia del Tribunal Constitucional 2018/5212, con los motivos de infracción de la jerarquía normativa constitucional y en concreto de la disposición adicional primera que limita a Navarra y el País Vasco el reconocimiento de la foralidad y los derechos históricos, la vulneración de la soberanía nacional y de la configuración constitucional (que ha de imponerse a la legitimación de los derechos históricos) del Estado autonómico, más la infracción constitucional que supone la "condición política de aragonés y natural de Aragón", entre otras consideraciones, pero sin defender la competencia exclusiva estatal (art. 149.1.1. ${ }^{\circ}$ de la Constitución de 1978: la "regulación de las condiciones básicas" debe excluir nuevas formulaciones y catalogaciones autonómicas) respecto de los derechos fundamentales y libertades públicas, antes bien admitiendo la regulación legislativa autonómica, salvo el reproche de su legitimación histórica, y estableciendo, con algún precedente jurisprudencial constitucional, de forma increíble, dos tipos de derechos: "los derechos fundamentales que la Constitución proclama y los derechos reconocidos en los Estatutos de Autonomía son cosa distinta, pues los primeros son fundamentales como consecuencia de su consagración por la Constitución y, consecuentemente, vinculan a todos los poderes públicos, tanto estatales como autonómicos, mientras que los derechos reconocidos en los Estatutos de Autonomía, que están materialmente conectados con el 
Como ha podido comprobarse, en este segundo bloque las reformas estatutarias tienden a intensificar la cualidad de la historicidad, de la identidad o entidad hacia la nacionalidad, y de la nacionalidad hacia la nación. Aunque el engarce constitucional siempre esté presente (no así sus refuerzos), son los derechos históricos los que más presionan en el sentido de su relajación. Desde este punto de vista la solución más equilibrada (o equilibrista) es la de la Comunidad Autónoma de Navarra, porque la definición como comunidad foral evita la pulsión historicista hiperbólica identitaria de la nacionalidad o la nación en cuanto pueda ser contraria a la "integración y solidaridad" en España, aunque al mismo tiempo preserva su matiz histórico, que se refuerza en la naturaleza original de sus derechos históricos: si esta originalidad se antoja en principio evocadora de la naturalidad preconstitucional, parece al mismo tiempo, por su foralidad, o localismo constitucionalizado, extrañamente menos agresiva. Al menos, de agresividad menor a la arrogación de derechos históricos desde una nación paralela a la española, como en la ambigua (nación preambular y nacionalidad dispositiva) última reforma catalana, y en la inconstitucional aragonesa (donde además la "naturaleza foral", a la manera navarra, se predica empero de la nacionalidad). Las Comunidades Autónomas de Cataluña y Aragón son precisamente las que saltan en sus reformas de un apartado catalogador a otro, en la evolución general hacia una mayor densidad conceptual en la expresión del historicismo.

La inconstitucional "actualización de derechos históricos" en la Comunidad Autónoma de Aragón es particularmente relevante porque permitirá situar en la doctrina del Tribunal Constitucional el límite de la inflación historicista, y verificar cómo se motiva y hasta qué punto se determina con criterios de igualdad. Dejaremos esta cuestión a los constitucionalistas, porque ahora lo interesante es hacer notar cómo, al expresarse la ley autonómica sin pelos en la lengua, trasluce hasta qué punto ha podido considerar el legislador autónomico viables constitucionalmente sus pretensiones. Para empezar, la ley, con simulada moderación, no reconoce derechos históricos, sino que acomete su "actualización"110; pero como la "actualización" no procede exclusivamente de la formulación de un derecho nuevo en el ámbito del gobierno autonómico, sino que supone, al menos ideológicamente, la prolongación o reviviscencia de una actividad jurídica preexistente ${ }^{111}$, queda sinuosamente proclamada una

ámbito competencial propio de cada Comunidad Autónoma, sólo vinculan a los poderes públicos de esta última”. Esta concepción que parece presumirse abstracta de los derechos, porque prescinde de su concreción institucional o de las desigualdades que al concretarse institucionalmente generen entre autonomías, corre el riesgo de convertir el derecho autónomico en derecho internacional privado.

110 Dificil tiene que ser la actualización de una foralidad cuando, como afirma Tomás Ramón Fernández, Los derechos históricos de los territorios forales. Bases constitucionales y estatutarias de la administración foral vasca, Civitas-Centro de Estudios Constitucionales, Madrid, 1985, p. 45, "los Fueros no son ni han sido nunca un cuerpo de normas fijo e inmutable", porque entonces la actualización es congénita y no ha podido haber en puridad fueros originarios consolidados.

111 Lo reconoce la propia ley 8/2018 de 28 de junio "de actualización de los derechos históricos de Aragón", cit., preámbulo: "El objetivo de una ley de actualización de los derechos históricos es tratar de afirmar y proteger la identidad aragonesa. Actualización significa decantar la esencia regulatoria de esa identidad constitucional histórica de Aragón, eliminando cualquier reminiscencia de un régimen señorial incompatible con nuestro actual sistema constitucional democrático. También es adaptación de esa raíz regulatoria a un nuevo entorno social, receptivo y abierto a otras culturas, religiones y etnias que vuelven a un territorio que en el pasado también 
legitimación que hurta el cuerpo al ámbito constitucional. A este planteamiento le acompaña, en el preámbulo de la ley, la recreación de la historia misma en la que nacen y beben los derechos históricos. Se compone entonces un relato de historia-ficción (inusitado en la retórica de las entidades, identidades, nacionalidades o naciones históricas, salvo quizá en la última reforma estatutaria catalana) que ofrece, por una parte, la historia jurídica politico-administrativa ${ }^{112}$, de la que por lo menos habrá que advertir su alto grado de tergiversación ${ }^{113}$, y por otra parte el recordatorio de un ordenamiento foral o sistema jurídico histórico ${ }^{114}$ volcado exageradamente en una interpretación ideológica de aliento

fue receptor. Aragón, mediante la presente ley, proclama su condición de territorio foral por legitimidad histórica y porque lo dispone su Estatuto de Autonomía, según el cual, los derechos históricos de Aragón podrán ser actualizados de acuerdo con lo que establece la disposición adicional primera de la Constitución española”.

112 Valgan las siguientes perlas de la ley 8/2018 de 28 de junio "de actualización de los derechos históricos de Aragón", cit., preámbulo: "Aragón es una nacionalidad con más de doce siglos de historia. [...] Sobre este amplio y variado territorio, sucesivas generaciones de aragoneses $\mathrm{y}$ aragonesas fueron construyendo una nación fundada en la defensa de sus libertades, dotada de instituciones singulares (Rey, el Príncipe de Gerona, Cortes, Justicia Mayor, Diputación del Reino, Maestre Racional, los Municipios y Comunidades) y depositaria de un rico patrimonio natural, cultural, jurídico y lingüístico. Un país que fue germen y cabeza de una confederación peculiar y precursora en Europa: la Corona de Aragón. / Las Cortes creadas en el siglo XII eran consideradas por los aragoneses como las representantes del Reino [...] Sus principales funciones eran la de resolver los agravios, acordar la politica interior y exterior del Reino y decidir la legislación y los tributos. Asimismo, servian de medio para financiar las empresas reales, a cambio de la concesión de privilegios a los súbditos. Por otra parte, es necesario destacar que pese a la supresión de las instituciones aragonesas por los Decretos de Nueva Planta, en Aragón seguía presente la conciencia de Reino, lo que permite explicar que las Cortes de Aragón fueran las únicas de toda la Corona de Aragón que se reunieran más de un siglo después de la celebración de las anteriores, concretamente el 9 de junio de 1808, convocadas por el Capitán General de Aragón, José de Palafox, durante los Sitios de Zaragoza. [...] El Justicia de Aragón es el símbolo de la cultura jurídico-politica aragonesa y su imagen reconocible en la doctrina y la práctica constitucional de otros países de Europa y América. Invocando el uso de una jurisdicción propia del Reino, ha podido someter a control judicial las actuaciones del Rey y sus Oficiales y cualesquiera otras instituciones de administración y gobierno; en un contexto de Antiguo Régimen dominado por la arbitrariedad, la actividad del Justicia de Aragón permitió articular un sistema con potestades más regladas y actuaciones sometidas a control y responsabilidad".

113 Así, por ejemplo, se ignora el concepto histórico medieval y moderno de nación, así como el significado de la voz "libertad" (privilegio, exención, franquicia), se confunde el arbitrio judicial con la arbitrariedad, y se desconoce la verdadera naturaleza y funcionamiento de las Cortes. La repetición de disparates excusa de un examen detenido; por lo demás, son cuestiones suficientemente bien conocidas que puede aclarar cualquier historiografia no rocambolesca. En cuanto a la naturaleza de las Cortes, a propósito del simulacro de las convocadas por Palafox, puede leerse a Antonio Peiró Arroyo, Las Cortes aragonesas de 1808. Pervivencias forales y revolución popular, Cortes de Aragón, Zaragoza, 1985, pp. 97-101. En fin, las referencias al Justicia Mayor tergiversan ciertas competencias obviando su naturaleza de oficio regio, así como su compleja inhibición y declinación respecto de la jurisdicción regia común: cf. José Antonio López Nevot, "La exigencia de responsabilidad del Justicia de Aragón en proceso de 'enquesta”, en Ignacio Czeguhn, José Antonio López Nevot, Antonio Sánchez Aranda (eds.), Control of Supreme Courts in Early Modern Europe, Duncker \& Humblot, Berlin, 2018, pp. 297-324.

114 Ley 8/2018 de 28 de junio "de actualización de los derechos históricos de Aragón”, cit., preámbulo: "El Derecho Foral aragonés ha sido el elemento principal de la formación, permanencia y continuidad de la identidad aragonesa hasta nuestros dias. [...] Desde la inicial apertura a la aplicación analógica de los textos — previendo el recurso a la 'igualeza', en virtud de la cual los asuntos semejantes deben tener soluciones semejantes - hasta la lectura que finalmente se dio del Standum est Chartae como principio hermenéutico de la que se hizo derivar la aplicación literal de las normas. [...] La esencia del antiguo Reino de Aragón eran sus Fueros, 
pactista ignorante tanto del significado de este último cuanto de la técnica histórica característica de todo ius proprium ${ }^{115}$.

Desde un punto de vista conceptual podría recordarse también la fantasmagoría de la Comunidad Autónoma de Extremadura, que si aparentemente cambia poco su definición al añadir la referencia a la voluntad democrática de los extremeños, permite atisbar una alusión suave y difusa a una especie de extremeña parasoberanía, o sea, en vez de una sencilla habilitación de expresión autonómica en virtud del procedimiento constitucional, una insinuada invocación a la soberanía originaria del pueblo regional.

que emanaban de una concepción pactista del poder: no era Fuero la voluntad del Rey, sino su acuerdo con los cuatro Brazos de las Cortes. El principio esencial del sistema constitucional histórico de Aragón es la supremacía del Derecho. [...] Dentro de los límites de una sociedad de Antiguo Régimen, en Aragón había una preocupación demostrable por prohibir o reducir la arbitrariedad. Y el pueblo aragonés siempre se caracterizó por defender celosamente sus Fueros y Libertades, hasta el punto de que el Justicia Mayor Juan de Lanuza el Mozo fue decapitado, tras la rebelión de 1591, por encabezar su defensa. / A principios del siglo XVIII, los llamados Decretos de Nueva Planta abolieron, por derecho de conquista, el Derecho público y las instituciones propias del Reino de Aragón, que había sido Estado independiente durante setecientos años. Los aragoneses únicamente pudimos conservar el Derecho privado plasmado en el Cuerpo de Fueros, Observancias y Actos de Corte del Reino de Aragón, que, a través del Apéndice de 1925, la Compilación de 1967 y, una vez recuperado el autogobierno, diversas leyes autonómicas hoy refundidas en el Código del Derecho Foral de Aragón, ha subsistido hasta nuestros dias".

115 No hay singularidad en la tradición foral aragonesa respecto de otras tradiciones forales o estatutarias europeas, ni siquiera en las formas de suplir (verbigracia, la analogía, la equidad, el sentido o la razón natural) los fueros locales y el ius regium de carácter general. Tampoco la hay en el principio standum est chartae. Pero desde luego el pactismo no significó que los fueros no reflejaran técnicamente la voluntad del rey sino un "acuerdo" del rey con los brazos de Cortes, porque estos brazos eran convocados por el rey para la obtención de consejo y desde luego el fuero resulta aprobado por el rey no con las Cortes sino en las Cortes, al margen de la evidente facultad del rey para legislar motu proprio; la atribución de una eficacia pactista de los fueros aprobados en Cortes, en el sentido de la irrevocabilidad por parte del rey sin la activación del consejo de Cortes, aun aceptada eventualmente por el rey, no es sino un discurso ideológico de parte (estamental) que pretende contrapesar particularmente la obtención regia de donativos económicos y apuntalar sus victorias materiales normativas; y en definitiva, no es sino el régimen de la irrevocabilidad, que admite la excepción por causa de utilidad pública, típica del privilegio. Arbitro y fuero no son dos conceptos opuestos: arbitro en rigor es el ejercicio del ministerio de la ley, y el fuero es la ley singular, esto es, el privilegio, local o estamental. La alusión al derecho de conquista como fundamento de la derogación parcial del Derecho aragonés por los Decretos de Nueva Planta (1707 y 1711) guarda silencio sobre el origen de ese derecho, esto es, sobre la comisión de crímenes de sedición y traición al romper el juramento previo de fidelidad al rey (por el que se conseguía a su vez precisamente el reciproco compromiso de respeto a los fueros); curiosamente, la ley acepta el "testimonio", la "identidad colectiva" del derecho privado aragonés, cuando esta singularidad reconocida por el rey estuvo apoyada en la congelación, suprimidas las Cortes, del ius proprium, a modo de permisión de una excrecencia rígida cuya imposibilidad de renovación dejaba paso libre al derecho castellano. Por lo demás, a efectos constitucionales, se yuxtaponen en la ley autonómica aragonesa dos legitimaciones del gobierno autonómico: el Estatuto (constitucionalmente, pero sin referencia a la Constitución más que en su reconocimiento de los derechos históricos) y la legitimidad histórica (como hemos visto, previamente falseada). 


\section{CRÍTICA DE LA DOCTRINA JURÍDICA DE LOS DERECHOS HISTÓRICOS.}

La multiplicación de las identidades, nacionalidades y naciones históricas bajo la Constitución de 1978 permite la valoración de una doctrina jurídica que a propósito de los derechos históricos se ha movido entre la filosofia jurídica y la interpretación técnica constitucional, con el telón de fondo más o menos atendido de las razones históricas.

A menudo la interpretación de los "derechos históricos" ha discurrido teñida de fatalismo, como si la cuestión radical a resolver fuera su existencia o no, o su historicidad, y como si su existencia histórica derivase, al ser confirmada, en una solución constitucional forzada por su entidad. Por otra parte, en la cuestión se mezclan sin rubor perspectivas disimiles: el discurso ideológico y el discurso jurídico, históricos o actuales. Se olvida que no toda ideología tiene una traducción jurídica, ni es fatal la conclusión de que la tenga por mucho que la ideología persista; una vez que la consigue, otro asunto, todavía distinto, será cuál deba proponerse como la interpretación jurídica cabal de su reconocimiento, lo que varía según su posición preeminente o bien condicionada por otros parámetros ideológicos o técnicos. Así, la argumentación pactista que aplica a la ley la naturaleza de contrato es una ideología que perdura durante el vigor de una teoría jurídica que en rigor nunca acepta una identificación técnica de tal jaez; respecto de los derechos forales, el hecho de que el foralismo consiguiese retardar una codificación civil común sustantivamente necesaria desde el punto de vista constitucional es un dato histórico y politico, pero que no tiene que ver con la naturaleza de los derechos forales, que podrian haber sido radicalmente sometidos a aquella razón común al socaire del principio de igualdad y de unidad de código. Esto es, las decisiones políticas históricas no están predefinidas en la naturaleza de los objetos, al menos no exclusivamente.

Por lo demás, la interpretación jurídica posterior a la resistencia de los derechos históricos y a su exitoso paso de la ideología al sistema jurídico, si se produce, seguirá coexistiendo, indudablemente, con otros ciertos principios jurídicos que tampoco han sido demolidos pese a sus propios obstáculos: el problema del reconocimiento en la Constitución de 1978 de los derechos históricos — tras las páginas anteriores puede ya decirse- no es su existencia o no, su existencia real o ficticia, ni está zanjado simplemente por su constitucionalización, sino que responde a la congruencia que pueda tener en la trayectoria de una determinada constitución del Estado con una determinada axiología jurídica de origen individual e igualitario. Si la torturada historia constitucional de los derechos individuales remite a la construcción de un sistema jurídico en el que se acepta como indiscutible, aun desde las perspectivas garantistas o limitadoras más diversas, el principio de igualdad jurídica, los derechos históricos, de proposición advenida, tienen que merecer un juicio de oportunidad, relacionado con su homogeneidad respecto de tal criterio o con el desajuste que puedan provocar, tal y como el reconocimiento de los derechos sociales, o la legalización de los derechos individuales, y aun los derechos nacionales estatales, pudieron poner en tela de juicio la naturaleza de los derechos individuales postulados, de forma constante, como fundamento del sistema jurídico. Prescindir de este contexto con el afán de promover un reconocimiento determinado de los derechos históricos o de defender una determinada interpretación de su encaje constitucional no parece un camino coherente con una existencia o historia previa, porque la arrogancia existencial 
de los derechos históricos pueden reivindicarla, y con razón más temprana en la construcción del Estado de Derecho, los propios derechos individuales potencialmente afectados. De modo que si se aboga por la delimitación de estos en función de aquellos habrá que hacerlo al menos de manera palmaria y reconociendo que se trata de una interpretación ideológica que interesa una quiebra en la historia misma planteada inicialmente del trayecto constitucional.

La concepción existencial de los derechos históricos ha sido esgrimida por Miguel Herrero de Miñón con ciertas variantes. El punto de partida de su razonamiento no es, en realidad, una existencia, sino una esencia: la que obtienen los derechos históricos con su constitucionalización, en la disposición adicional primera ${ }^{116}$ de la Constitución de $1978^{117}$. Los derechos históricos existen y lo cierto es que la Constitución los ha reconocido, y esta idea parece ser una forma precavida de evitar la acusación de una comprensión de los derechos históricos contraria al proceso politico constitucional: su historia previa interesa solo a los efectos de constatar que fueron, pero no cómo fueron (no vaya a descubrirse algún parámetro interno de inconstitucionalidad, como el trasfondo de la desigualdad o el privilegio como aspiración).

Rápidamente la precaución demuestra su cartón piedra, porque la existencia histórica es necesaria para sostener no que la Constitución pudo reconocer o no en virtud de su propia axiologia, sino que la Constitución tuvo que reconocer, sin remedio, esos derechos históricos que remitian a "hechos diferenciables irreductibles a una común pauta, ya centralizada, ya autónomica"118. Esto es algo, según Herrero de Miñón, que "nadie discute", cuando lo que en verdad "nadie discute" es que la decisión politica constitucional fuera esta, y no que no hubiera podido ser otra. La prueba de que Herrero de Miñón sigue necesitando la historia, más allá de la Constitución, reside en que inmediatamente recurre a una perfecta combinatoria de historicidad y constitucionalidad: la "constitución tradicional o histórica", por cierto el mismo concepto que obstaculizó el principio de igualdad y los derechos individuales en la historia constitucional. Esta constitución histórica facilita, sea históricamente verdadera o falsa, detectar una "identidad nacional", y es el mismo concepto con el que se hace posible situar a los derechos históricos no al margen sino en el seno de la constitucionalización ${ }^{119}$ : un limite aceptado por Herrero de Miñón al describir la fuerza de los derechos históricos (necesario para el contraste de su

116 Constitución de 1978, cit., disposición adicional 1. a: "La Constitución ampara y respeta los derechos históricos de los territorios forales. / La actualización general de dicho régimen foral se llevará a cabo, en su caso, en el marco de la Constitución y de los Estatutos de Autonomía”.

117 Miguel Herrero de Miñón, Idea de los derechos históricos, Espasa Calpe, Madrid, 1991, p. 15: "La meta a alcanzar en este libro es la 'idea' de un objeto que viene dado por la vigente Constitución española en su Disposición Adicional 1. ${ }^{a}[\ldots]$ ”.

118 Miguel Herrero de Miñón, Idea de los derechos históricos, op. cit., pp. 26-27: "Porque nadie discute que la Adicional $1 .^{a}$ fue introducida por el constituyente con el fin de resolver el problema que, a la convivencia democrática y a la identidad de los españoles todos, planteaban la existencia de hechos diferenciables irreductibles a una común pauta, ya centralizada, ya autonómica”.

119 Miguel Herrero de Miñón, Idea de los derechos históricos, op. cit., pp. 48-49 y 54: “"Los Derechos Históricos significan la posición de las comunidades histórico-políticas, un concepto clave [...] que aúna las ideas de autonomía y de integración; es decir, de afirmación de la propia personalidad y de articulación con un conjunto global”. 
singularidad) que, finalmente, será abandonado para no aceptar límite alguno ${ }^{120}$, lo que cuando menos demuestra su artificiosidad, su puro valor ideológico pero de ninguna manera técnico, porque la viabilidad de la constitución histórica se explica no porque esta noción tenga una entidad técnica separada de la constitución normativa, sino tan solo en la medida en la que influye en las instituciones recogidas en esta última ${ }^{121}$.

Una vez localizada la "identidad nacional" que reclamará su constitucionalización, Herrero de Miñón, de acuerdo con la evanescente constitución histórica, se despreocupa de las "novaciones" (objetiva o subjetiva) del "ser" al que la identidad se refiere: los fueros o los derechos históricos pueden haber cambiado a lo largo de la historia, como pueden haber cambiado "los titulares de los derechos históricos". La terminología jurídica se convierte, con su alegre volubilidad, en pastiche, así empleada con una función de disfraz del "mito", de acuerdo con Javier Corcuera 122. Ahora se comprende que la constitucionalización sea raíz necesaria, porque, como si de la teoría de las cuerdas se tratase, aquella puede fijar una realidad (al menos, actual) de entre las proyecciones posibles simultáneas de los derechos históricos. Pero Herrero de Miñón evita todavía este uso de la Constitución, tan alambicado. Para ello, sabe que debe precisar una esencia de la identidad frente a aquella complejidad novativa, y lo hace señalando que la "infungibilidad de un hecho diferencial" es la sustancia decantada: por fin una definición de la identidad que permite confirmar cómo los derechos históricos "no son una creación de la Constitución" porque tienen un "ser" fuera de ella. Los derechos históricos son, pues, un apriorismo "pre y para normativo, pre y para constitucional". Es entonces, al llegar a esta conclusión, cuando la Constitución presta su servicio, porque con su amparo de los derechos históricos reconoce dicha existencia preconstitucional. Y la consecuencia de este orden es importante: los derechos históricos no pueden ser

120 Miguel Herrero de Miñón, Idea de los derechos históricos, op. cit., p. 120: "La realidad obliga a reconocer que la supuesta voluntad constituyente incondicionada y unitaria no existe politicamente y en consecuencia no puede tener relieve jurídico alguno".

121 Aunque suelen contraponerse, constitución histórica y constitución normativa no son nociones alternativas, porque lo que se discute con la primera es la plena asunción o no de determinadas concepciones técnicas liberales (soberanía nacional, sufragio universal, aconfesionalidad, etc.), mientras que la segunda se refiere a la supralegalidad del texto constitucional (que puede plantearse tanto respecto de una constitución historicista cuanto respecto de una constitución plenamente innovativa).

122 Javier Corcuera Atienza, "La constitucionalización de los derechos históricos. Fueros y autonomía", Revista Española de Derecho Constitucional, n. ${ }^{\circ}$ 11, 1984, p. 13: "Ello permite identificar 'derechos históricos' con 'fueros' y referirse a éstos como si se estuviera hablando de un ordenamiento histórico concreto, o hablar de las defensas del fuero planteadas desde el siglo XVI como si desde entonces hasta hoy se reivindicara lo mismo y por las mismas razones. El fuero deja de ser historia y se convierte en naturaleza, en expresión de 'la vasquidad' (de una 'vasquidad' definida desde la coyuntura política y, evidentemente, por aquel que tiene capacidad de imponer su definición de la misma). / Tal transformación de la historia en naturaleza, tal secuestro de la historia, se hace, evidentemente, en nombre de la historia: la multiplicación de ejemplos sacados de ella en que lo único común es la utilización de semejantes afirmaciones de amor a los fueros, permite obviar el estudio de lo que en cada momento se entiende como fueros, de lo que en cada momento se reivindica (y de quién, cómo y por qué lo reivindica) para resumir que, desde siempre, 'vasquismo' ha sido 'fuerismo"'. 
definidos por la Constitución, porque ya lo están, y tienen "inmunidad" ante la revisión constitucional ${ }^{123}$.

A pesar de lo inteligente, por geométrica, que parece la argumentación, su fundamento es muy endeble ${ }^{124}$. La idea de que, al reconocer, la Constitución confirma la identidad preexistente a la que responden los derechos históricos, no tiene nada de particular ni implica que la Constitución haya absorbido fatalmente ese limite contra su propia axiología de los derechos. Puede comprobarse la utilización del término de "reconocimiento" durante la II República, en la teoría autonómica, con la advertencia de que en todo caso el autogobierno respondía a una concesión estatal. Hay en todo esto un cierto juego de prestidigitación con el lenguaje: ¿qué otra cosa puede decir la Constitución, dispuesta a aceptar los derechos históricos, sino que los reconoce? ${ }^{125}$ ¿Qué cosa jurídica o no jurídica

${ }_{123}$ Miguel Herrero de Miñón, Idea de los derechos históricos, op. cit., pp. 61, 66, 69, 73, 77, 80-82.

124 Dice en uno de sus últimos escritos Miguel Herrero de Miñón, "Derechos históricos", Iura Vasconiae, n. ${ }^{\circ} 16,2019$, que, respecto de la "comunidad política" vasca (al referir los requisitos siguientes, se evita deliberadamente el término de nación, en p. 577), p. 580: "El territorio es indispensable e indiscutible, pero aparece fraccionado y siempre incompleto; la lengua propia es, a la vez, minoritaria; el derecho aun en vías de recuperación, trasformación y asentamiento. Y, pese a tamaña fragilidad todos ellos aparecen nimbrados de un plus de significado, de un superávit de sentido. El territorio supera su fraccionamiento, irurak bat; la lengua se hace 'propia' entre quienes la desconocen; y el derecho civil se territorializa". Este superávit está fundamentado en una manifestación popular espontánea (se consigue así que parezca brotada del terruño antes que postulada por una concreta ideología nacionalista) que remite a Savigny (p. 582) y que da pie a legitimar (p. 583) la categoría de "'normas superpuestas', ajenas a la Constitución, a las que la Constitución se remite pero que ni el propio constituyente puede derogar, porque tampoco las creó". Cabe preguntarse quién las creó, entonces. ¿Cómo es posible la acción de un espíritu popular a partir de un territorio incompleto, una lengua minoritaria y un derecho cuya foralidad carece históricamente de fundamento originario? No lo explica Herrero de Miñón, que simplemente cree que esa transfiguración, como si se tratara de una aparición mariana, se ha producido indiscutiblemente. Es decir, el espíritu popular de su Palmar de Troya no ha tenido un territorio incompleto, sino un territorio incompleto en superávit; no ha tenido una lengua minoritaria, sino una lengua minoritaria con pulsión de mayoria, y no ha tenido una foralidad como cualquier otra y aun tardía, sino superboyante y constitucionalizante. Ni siquiera se admite un rigor histórico de fases o periodos, tan legitimantes unos como otros en cuanto anclados en unos $\mathrm{u}$ otros hechos. El superávit asienta su trono en el cielo y desde allí juzga globalmente la historia y su trance completo. Por supuesto que, como su constatación es artificial, hay que atribuírsela al pueblo, para salvar la fachada democrática, un pueblo que nadie sabe lo que es ni lo que ha sido en cuanto dador de superávits, pero que desde luego no es el conjunto de los individuos que no han dotado de superávit al déficit, lo que demuestra el sentido profundamente reaccionario de la teoría, y que en definitiva quien crea el superávit es un ídolo, un ídolo con muchas caras, un ídolo de ideólogos que con su varita mágica convierten el territorio en suficiente, la lengua minoritaria en reconocida (en cuanto tarde en imponerse artificialmente), y el derecho en una singularidad ficticia. Entre otras varitas mágicas, una pertenece como ídolo de infantería al propio teórico, que compone desde el artificio y hacia atrás su especulación, a partir de sus premisas sumando al deus ex machina el anacronismo. En definitiva, un típico pensamiento elitista y oligárquico, tanto mejor maquillado cuanto pretendidamente al servicio de un espíritu popular (a la postre, claro, selecto). Y si no, recuérdese la desactivación política (de responsabilidad no exclusivamente nacionalista) de algún verdadero y hastiado espíritu popular, como el de julio de 1997 en Ermua.

125 Cuando Miguel Herrero de Miñón, "Los derechos históricos y el principio pacticio", Ivs Fvgit, n. ${ }^{\circ} 15,2007-2008$, pp. 37-38, afirma que "solo a lo que ya existe se respeta y ampara [...] o lo que es lo mismo lo que se respeta y se ampara no se crea, sino que se da ya por existente", refiriéndose a "los Derechos Históricos, de cuyo respeto y amparo se deduce su 'pre' y 'paraconstitucionalidad'. Son, en este sentido, originarios [...] Remiten a la historicidad de unos 
puede no existir hasta el instante mismo en que la Constitución la nombra? ¿No tendrá que existir previamente el concepto que sirve a lo que la Constitución dispone? Parece que esto es así, incluso en la mayor innovación institucional constitucional. De modo que nadie discute preexistencias de entidades; lo que se discute es si la fuerza jurídica de lo existente (lo conocido y reconocido) en la Constitución procede de la propia Constitución o está al margen de la Constitución. Este es el busilis, quizá fácil de resolver en la evanescencia de una constitución histórica, pero nada claro, preexistan identidades o no, en el seno de una Constitución con fuerza normativa ${ }^{126}$.

Cuando Herrero de Miñón fundamenta los derechos históricos más allá de la Constitución, imagina una paraconstitución ${ }^{127}$, fruto del despiece, contra toda lógica jurídica, de la normativa del redondo texto constitucional. Al aceptar una pluralidad de paraconstituciones (en la medida en la que acepta derechos históricos de varias comunidades históricas), reconoce que ese "conjunto global" de residencia encontrado en la constitución histórica, donde asumir los derechos históricos, no es cierto. Es verdad que, si los derechos históricos tienen fuente originaria propia al margen de la Constitución, se ha soslayado la dificultad de la ruptura del principio constitucional de igualdad jurídica, pero a la sazón quedarán disgregadas las titularidades de los derechos históricos, en un ficticio o virtual magma global.

Por otra parte, el reconocimiento de "inmunidad" a los derechos históricos ante la reforma constitucional es evidentemente anticonstitucional ${ }^{128}$; y si lo es

hechos: la existencia de un cuerpo politico singular, esto es, diferente e infungible", parece derivar de este carácter una constitucionalidad fatal, ineluctable, sobre cuya razón hay que recordar que, por mucho que los derechos históricos se reivindicaran preexistentes, y que su evolución como derechos forales fuera externa a la constitucional (como explica Bartolomé Clavero, El código y el fuero. De la cuestión regional en la España contemporánea, Siglo Veintiuno Editores, Madrid, 1982 , pp. 22-23), en definitiva de lo que se trata (como respecto de tantos factores retrógrados, los ampare la Constitución o no) es de si resultan coherentes con los principios constitucionales, en particular de igualdad jurídica, de modo que, entonces, si salvan la antinomia no será por su preexistencia, sino precisamente por su constitucionalización.

126 Una crítica de la supraconstitucionalidad de los derechos históricos, en Eduardo Nieto Arizmendiarrieta, "Reflexiones sobre el concepto de derechos históricos", op. cit., pp. 150-154.

127 Cf. Javier Corcuera Atienza, "Notas sobre el debate de los derechos históricos de los territorios forales”, en Revista de Estudios Políticos, n. ${ }^{\circ} 46-47,1985$, pp. 62-63.

128 Un asunto diferente es la reforma o "actualización" de los derechos históricos. La estructura autonómica del Estado conduce al planteamiento de la foralidad como eventual limite de la autonomía, de la autonomía como superación integradora o no de la foralidad y en definitiva de la afección categórica de la "actualización" al derecho histórico, de lo que se ocupan Miguel Herrero de Miñón, "Los derechos forales como derechos históricos", en Revista Española de Derecho Constitucional, n. 52 (enero abril 1998), pp. 56-66, 77-80, y Javier Corcuera Atienza, "Notas sobre el debate de los derechos históricos de los territorios forales", op. cit., pp. 76-87. Cuando Miguel Herrero de Miñón, “Los derechos históricos y el principio pacticio”, op. cit., p. 41, se refiere a "las actualizaciones" de los derechos históricos y admite que han de realizarse "mediante normas estatales o autónomas", no se entiende por qué hay que comprenderlas como articulaciones de un pacto que resulta ser "fruto de una coincidencia de voluntades", si no es que la interpretación responde a un irrenunciable prejuicio ideológico. Ante la nueva voluntad política preservadora del derecho histórico, el derecho histórico identificado con la tradición jurídica histórica persistente corre el riesgo de su modificación o disolución, lo que en definitiva demuestra la artificiosidad del concepto. La historia tiende a disolverse tanto si, como dice Bartolomé Clavero, El código y el fuero. De la cuestión regional en la España contemporánea, op. cit., p. 36, "dentro de la constitución y de su desarrollo más consecuente, el complejo foral tiende a 
respecto de cualquier precepto articulado (aun los mismos derechos fundamentales), con mayor motivo habria de serlo respecto del contenido de una disposición adicional. Esto es tan nítido en la técnica constitucional (tan aberrante sería aceptar que la reforma opera ultrarrigida en parte, rígida en parte y en parte flexible) que da la impresión de que Herrero de Miñón lo sabe, y por eso necesita recurrir (de nuevo en el abrevadero de la constitución histórica) a una idea de refuerzo, que resulta ser la noción de pacto. Si cabe utilizar la noción de pacto es porque esta forma parte de los derechos históricos; a Herrero de Miñón no le importa si el pactismo de los derechos históricos fue jurídicamente real o un discurso puramente ideológico ${ }^{129}$ : basta su habilitación en esa expresión esquizofrénica resistente a novaciones. Lo realmente extraño es que una reflexión tan esforzada por tener una coherencia interna como la de Herrero de Miñón se manifieste en este punto radicalmente arbitraria desde el punto de vista jurídico: el pacto - reconoce- cuestiona el "carácter unitario e incondicional, esto es, soberano" del poder constituyente ${ }^{130}$. Por muy razonable que fuera la argumentación hasta este momento (que no lo es), la conclusión es rigurosamente inconstitucional: la soberanía nacional o de todos los ciudadanos no está reconocida en una norma constitucional prescindible, y por cierto que todas las razones aplicadas por Herrero de Miñón al "reconocimiento" de comunidades políticas históricas debería aplicarlas él mismo a la comunidad politica constituyente.

Además, carece de sentido una inclinación estratégica del discurso de Herrero de Miñón que consiste en predicar la potestad constituyente y la legitimación de los derechos históricos de determinadas comunidades regionales, pero no de todas. Cuando Herrero de Miñón dice que los derechos históricos se basan "en la continua conciencia colectiva de la propia identidad diferenciada e infungible que responde a hechos diferenciales objetivos" ${ }^{131}$, aparte de la necesidad de definir qué sea la nebulosa conciencia colectiva, desde luego demuestra, contra su propia intención, que cualquier comunidad está en condiciones de alcanzar dicha identidad, como de hecho ha sucedido en la evolución contemporánea de la ideología nacionalista ${ }^{132}$ y en el proceso de polinacionalización precipitado por la razón constitucional de la identidad histórica incluida en la Constitución de 1978. Es lógico que haya sido así, porque

desaparecer", cuanto si, como dice Fernández, Los derechos históricos, cit., p. 91, la actualización de los derechos forales debe ser, constitucionalmente, "respetuosa con el principio de autonomía de las nacionalidades y regiones".

129 En realidad, Miguel Herrero de Miñón, "Los derechos históricos y el principio pacticio", op. cit., pp. 48-49, no parece conocer la realidad histórica del pactismo como discurso ideológico estamental, y brinda por la historia ficción con dislates jurídicos como la consideración de que príncipe y reino fueron "dos instancias de poder" cuyo acuerdo derivaba en ley paccionada. Para colmo, su idea de pacto no contractual, en pp. 52-53, sino "de unión", aun de desiguales, no es sino un señuelo que, por lo demás, remite a una separación previa, históricamente selectiva y artificiosa.

130 Miguel Herrero de Miñón, Idea de los derechos históricos, op. cit., p. 114.

131 Miguel Herrero de Miñón, “Los derechos históricos y el principio pacticio”, op. cit., p. 39.

132 No es nueva esta tendencia general de expansión nacionalista: para Valencia, Andalucia, Aragón, Canarias, Baleares, Extremadura y Asturias, Manuel Morales Muñoz, "Nacionalismos 'no históricos' y regionalismos en la España de la Restauración, 1874-1931”, en Jean-Louis Guereña y Manuel Morales Muñoz (eds.), Los nacionalismos en la España contemporánea. Ideologías, movimientos y simbolos, Centro de Ediciones de la Diputación de Málaga, Málaga, 2001, pp. 164182. 
esa identidad es bien fácilmente resultado de una inventio, y porque el reconocimiento de estructuras jurídico-políticas, aun en el ámbito global de una concesión estatal, alimenta procesos de poder y la formación de sistemas jurídicos particulares ${ }^{133}$. Contra Herrero de Miñón, lo "artificial" no es solo la "generalización de los Derechos Históricos"134, que ciertamente lo es si se parte de un concepto tan genérico como el de identidad histórica (si se lee estrictamentee, se apreciará la perogrullada de la expresión), sino también la "asimetría" de los derechos históricos, pues cuando toda comunidad acotada tiene una identidad histórica (sea del fuste que sea) y a esa identidad se le imputan derechos, lo artificial es la deshistorización discriminadora de otra determinada entidad. Dicho al revés, lo natural, y nada artificioso, es que si una comunidad politica descubre su historia y se arroga derechos, otra pueda remedar, con análoga razón, el mismo empeño; ni siquiera el menor grado de intensidad en la reclamación política puede ser causa de exclusión o discriminación, porque siempre se está a tiempo, como otro estuvo, de invocar y reclamar la tradición, lo que confirma de hecho tanto lo decimonónico del nacionalismo, cuanto su desenvolvimiento en una foralidad, como la vasca, históricamente de pujanza medieval tardía y obediente a su protección regia (un rey en absoluto pactista) en el campo de una protección del privilegio estamental (hidalguía) ${ }^{135}$. Si no se acepta esta generalización de los derechos históricos, lo que se reclama es sencillamente, como ocurre en el razonamiento de Herrero de Miñón, el privilegio de determinados territorios. Frente a esta evidencia tuvo su razón de ser la decisión política de la estructura autonómica generalizada en la Constitución de 1978136. De ahí que resulte oportuna la comparación de la quimera herreriana

133 Esto explica la debilitación politica, en las reformas estatutarias, del engarce constitucional de la autonomía, y aun de la autonomía entendida en el sentido que explica Francisco L. Pacheco Caballero, "Aportaciones medievales a la noción de autonomía", en Aquilino Iglesia Ferreirós (coord.), Autonomia y soberanía. Una consideración histórica, Marcial Pons, Madrid, 1996, pp. 59-66.

134 Miguel Herrero de Miñón, “Los derechos históricos y el principio pacticio”, op. cit., p. 40.

135 Eduardo Nieto Arizmendiarrieta, "Reflexiones sobre el concepto de derechos históricos", op. cit., pp. 145-147, razona con nitidez cuando explica que, si se quiere certificar una singularidad vasca, la historia no es una condición irrelevante, sino crucial, y considera que "el régimen foral vasco, como sistema indisolublemente unido a la mentalidad jurisdiccional del Antiguo Régimen, entró en crisis cuando éste se vio sustituido por el Estado y los principios liberales", si bien "la debilidad y mediocridad de la revolución liberal española" fue la responsable de "admitir la especialidad jurídico-política vasca", aunque con una "incomprensión del poder central" que explica la "politica reivindicativa del hecho diferencial vasco". Se trata de un planteamiento honrado de la historicidad porque, como dice también Eduardo Nieto Arizmendiarrieta, "La esencia de los derechos históricos", Revista Vasca de Administración Pública, n. ${ }^{\circ}$ 58-1, 2000, p. 215, "Al fin y como se ve, la Historia, de nuevo, como duda central del amparo y respeto de los derechos históricos; y esa Historia, como criterio, esta vez interpretativo, puede originar incertidumbres sobre la posibilidad de deducir una esencia cierta y concreta que, al caracterizar al régimen histórico, deba ser garantizada por la Constitución”. Lo que no queda muy claro — desde el punto de vista de la legitimidad y viabilidad constitucional de los derechos históricos- es si un Estado liberal con fortaleza tendría que haber comprendido mejor el hecho diferencial o simplemente descartarlo por mor del principio de igualdad jurídica.

136 Parece coincidir con Herrero de Miñón y su plan asimétrico José Luis Villacañas Berlanga, Historia del poder politico en España, RBA, Barcelona, 2014, pp. 596-597: "Se alentó a todas las regiones a homogeneizarse en sus órganos y competencias. Así que lo que comenzó siendo un diseño que caminaba hacia un Estado mixto, federal (para Cataluña y, casi confederal, para el País Vasco) y descentralizado (para todas las demás), se encaminó hacia un claro diseño federal homogéneo". Ninguna referencia al embate de este organigrama a la igualdad de los derechos de 
con una interpretación jurídica como la de Jon Arrieta, la cual, adaptada al reconocimiento de los derechos históricos, respeta el espíritu de preservación jerárquica de la cobertura constitucional (propia de la corriente filosófico-jurídica del segundo republicanismo):

La historia, es decir, la trayectoria histórica, la existencia previa sucesiva de unas bases territoriales y sus respectivas instituciones y ordenamientos jurídicos, es la que proporciona la explicación, la razón por la que podemos distinguir los sujetos colectivos que la Constitución incorpora a su texto (nacionalidades, regiones, territorios forales). Que estos entes se encuentren explicados por la historia es suficiente para constatar su preexistencia. [...] La Constitución opta por el reconocimiento y apertura hacia un futuro de consolidación y crecimiento de ciertas 'situaciones jurídicas preexistentes'. [...] Admitir que la Constitución legitima la existencia de nacionalidades, territorios históricos singulares, de derecho civil propio, y comunidades de régimen común, equivale a dar a la Constitución el valor creativo de esa nueva situación, en virtud de la dotación consensuada al texto constitucional de ese valor constituyente de sujetos titulares de derechos. La historia es, sencillamente, anterior a la Constitución, no 'superior' a ella. [...] A mi modo de ver la Constitución, al reconocer Derechos históricos, no procede a un perfeccionamiento clausurante, no se subroga como sustituto de sujetos periclitados y, por lo tanto, no elimina las potencias que los derechos históricos, ahora ya constitucionales, encierran. [...] Que esa personalidad tenga en la historia, como no podía ser menos, su explicación, no significa que la Constitución quede subordinada a aquélla. La historia es, sencillamente, anterior a la Constitución, no 'superior' a ella. ${ }^{137}$

Pero volvamos a la pluralidad constituyente, porque su hallazgo resulta un momento clave de la teoría de Herrero de Miñón. Para salvar el escollo de la soberanía, Herrero de Miñón redefine el poder constituyente, de modo que, contra su entendimiento como una "voluntad unitaria", lo identifica con "la pluralidad y diversidad de los actores constituyentes". Si se acepta por un momento la omisión del reconocimiento constitucional de la soberanía nacional española (una aceptación sin duda excesiva), e incluso si se ignora la diferencia que hay entre la supuesta pluralidad de origen y la unidad cristalizada en la soberanía nacional, todavia hay algo fundamental que falla en el discurso de Herrero de Miñón. Efectivamente, al tener que definir esa pluralidad de actores constituyentes, se refiere a "la Corona, los partidos politicos, los sindicatos, las fuerzas económicas, el Ejército, la Iglesia, los nacionalismos y autonomismos varios que expresa o tácitamente articularon la voluntad constituyente"138. He aquí el tremendo error.

los ciudadanos; llama también la atención la aceptación tácita de la desigualdad jurídica en la hipótesis de un diseño (radicalmente inviable, luego me temo que impensable) de federación o confederación mutilada, esto es reducida a la fracción, lo cual no es otra cosa que el reconocimiento del privilegio; la homogeneidad del diseño "federal" autonómico debería matizarse, también, en cuanto reducido a la estructura formal. Va además implícito en la reflexión el fatalismo típico en la aceptación de los derechos históricos (que no se aplica a los silenciados derechos individuales), característico del pensamiento foralista/nacionalista y de la constitución histórica del transaccionismo elitista liberal-conservador.

137 Jon Arrieta, “Las 'imágenes' de los Derechos históricos: un estado de la cuestión”, op. cit., pp. 250-253.

138 Miguel Herrero de Miñón, Idea de los derechos históricos, op. cit., p. 119. ¿Quiere decir el autor que Ejército, Iglesia, sindicatos, etc., podrian arrogarse derechos históricos pre y para si no supraconstitucionales (no otra cosa es la constitución histórica)? ¿Quiere decir que si la Constitución los reconociera no cabría un juicio de adulteración respecto de la trayectoria 
No es esta la jurídicamente relevante y definitiva pluralidad de actores constituyentes. La jurídicamente relevante y definitiva pluralidad de actores constituyentes son los ciudadanos. Por eso sus derechos fundamentales, en un sistema constitucional tanto liberal como social-democrático de Derecho, constituyen el fundamento del Estado. De los ciudadanos, Herrero de Miñón no se acuerda; y ciertamente puede decirse que los ignora, porque los organismos o instituciones a los que se refiere solo pueden considerarse sustitución de los ciudadanos en un sistema organicista y totalitario. Si la pluralidad de los ciudadanos se percibe como unidad es en función del principio de igualdad jurídica, que horizontaliza el poder de la soberanía en su misma base. Por eso la soberanía de la pluralidad de los ciudadanos (de "todos los ciudadanos", como decía el proyecto constitucional de la I República) aparece fijada como unidad (igualitaria). El pensamiento de Herrero de Miñón ha atravesado el instrumento de la constitución histórica propio del liberalismo moderado y conservador para adentrarse en la perspectiva organicista que fue radicalizada en el anteproyecto constitucional primorriverista y que formó parte también de la concepción del derecho de representación y de asociación en el Nuevo Estado franquista. En su edificio intelectual nada se ha dicho de los derechos individuales, y no es casualidad, porque no habitan alli los ciudadanos.

\section{VISIÓN CONSTITUCIONAL Y ESTATUTARIA DE LOS DERECHOS FUNDAMENTALES.}

Declarada barra libre en la Constitución de 1978 para el ejercicio del "derecho" de autonomía por mor de una identidad o nacionalidad o nación histórica generadora de derechos históricos constitucionalmente reconocidos, no es ninguna casualidad que se haya producido la cosecha continuada y global de esta maquinaria, preestructurada como configuración general políticoadministrativa del Estado en un ámbito lato constituyente. Si se acepta que la normativa constitucional no puede ser internamente jerarquizada, existe una posible disfunción en la equipotencia de los derechos históricos respecto de los derechos fundamentales (antes individuales) que la propia normativa constitucional declara, porque parece evidente que, presupuesto de esta tabula rasa, los derechos fundamentales y en general los principios democráticos tienen que inspirar, desde una superioridad preceptiva y condición sine qua non de validez, tanto las estructuras estatales cuanto las estructuras autonómicas, la materia de la legislación estatal y la materia (derechos históricos o actualización de los mismos) de la legislación autonómica. Se dirá que esto tiene que presumirse así, respecto de las estructuras autonómicas previstas constitucionalmente, tal y como sucede respecto de las estructuras estatales que figuran en el texto constitucional con una normativa del mismo rango que la reguladora de los derechos fundamentales, sin que se discuta su sumisión a tales principios democráticos básicos. Pero la circunstancia de que el reconocimiento de los derechos históricos, con su marchamo por definición preconstitucional (historicidad y preconstitucionalidad excluidas sin embargo, pero no por completo,

axiológica del constitucionalismo (de la misma manera en la que, por ejemplo, no solo es posible sino necesario descubrir, en las totalitarias "leyes fundamentales" del franquismo, la falsedad de su calificación constitucional por falta de los mínimos criterios jurídicos caracterizadores (división de poderes, derechos individuales, etc.) de una verdadera Constitución? 
de las instituciones estatales, contra el conservadurismo constitucional liberal), pueda dar lugar, como de hecho ha ocurrido en cierta doctrina jurídica y en cierta práctica política, a la reclamación de titularidades, legitimidades o fundamentos externos al propio texto constitucional, quizá explica la precaución constitucional de marcar, mediante el desplazamiento de los derechos históricos a la disposición adicional primera, una estructura que si bien no excluya el valor normativo, transmita a su vez que ese valor no puede producirse, extremado, contra la normativa sustantiva de la Constitución.

La reciente historia constitucional española demuestra que esta ocurrencia formal, tan discutida técnicamente, tiene una eficacia muy relativa, no tanto porque en la legislación autonómica se vulneren los derechos fundamentales en su propio ámbito territorial (puesto que, si puede suceder así, no será de manera distinta a como pueda suceder también en la legislación estatal), sino en la medida en la que, mediante la fractura del principio de igualdad jurídica, se vulneren, desde la perspectiva del conjunto, los derechos fundamentales de los ciudadanos del ámbito territorial del Estado en cuanto interno y externo en relación con un determinado ámbito autonómico.

Expresado de otro modo, ¿el reconocimiento de los derechos históricos alcanza, incluso dando por hecho que esté comprobado que formaria parte de su materialidad, a la aceptación de una singularidad o privilegio, de cualquier tipo (no una especialidad), del que no gozan el resto de los ciudadanos, o los derechos históricos están, como el desarrollo de toda la legislación estatal, sujetos al principio constitucional de igualdad jurídica no ya en el ámbito estatutario, sino en todo el ámbito estatal? Es posible que el desarrollo de las identidades históricas pudiera considerarse viable con un reforzamiento paralelo y de la misma intensidad de los derechos fundamentales y en particular del principio de igualdad jurídica, pero la consideración de las estructuras politicas como un diseño a priori parece haber frenado, contra la vocación del Estado constitucional, la aceleración previa y sustantiva de la igualdad de los derechos de los ciudadanos, como si se tratara de la triste riada oligárquica, centralista y regionalista de la historia codificatoria y constitucional española. El hecho de que las estructuras estatales y autonómicas estén sujetas a mecanismos democráticos de producción normativa no implica la evitación de la quiebra de la igualdad jurídica de los derechos individuales o fundamentales de los ciudadanos: recuérdese la desconfianza racionalista hacia cualquier trama de poder. Por lo demás, a diferencia de los derechos históricos, que son derechos colectivos con un grado de desindividualización superior a los derechos sociales 139 , la preexistencia de los derechos individuales no es una preexistencia histórica o existencial, valga la redundancia, sino una preexistencia ontológica (y así no es casualidad que el nacionalismo más radical prescinda al fin también de la historicidad para fundar, en un consentimiento social verdadero, simulado o ficticio, una voluntad politica ontológica pro futuro).

139 Porque, al menos en cierta medida, podría decirse, a la vista de los derechos fundamentales, que los derechos sociales desindividualizadores han podido volver o tender a individualizarse, esto es, a abandonar su perspectiva de clase, en la evolución del Estado liberal al Estado social y democrático de Derecho, bajo la clave axiológica equilibradora del principio de igualdad. Sobre esta cuestión, Ángel Garrorena Morales, El Estado español como Estado social y democrático de Derecho, Tecnos, Madrid, 1987, pp. 37-106. 
Todavía con otras palabras, la polinacionalización encendida por la Constitución de 1978 y su concepción de la autonomía de las identidades históricas, ¿ha llegado al punto de construir, a partir del derecho de autonomia, nuevos campos de cultivo de derechos individuales o fundamentales, con la pretensión de sustituir o desplazar omnino a la Constitución y en consecuencia de excepcionar el principio de igualdad, o este ámbito sigue perteneciendo, con superioridad normativa, a la Constitución? ${ }^{140}$ Porque la imagen popular, no siempre atendida filosóficamente y con todos los matices que se quiera, parece entender que los derechos de los ciudadanos españoles han variado en función de las singularidades autonómicas.

A propósito de los derechos fundamentales, la Constitución de 1978 establece los siguientes principios:

1. ${ }^{\circ}$ Prohibición de privilegios económicos o sociales ${ }^{141}$.

$2 .^{\circ}$ Igualdad de derechos y obligaciones de los españoles en el territorio del Estado ${ }^{142}$.

3. ${ }^{\circ}$ Competencia exclusiva estatal en la regulación de las garantías de la igualdad en el ejercicio de derechos y cumplimiento de deberes constitucionales ${ }^{143}$. públicas $^{144}$.

4. ${ }^{\circ}$ Amparo constitucional de los derechos fundamentales y las libertades

5. Amparo constitucional de los derechos históricos de los territorios forales ${ }^{145}$.

Dejando de lado el valor jurídico de la disposición adicional en el texto constitucional, la prueba del reconocimiento constitucional de un principio supremo de igualdad jurídica como derecho fundamental que informa la

140 Cuando Miguel Herrero de Miñón, "Los derechos forales como derechos históricos", op. cit., p. 54, afirma: "A mi juicio, las antinomias creadas por la irrupción de la historicidad en la normatividad, sólo pueden ser resueltas con mayores dosis de aquélla"; soslaya, en mi opinión, el problema fundamental del ámbito de la formulacion de los derechos individuales o fundamentales, cuya atomización sería una consecuencia de su planteamiento.

141 Constitución de 1978, cit., artículo 138.2: "Las diferencias entre los Estatutos de las distintas Comunidades Autónomas no podrán implicar, en ningún caso, privilegios económicos o sociales".

142 Constitución de 1978, cit., artículo 139: “1. Todos los españoles tienen los mismos derechos y obligaciones en cualquier parte de territorio del Estado. / 2. Ninguna autoridad podrá adoptar medidas que directa o indirectamente obstaculicen la libertad de circulación y establecimiento de las personas y la libre circulación de bienes en todo el territorio español".

143 Constitución de 1978, cit., artículo 149.1: "El Estado tiene competencia exclusiva sobre las siguientes materias: / 1. ${ }^{a}$ La regulación de las condiciones básicas que garanticen la igualdad de todos los españoles en el ejercicio de los derechos y en el cumplimiento de los deberes constitucionales".

144 Constitución de 1978, cit., artículo 161.1: "El Tribunal Constitucional tiene jurisdicción en todo el territorio español y es competente para conocer: (...) b) Del recurso de amparo por violación de los derechos y libertades referidos en el artículo 53,2, de esta Constitución, en los casos y formas que la ley establezca".

145 Constitución de 1978, cit., disposición adicional 1. a: "La Constitución ampara y respeta los derechos históricos de los territorios forales. / La actualización general de dicho régimen foral se llevará a cabo, en su caso, en el marco de la Constitución y de los Estatutos de Autonomía”. 
interpretación de los derechos de los organismos históricos reside en que la Constitución prohíbe a todas las autoridades, estatales o autonómicas, el establecimiento de "privilegios económicos o sociales". La pujanza del privilegio es la consecuencia de la conversión de criterios de especialidad normativa en criterios de singularidad normativa, por desaparición del correlato de la igualdad general; no hay que olvidar que en la Constitución de 1931 la formulación del principio de igualdad jurídica se desarrollaba precisamente como negación de cualquier clase de privilegio ${ }^{146}$. El rechazo del privilegio en la Constitución de 1978 ratifica, en un sentido general o estatal, la primacía del principio de igualdad de derechos y deberes de los españoles "en el territorio del Estado".

Ahora bien, no se cierra así esta problemática, porque lo que podría restar dudoso, una vez admitido que los derechos fundamentales constitucionales no pueden ser subvertidos en el contenido y la actualización autonómica de los derechos históricos, es si, al amparo del reconocimiento constitucional de los derechos históricos, el derecho de autonomía puede incluir, mediante los cauces democráticos constitucionales vertidos en procedimientos estatutarios, una añadida regulación, una regulación propia de los derechos fundamentales, declarativa o al menos interpretativa. Esta posibilidad de que los derechos fundamentales sean absorbidos por el derecho de autonomia tiene que degenerar, casi irremediablemente, en regulaciones diversas y desiguales entre ámbitos autónomicos.

Es cierto que la Constitución parece considerar "competencia exclusiva estatal" la regulación de los derechos fundamentales, pero, si bien se mira, y teniendo en cuenta la fuerza expansiva de los derechos fundamentales, o al menos la necesidad de su interpretación no restrictiva, y jurídicamente no pura ni aislada, sino entreverada en un sinnúmero de cuestiones jurídicas de todo jaez, la competencia estatal exclusiva no afecta a la regulación de tales derechos fundamentales, sino a la "regulación de las garantias" en orden a que se cumpla con el principio de igualdad jurídica (estatal, entre autonomías) al cabo de su regulación. Por lo tanto, el Estado no se arroga la regulación sustantiva omnicomprensiva de los derechos fundamentales, sino la vigilancia por el reequilibrio de la igualdad, mediante la regulación de "garantías", cuando la regulación autonómica que afecte a los derechos fundamentales tome una deriva contraria a aquel principio. Además, la discrecionalidad política es amplia: no hay un deber del Estado (si no el implícito en el cumplimiento del principio de igualdad constitucional), y tampoco hay un deber autonómico, en función del principio de solidaridad, a favor de un contrapeso o de una ponderación cuando las normas estatutarias provoquen esa situación desigual entre los ciudadanos españoles. Y la dejación estatal de una actividad fiscalizadora del derecho autonómico imperativa de oficio para el respeto de los derechos fundamentales se repite, en definitiva, en el amparo de los derechos fundamentales y las libertades públicas por parte del Tribunal Constitucional, una institución que funge de reacción, parche o medicamento, con mayor motivo si ese mismo término de amparo se reproduce (cierto que sin mayores alardes de protección, que habrán de ser, sin embargo, los comunes del recurso de inconstitucionalidad) respecto de

146 Constitución de 1931, cit., artículo 25, párrafo primero: "No podrán ser fundamento de privilegio jurídico: la naturaleza, la filiación, el sexo, la clase social, la riqueza, las ideas políticas ni las creencias religiosas". 
los derechos históricos. Mas así como el amparo de los derechos fundamentales sacrificó su naturalidad por su constitucionalidad, el amparo de los derechos históricos habría de ser no a partir de su condición histórica, sino de su condición de constitucionalidad ${ }^{147}$.

La visión de la materia que ofrecen los Estatutos de Autonomía puede estudiarse diferenciando dos bloques. Un bloque (1) de preservación estrictamente constitucional de derechos fundamentales, donde cabe situar todos aquellos estatutos que excluyen el ámbito autonómico como campo de cultivo de los derechos fundamentales en la medida en la que reconocen que ese campo se sitúa en el ámbito constitucional. Este reconocimiento puede llevarse a cabo de dos maneras, (1.1) con el establecimiento, en los Estatutos de Autonomía, de una remisión a la Constitución en materia de derechos fundamentales, o bien (1.2) con una expresa equiparación, en los Estatutos de Autonomía, entre los ciudadanos de este territorio autónomo y el resto de ciudadanos españoles, en materia de derechos fundamentales. Otro bloque (2) incluye los Estatutos de Autonomía en los que no hay una exclusiva constitucionalización de los derechos fundamentales, (2.1) bien porque a la remisión constitucional se suman instrumentos internacionales, lo cual resultaria la fisura menos agresiva para el sistema jurídico en cuanto la integración de esos instrumentos internacionales está asumida por la propia Constitución (sin perder de vista la bifurcación, no obstante), (2.2) bien porque resultan previstos los derechos actuales como mínimos o la posibilidad de contemplar otros derechos, o bien (2.3) porque los derechos constitucionales aparecen coordinados con la nacionalidad o los derechos históricos.

(1) Estatutos de Autonomía con preservación estrictamente constitucional de los derechos y deberes fundamentales.

(1.1) Mediante remisión constitucional: País Vasco, 1979148; Andalucía, 1981149; Asturias, 1981150; Cantabria, 1981151; Galicia, 1981152; Aragón, 1982 ${ }^{153}$;

147 Tomás Ramón Fernández, Los derechos históricos de los territorios forales. Bases constitucionales y estatutarias de la administración foral vasca, op. cit., p. 85: “[...] basta considerar que la proclamación que se contiene en la disposición adicional primera es, justamento, eso, una adición que, como tal, sólo es pensable de conformidad con el corpus normativo al que se añade. / Por si todo ello no fuera bastante, la proclamación de amparo y respeto de los derechos históricos de los territorios forales, va seguida de inmediato en la propia disposición adicional de un mandato de actualización del régimen foral que esos derechos conforman, actualización que debe producirse necesariamente 'en el marco de la Constitución y los Estatutos de Autonomía'. / La asunción por la Constitución de los derechos históricos de los territorios forales se refiere, pues, al contenido actualizado de los mismos, esto es, al contenido ya depurado y ajustado a los parámetros constitucionales. / Ese acervo histórico, así entendido, se constitucionaliza, es decir, adquiere ahora, por vez primera en la Historia, además, rango constitucional”.

148 Artículo 9.1: "Los derechos y deberes fundamentales de los ciudadanos del País Vasco son los establecidos en la Constitución".

149 Artículo 11: "Los derechos, libertades y deberes fundamentales de los andaluces son los establecidos en la Constitución”.

150 Artículo 9: "Los derechos y deberes fundamentales de los asturianos, son los establecidos en la Constitución".

151 Artículo 5.1: "Los ciudadanos de Cantabria son titulares de los derechos y deberes establecidos en la Constitución". 
Canarias, 1982154; La Rioja, 1982155; Valencia, 1982156; Castilla y León, 1983157; Extremadura, 1983158.

(1.2) Mediante equiparación de todos los españoles: Castilla-La Mancha, 1982159; Navarra, 1982160; Murcia, 1982161; Madrid, 1983162; Ceuta, 1995163; Melilla, $1995^{164}$.

(2) Estatutos de Autonomía sin constitucionalización exclusiva de los derechos y deberes fundamentales.

(2.1) Con remisión bifurcada de los derechos y deberes fundamentales a la Constitución y los instrumentos internacionales: Cataluña, 2006165; Valencia, 2006166; Castilla y León, 2007167; Aragón, $2007^{168}$.

152 Artículo 4.1: "Los derechos, libertades y deberes fundamentales de los gallegos son los establecidos en la Constitución".

153 Artículo 6.1: "Los derechos, libertades y deberes fundamentales de los aragoneses son los establecidos en la Constitución".

154 Artículo 5.1: "Los ciudadanos de Canarias son titulares de los derechos y deberes fundamentales establecidos en la Constitución".

155 Artículo 7.1: "Los ciudadanos de La Rioja son titulares de los derechos y deberes fundamentales establecidos en la Constitución".

156 Artículo 2: "Los derechos, deberes y libertades de los valencianos son los establecidos o reconocidos por la Constitucíon y el presente Estatuto".

157 Artículo 7.1: "Los derechos y libertades fundamentales de los castellano-leoneses son los establecidos en la Constitución".

158 Artículo 6.1: "Los derechos, libertades y deberes fundamentales de los extremeños son los establecidos en la Constitución".

159 Artículo 4.1: "Los derechos, libertades y deberes fundamentales de los ciudadanos de Castilla-La Mancha son los establecidos en la Constitución".

160 Artículo 6: "Los navarros tendrán los mismos derechos, libertades y deberes fundamentales que los demás españoles".

161 Artículo 9.1: "Los derechos y deberes fundamentales de los murcianos son los establecidos en la Constitución para los españoles".

162 Artículo 7.1: "Los ciudadanos de la Comunidad de Madrid son titulares de los derechos y deberes fundamentales establecidos en la Constitución".

163 Artículo 5.1: "Los derechos y deberes fundamentales de los ceutíes son los establecidos en la Constitución".

164 Artículo 5.1: "Los derechos y deberes fundamentales de los melillenses son los establecidos en la Constitución".

165 Artículo 4.1: "Los poderes públicos de Cataluña deben promover el pleno ejercicio de las libertades y los derechos que reconocen el presente Estatuto, la Constitución, la Unión Europea, la Declaración Universal de Derechos Humanos, el Convenio Europeo para la Protección de los Derechos Humanos y los demás tratados y convenios internacionales suscritos por España que reconocen y garantizan los derechos y las libertades fundamentales".

166 Artículo 8.1: "Los valencianos y valencianas, en su condición de ciudadanos españoles y europeos, son titulares de los derechos, deberes y libertades reconocidos en la Constitución Española y en el ordenamiento de la Unión Europea y en los instrumentos internacionales de protección de los derechos humanos, individuales y colectivos, en particular, en la Declaración Universal de Derechos Humanos; en los Pactos Internacionales de Derechos Civiles y Politicos y de Derechos Económicos, Sociales y Culturales; en la Convención Europea de Derechos del Hombre y Libertades Fundamentales, y en la Carta Social Europea". 
(2.2) Con un mínimo o previsión de otros derechos y deberes fundamentales: Andalucia, 2007169; Extremadura, $2011^{170 .}$

(2.3) Con coordinación de los derechos fundamentales y la nacionalidad o los derechos históricos: Cataluña, 1979171, 2006172; Baleares, $1983^{173}$.

En la coordinación de los derechos fundamentales y la nacionalidad y los derechos históricos late una deconstitucionalización, porque a la referencia tácita a la preexistencia de una soberanía alternativa y de unos derechos colectivos se suma, en una digestión completa, la declaración de los derechos fundamentales.

167 Artículo 8.1: "Los ciudadanos de Castilla y León tienen los derechos y deberes establecidos en la Constitución Española, en los Tratados Internacionales sobre Derechos Humanos ratificados por España, en el ordenamiento de la Unión Europea, así como los establecidos en el ámbito de la Comunidad Autónoma por el presente Estatuto de Autonomía”.

168 Artículo 6.1: "Los derechos y libertades de los aragoneses y aragonesas son los reconocidos en la Constitución, los incluidos en la Declaración Universal de Derechos Humanos y en los demás instrumentos internacionales de protección de los mismos suscritos o ratificados por España, así como los establecidos en el ámbito de la Comunidad Autónoma por el presente Estatuto".

169 Artículo 9.1: “Todas las personas en Andalucía gozan como minimo de los derechos reconocidos en la Declaración Universal de Derechos Humanos y demás instrumentos europeos e internacionales de protección de los mismos ratificados por España, en particular en los Pactos Internacionales de Derechos Civiles y Politicos y de Derechos Económicos, Sociales y Culturales; en el Convenio Europeo para la Protección de los Derechos Humanos y de las Libertades Fundamentales y en la Carta Social Europea”.

170 Artículo 6: “1. Los derechos fundamentales de los extremeños son los establecidos en la Constitución. Además, podrán ejercer frente a los poderes públicos regionales aquellos otros derechos contenidos en este Estatuto o en la legislación, especialmente el de participar en los asuntos públicos directamente o por medio de representantes y el de petición. / 2. Para contribuir al bienestar colectivo, son deberes de los extremeños los previstos en la Constitución y en el resto del ordenamiento jurídico".

171 Preámbulo: "La libertad colectiva de Cataluña encuentra en las instituciones de la Generalidad el nexo con una historia de afirmación y respeto de los derechos fundamentales y de las libertades públicas de la persona y de los pueblos [...]". Artículo 8.1: "Los ciudadanos de Cataluña son titulares de los derechos y deberes fundamentales establecidos en la Constitución”.

172 Preámbulo: "La libertad colectiva de Cataluña encuentra en las instituciones de la Generalitat el nexo con una historia de afirmación y respeto de los derechos fundamentales y de las libertades públicas de la persona y de los pueblos [...] El autogobierno de Cataluña se fundamenta en la Constitución, así como en los derechos históricos del pueblo catalán que, en el marco de aquélla, dan origen en este Estatuto al reconocimiento de una posición singular de la Generalitat". Artículo 5: "El autogobierno de Cataluña se fundamenta también en los derechos históricos del pueblo catalán, en sus instituciones seculares y en la tradición jurídica catalana, que el presente Estatuto incorpora y actualiza al amparo del artículo 2, la disposición transitoria segunda y otros preceptos de la Constitución, de los que deriva el reconocimiento de una posición singular de la Generalitat en relación con el derecho civil, la lengua, la cultura, la proyección de éstas en el ámbito educativo, y el sistema institucional en que se organiza la Generalitat".

173 Artículo 9: "Las instituciones de autogobierno, en cumplimiento de las finalidades que les son propias, promoverán la libertad, la justicia, la igualdad y el progreso socioeconómico entre todos los ciudadanos de las islas Baleares, como principios de la Constitución, así como la participación de éstos en la vida política, cultura, económica y social. Inspirarán también en función del poder público en el sentido de consolidar y desarrollar las comunes características de nacionalidad de los pueblos de Mallorca, Menorca, Ibiza y Formentera así como las peculiaridades de cada una de ellas, como vínculo de solidaridad entre todas las islas”. 
La deconstitucionalización se avista mediante la transformación del Estatuto de Autonomía, sucesivamente reformado, en una para o pseudoconstitución ${ }^{174}$.

Todavía no puede decirse que se haya alcanzado en España esta situación jurídica. Pero un futuro de tal cariz alumbra en el ejemplo de pseudorreforma estatutaria que ha ofrecido recientemente la ya citada inconstitucional ley de "actualización de los derechos históricos de Aragón" de 2018. En ella se encuentran no solo los derechos históricos, sino su atribución a una soberanía popular exclusivamente aragonesa, de modo que la afección de los derechos históricos a los derechos fundamentales se produzca ya no respetando la soberanía única de todos los españoles, sino creando una soberanía paralela, por mucho que se utilice el viejo argumento maquillador (recuérdese la posición regionalista en las discusiones parlamentarias de la II República) de que esa soberanía sajada está al servicio de la integración en España ${ }^{175}$. En esta tesitura, se recupera la idea regionalista de pacto (tácitamente, pues, entre soberanias iguales) y se ubica como contenido de los derechos históricos la protección de los derechos sociales ${ }^{176}$. En este sentido, la atribución de las características de los derechos fundamentales a los derechos históricos llega al punto (como si de un remedo a la inversa del iusnaturalismo racionalista se tratara) de mantener que los derechos históricos son preexistentes a la Constitución y al Estatuto de Autonomía ${ }^{177}$, y curiosamente también a la legislación de la Unión Europea (ese

174 Una forma de expresar lo que Bartolomé Clavero, Fueros vascos. Historia en tiempo de Constitución, op. cit., pp. 131-132, explica con estas palabras: "El motivo del derecho histórico se está aplicando [en el Estatuto vasco] primariamente a la Comunidad; la misma medida en que aprovecha a los Territorios Históricos responde ya más a determinación del propio Estatuto que de la Constitución".

175 Ley 8/2018, de 28 de junio, "de actualización de los derechos históricos de Aragón”, cit., artículo 2: "1. Los derechos históricos residen en el pueblo aragonés, del que emanan los poderes de la Comunidad Autónoma de Aragón, y serán amparados y respetados por todos los poderes públicos. / 2. El contenido y efectos de los derechos históricos del pueblo aragonés son los siguientes: a) La expresión de la voluntad del pueblo aragonés de mantener y reafirmar su identidad politica, institucional y jurídica, sin perjuicio de su integración y participación en el Estado español y en la Unión Europea. [...]”.

176 Ley 8/2018, de 28 de junio, “de actualización de los derechos históricos de Aragón”, cit., artículo 2.2: "El contenido y efectos de los derechos históricos del pueblo aragonés son los siguientes: [...] e) Una garantía de los derechos políticos y sociales de los aragoneses, como expresión de los principios tradicionales de libertad, justicia social, igualdad, respeto a la diversidad y pacto". Dada la dificultad técnica de integrar los derechos sociales en los derechos históricos, y la mayor viabilidad de su integración en los derechos individuales, se regatea esta última posibilidad, porque significaria aceptar la primacía de los derechos fundamentales y en consecuencia la de la Constitución, en realidad adaptándola mediante la expresión de "derechos subjetivos", así en el artículo 6.3: "Las instituciones aragonesas garantizarán de forma efectiva el cumplimiento de los derechos sociales que no gozan de una protección legal eficaz, especialmente el derecho al trabajo de calidad, el derecho a una vivienda digna, el derecho a la vida, a la integridad física y psicológica, al asilo y el derecho a unos servicios sociales de calidad. A estos efectos, los citados derechos serán auténticos derechos subjetivos para todos los ciudadanos empadronados en Aragón cuya efectividad podrá ser reclamada de manera directa a la Administración aragonesa en las materias de su competencia. Del mismo modo, los presupuestos de la Comunidad Autónoma de Aragón no podrán en ningún caso reducir los créditos que se hubieran dispuesto para políticas sociales en el ejercicio anterior". Para Miguel Herrero de Miñón, "Los derechos históricos y el principio pacticio", op. cit., p. 39, los derechos históricos no son "subjetivos", pero sí "indisponibles" e "imprescriptibles" como "hecho diferencial objetivo" nacional.

177 Este es el momento para aplicar el afeite que consiste en expresar no una remisión a los derechos y deberes fundamentales constitucionales sino un poder de promoción de garantía y 
medio ya comentado de bifurcación frente a la única ruta constitucional en la determinación de los derechos fundamentales, que ahora se sojuzga), porque los derechos históricos son derechos originarios y no se reducen (inefabilidad natural) a su expresión normativa, amén de su carácter imprescriptible. Por último, los derechos históricos pueden ser "actualizados", no solo por ley, sino también mediante "actos y convenios"178.

La ley autonómica aragonesa demuestra la inercia de las identidades históricas y su gula auto y praeter si no contraconstitucional. Ante esta rara avis legislativa, la prensa puso de manifiesto la sintonía politica entre el nacionalismo, persistente en sus reivindicaciones soberanistas, y la izquierda socialista o comunista, que ha dado en vincular el desarrollo de los derechos sociales al autonomismo polinacionalizador, en una extraña renovación, travestida en izquierda, del conservadurismo liberal (ahora capitalista) transaccionista con el foralismo. Así, la extrema sensibilidad de la Constitución de 1978 hacia el regionalismo ha sido pagada con la traición política regionalista del rechazo recóndito y resurrecto a la asunción de preceptos y limites constitucionales estatales $^{179}$. Siempre por la senda del desprecio descarado hacia el principio de igualdad.

ejercicio de esos derechos. Así en Ley 8/2018, de 28 de junio, "de actualización de los derechos históricos de Aragón", cit., artículo 6: "1. Como sucesores de las instituciones del antiguo Reino de Aragón, los poderes públicos aragoneses promoverán y garantizarán el pleno ejercicio de los derechos y libertades proclamados en el Estatuto de Autonomía, la Constitución española, la legislación de la Unión Europea, la Declaración Universal de Derechos Humanos, el Convenio Europeo para la Protección de los Derechos Humanos, la Carta Europea de las Lenguas Regionales y Minoritarias, la Convención sobre la eliminación de todas las formas de discriminación contra la mujer y el resto de tratados y convenios internacionales que resulten de aplicación, así como aquellos otros derechos que, habiendo sido reconocidos en normas de menor rango jurídico, se encuentren en vigor en el momento de la entrada en vigor de la presente Ley. / 2. Las instituciones aragonesas respetarán y protegerán el contenido actual de los derechos y libertades referidos en el apartado anterior y se opondrán a su minoración o restricción por parte de otras instituciones en cuanto puedan afectar al pueblo aragonés".

178 Ley 8/2018, de 28 de junio, "de actualización de los derechos históricos de Aragón”, cit.. Artículo 3: "2. La actualización de esos derechos históricos impulsará y desarrollará los principios propios del Estado social y democrático de Derecho, así como el cumplimiento de los derechos y libertades de los aragoneses, y se llevará a cabo atendiendo a la realidad social, cultural, económica y política del momento actual. / 3. Los derechos históricos originarios de Aragón se podrán actualizar mediante ley, actos y convenios, entre otros, en el marco de la Constitución española y el Estatuto de Autonomía. / 4. Los derechos históricos referidos en esta ley no agotan la relación y actualización de los mismos. En especial, la Comunidad Autónoma de Aragón se reserva el derecho de requerir un régimen financiero propio y una Hacienda foral, al amparo de lo previsto en la disposición adicional primera de la Constitución". Artículo 4: "1. Los derechos históricos del pueblo aragonés son anteriores a la Constitución española y al Estatuto de Autonomía, que los amparan y respetan, así como a la legislación emanada de la Unión Europea. Al no emanar de ellos, han de ser respetados por las reformas que puedan afectar a esas normas. / 2. Los derechos históricos no prescriben por falta de uso, ejercicio o reclamación".

179 En cualquier caso, la reforma constitucional es rígida de ninguna manera siguiendo "la vieja pulsión de 'atado y bien atado', que como es sabido era más vieja que Franco", como dice José Luis Villacañas Berlanga, Historia del poder politico en España, op. cit., p. 597, sino conforme al principio técnico de rigidez propio de las constituciones progresistas, que tiene como fin preservar el resultado normativo del consentimiento ciudadano soberano (tan difícil de conseguir $\mathrm{y}$ asentar) en cuanto núcleo global igual constituyente, frente a los advenidos intereses y ocurrencias temporales (parciales y a menudo sin efervescencia popular) de las oligarquias de derecha o izquierda, no en vano las constituciones moderadas o conservadoras, elaboradas y 
A punto de terminar estas páginas, el pronóstico de una tendencia estatutaria paraconstitucional, por la vía de la absorción de los derechos fundamentales (en una versión regionalizada que contrasta con su declaración constitucional general, e igual respecto de la generalidad), se confirma en la reforma del Estatuto de Autonomía de Canarias de 2018. En su título primero aparece, como nunca había ocurrido, una relación extensísima de "derechos, deberes y libertades", sumados a los que contemplan la Constitución y los instrumentos internacionales (convirtiendo todos estos últimos, por lo tanto, en un minimo). Además, es muy llamativo que los derechos estatutarios sean atribuidos a quienes tienen "la condición política de canarios" (nótese que no jurídica, luego con un margen de discrecionalidad) y que su extensión "a otras personas", lo que habrá de incluir al resto de españoles, se considere potestativa, no imperativa. La regionalización es transparente ${ }^{180}$, y nada queda reducida por la exclusión de restricciones de los derechos constitucionales en virtud de los derechos estatutarios (tampoco se concreta si respecto de los ciudadanos canarios o de los ciudadanos españoles en general) ${ }^{181}$. Es más, el principio de igualdad, que precede significativamente al título primero (en reconocimiento de su presidencia de los derechos fundamentales), está planteado en una desuniversalizadora manifestación canaria, desindividualizándolo como derecho por mor de su regionalización, y desindividualizándolo además en virtud de los derechos sociales, al quererlo hacer compatible con la discriminación positiva de "sectores, grupos o personas" ("desfavorecidas", al antojo político) ${ }^{182}$. A partir de aquí, el Estatuto expectora y catapulta una marabunta de derechos ${ }^{183}$, en los que

sostenidas por la oligarquía, optaron siempre por ser técnicamente flexibles, y así sumisas a los ajustes reformistas de los intereses coyunturales de las fuerzas sociopolíticas, económicas, etc.

180 Ley Orgánica 1/2018, de 5 de noviembre, cit., artículo 9: “1. Las personas que ostentan la condición política de canarios son titulares de los derechos, deberes y libertades reconocidos en la Constitución española y en el presente Estatuto, así como en el Derecho de la Unión Europea y en los instrumentos internacionales de protección de los derechos humanos, individuales y colectivos, en particular, en la Declaración Universal de Derechos Humanos. / 2. Los derechos reconocidos en el presente Estatuto se podrán extender a otras personas, en los términos que establezcan las leyes".

181 Ley Orgánica 1/2018, de 5 de noviembre, cit., artículo 10.1: "Ninguna de las disposiciones de este título puede ser desarrollada, aplicada o interpretada de forma que reduzca o limite los derechos fundamentales reconocidos por la Constitución y por los tratados y convenios internacionales ratificados por el Estado español".

182 Ley Orgánica 1/2018, de 5 de noviembre, cit., artículo 11: “1. Los poderes públicos canarios garantizarán las medidas necesarias para hacer efectivos los derechos de las personas a la igualdad, la no discriminación, la participación en la vida pública, al desarrollo económico, la libertad y el respeto a los derechos humanos. / 2. Los poderes públicos garantizarán el derecho a la igualdad de trato y a la no discriminación por razones de sexo, género, nacimiento, etnicidad, ideas políticas y religiosas, edad, discapacidad, orientación o identidad sexual, enfermedad, lengua o cualquier otra condición o circunstancia personal o social. La prohibición de discriminación no impedirá acciones positivas en beneficio de sectores, grupos o personas desfavorecidas".

183 Ley Orgánica 1/2018, de 5 de noviembre, cit., artículos 12-35: "derecho a la protección social, jurídica y económica para atender a las situaciones familiares", "derechos de las personas menores de edad", "derechos de las personas jóvenes", "derechos de las personas mayores", "derechos de las personas en situación de discapacidad y de dependencia", "derecho a la igualdad entre mujeres y hombres", "derecho a la orientación sexual", "derechos en el ámbito de la salud", "derecho a formular instrucciones previas", "derechos en el ámbito de la educación", "derecho de acceso a la vivienda", "derechos en el ámbito laboral y profesional", "derecho a una renta de ciudadania", "derechos de consumidores y usuarios", "derechos en el ámbito del medio ambiente", 
destaca la influencia de los derechos sociales, pero además la formulación de derechos que podriamos considerar ya no solo desindividualizados, ni desnaturalizados en virtud de su constitucionalización o cobertura estatutaria o legal, sino incluso, y aprovechando precisamente la operación de su plasma estatutario, contranaturales, como ese indescifrable derecho a la "memoria histórica" que ni siquiera es derecho sino potencia natural de la mente humana (salvo carga política ideológica retroactiva ${ }^{184}$ ), o esos derechos de unos animales que no tienen la capacidad natural (titulares objetivos, al modo medieval, y sin embargo no responsables) ni de reconocerlos ni de ejercerlos ni de reclamarlos. La imaginación no corre del lado de la profundización en los medios de reconocer y proteger los derechos individuales frente al poder, por razón de su naturaleza igual, sino que la sumisión a la legalidad y su voluntad politica se ha convertido, como era de temer, ya no solo en un limite de aquellos, sino en el cauce para la

\footnotetext{
"derechos en el ámbito cultural", "derecho de acceso a las tecnologias de la información y de la comunicación", "derechos en el ámbito de los servicios sociales", "derecho a la protección de los datos personales", "derechos de participación", "derecho a una buena administración", "derechos en el ámbito de la justicia", "derecho a la memoria histórica", "derechos de los animales".
}

184 Ley Orgánica 1/2018, de 5 de noviembre, cit., artículo 34: “1. Los poderes públicos canarios velarán por el conocimiento y el mantenimiento de la memoria histórica de Canarias como patrimonio colectivo que atestigua la defensa de la identidad y la cultura del pueblo canario y la resistencia y la lucha por los derechos y las libertades democráticas. A tal fin, deberán adoptar las iniciativas institucionales necesarias para el reconocimiento y la rehabilitación de todos los ciudadanos que han sufrido persecución como consecuencia de la defensa de su identidad cultural, de la democracia y del autogobierno de Canarias. / Los poderes públicos canarios deben velar para que la memoria histórica se convierta en símbolo permanente de identidad, multiculturalidad, tolerancia, de dignidad de los valores democráticos, de rechazo de los totalitarismos y de reconocimiento de todas aquellas personas que han sufrido persecución debido a sus opciones personales, ideológicas o de conciencia". Obviamente, la "reparación", que puede muy bien, siempre sin discriminaciones ideológicas (bajo el principio de igualdad), considerarse un deber del poder público, plantea dificultades cuando pretende formularse como un nuevo derecho frente al poder público, porque incluye antinomias, que se acentúan cuando la idea perfilada tiene función retroactiva. La ideología puede imponerse entonces al derecho individual de reparación: ¿'solo merece reparación el que ha sufrido persecución o represión por la defensa de un sistema democrático pero no el que ha sufrido una persecución o represión exactamente igual por la defensa de un sistema totalitario? ¿Quién decide el grado de democracia de cada sistema defendido? ¿Quién lo decide, una vez más, teniendo en cuenta los problemas añadidos de interpretación histórica, lo que incluye no solo episodios de masas sino también la situación y condicionamientos personales de cada individuo inmerso en un proceso histórico colectivo, en el que puede carecer de libertad para posicionarse? Tratándose de totalitarismos, parece sencillo defender la reparación del perseguido, pero en el caso de la persecución por defensa de la identidad cultural, ¿se considerará persecución la política activa contra identidades culturales que incluyen la discriminación politica, religiosa, sexual, contra los propios derechos individuales en general, constitucionales, y aun estatutarios en particular? Y, en el caso de la defensa del autogobierno de Canarias, ¿verdaderamente puede considerarse que una estructura administrativa de fundamento estatal (asî lo reconoce la reforma estatutaria en el artículo 1.2) es un principio ideológico que merece discriminación positiva frente a eventuales medidas en su contra si legalmente válidas y constitucionalmente legitimas? Porque el problema de la combinatoria de derecho y deber está en que el derecho atribuido a un sujeto se considere deber a respetar por otro, de manera que la defensa del autogobierno se juzgue territorio inmune que impida, para no caer en la represión, el derecho fundamental de la libertad de opinión política. Todas estas cuestiones ponen de manifiesto la dificultad de la teoría de los derechos individuales, máxime si expansiva, que desde luego no debe obedecer a la improvisación politico-ideológica ni tiene como ámbito de desarrollo un espacio regional, sino que merece una reflexión filosóficojurídica y el espacio general e igual ciudadano estatal. 
construcción colectiva y determinista (con una fatalidad similar a la de los derechos históricos) del catálogo y la esencia misma de los derechos.

Sorprendentemente, ante una Constitución que se retuerce a sí misma hasta el trauma, en el intento de incorporar al regionalismo foralista $y$ nacionalista sin menoscabo del principio de igualdad y de la protección de los derechos fundamentales, con el riesgo de autolesionarse, el fatalismo en la asunción doctrinal de los derechos históricos ha deslumbrado hasta apagar la teoría de la comunión igualitaria de los ciudadanos - tiempo perdido- porque los ciudadanos otros, en la polinacionalización, parece que son otros estados, otros espacios o sea la superficie contra la que se necesita contrastar la singularidad del privilegio, esa antigua querencia oligárquica. Lo que en definitiva supone la reproducción de la tradicional traba sociopolitica española a la unidad de códigos y de fuero ${ }^{185}$, o la sempiterna resistencia española a la filosofía igualitaria del racionalismo.

La interpretación de los derechos históricos como obstáculo a la arquitectura del Estado constitucional en España formaba parte del análisis de Bartolomé Clavero, que después, sin embargo, ha dicho:

Requisito del derecho individual es el derecho colectivo. Legitimación del derecho colectivo es el derecho individual. La predicación es mutua. El redondeo puede producirse; el círculo, cuadrar. No hay derechos individuales sin derechos colectivos, como tampoco debe haber, tampoco cabe admitir, lo segundo sin lo primero. La afirmación de los derechos individuales negándose los colectivos ha sido históricamente fórmula para mantenerse el colonialismo y otros modos de opresión o discriminación entre pueblos. La posición contraria, la que afirma derechos colectivos ignorando los individuales, sacrifica también humanidad. 186

Creo que Clavero confunde derechos colectivos con principio de igualdad. El derecho individual sujeto al derecho colectivo reenvía al privilegio, al estamento, no en vano la concepción normativa de la monarquía absoluta fue circular, y para la cuadratura habría que romper el círculo, que no era giratorio sino jerárquico, con eje. Obviamente, el problema reside en la legitimidad del sujeto colectivo, pero si este sujeto colectivo no se exige predeterminadamente de origen individual, lo que incluiria el problema de su extensión (no ya para la construcción desde abajo de una titularidad, sino para el respeto hacia una deconstrucción eventual también desde el individuo, esto es, el problema de la resistencia del individuo a la nueva colectivización clasista o nacional), solo genera o fuerza un ámbito desigual. Clavero acepta la existencia de un sujeto colectivo histórico donde puede no estar formado realmente porque, si no lo hace, sabe que quiebra la razón de igualdad: si acepto un sujeto colectivo regional que ha ganado una titularidad puedo cumplir formalmente con la igualdad del colectivo sumiso al tiempo que evito a los sujetos individuales insumisos del colectivo estatal desagregado (que tiene también sus razones de legitimidad) y evito a los sujetos individuales que, expulsados como excepciones irrelevantes,

185 La presunción de centralización político-administrativa en el Estado constitucional también se confunde con el principio de igualdad jurídica, cuando no tiene una relación necesaria.

186 Bartolomé Clavero, “Derechos humanos (individuales) y Derechos históricos (colectivos)", en Miguel Herrero de Miñón y Ernest Lluch (eds.), Derechos históricos y constitucionalismo útil, Crítica, Barcelona, 2001, p. 117. 
niegan su voluntad desde dentro a la desagregación. Pero ya Ortega y Gasset (cuestión catalana) puso en duda esa realidad social uniforme, y su diversidad ideológica persiste hoy, en una separación poco desproporcionada y extrañamente ignorada en su profundidad por los analistas (politicos, jurídicos y filosóficos), o sin consecuencia ninguna en sus reflexiones, de modo que la voluntad regional no ejercería una consumada titularidad colectiva (que se arroga un derecho) sino que simplemente lograría, en el juego de fuerzas politicas, la imposición de una supremacía colectiva sobre otra (la cual, en su sometimiento, a su vez resulta forzada a colectivizarse porque, si queda en individual, viene a ser fácilmente despreciada y arrasada).

El derecho colectivo no atiende a las razones de los derechos individuales y no puede respetarlos a priori, por lo tanto no se legitima en estos, como estos no pueden legitimarse, aunque a primera vista pareciera sencillo (democracia institucional mediante), en él. He aquí la enseñanza de la primera vocación iusracionalista, con desconfianza a toda estructura de poder, por mucho que parezca monolíticamente pacífica y legitimada desde el punto de vista político y social. En el colonialismo, al que se refiere Clavero, la legitimidad de la autodeterminación o independencia no está basada en ningún derecho colectivo, ni menos aún en ningún derecho individual (que, por supuesto, no se garantiza), sino en la ilegitimidad política del dominio impuesto para la recuperación o articulación de un nuevo (tras invadido) dominio. Es rara, en la tesitura de estas páginas, esta formulación de un nuevo derecho nacional (colonial). De manera que, tal vez, sea conveniente evitar la agregación de nuevos elementos, porque del aquelarre se alimenta la ceremonia de la confusión. Ensayada la desaparición del individuo, en el pensamiento totalitario, el colectivismo conduce al organicismo, y nada tiene que ver con aquello que propugnan, contra el egoísmo individualista, algunos poetas herméticos: la confusión en el otro.

Enviado el (Submission Date): 26/10/2020

Aceptado el (Acceptance Date): 18/12/2020 